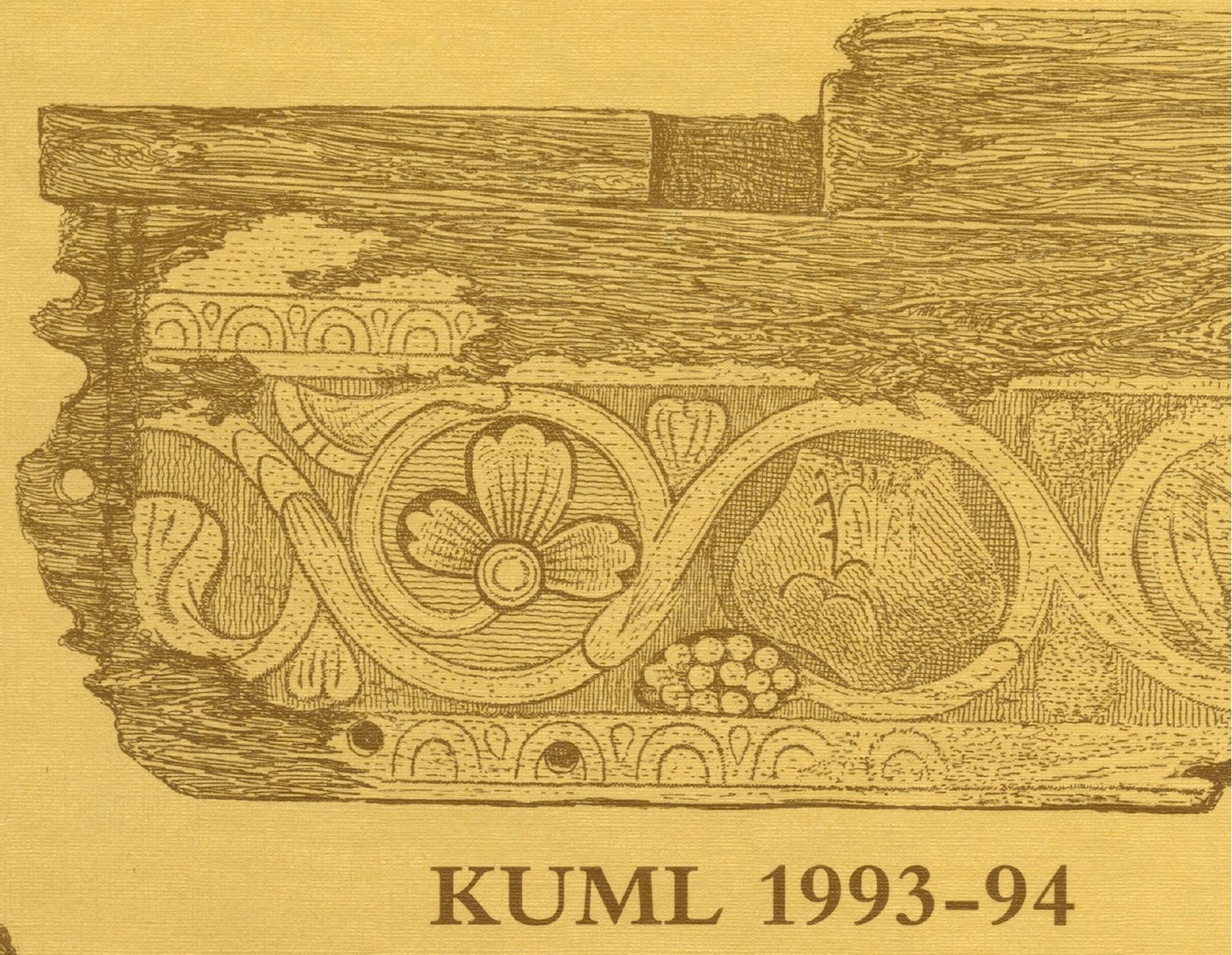




\section{KUML 1993-94}

Årbog for Jysk Arkæologisk Selskab

With summaries in English 
Redaktion: Hans Jorgen Madsen, Poul Kjarum og Birgit M. Rasmussen

Redaktionsudvalg:

Steen W. Andersen, Haderslev

Jens Henrik Bech, Thisted

Steen Hvass, Vejle

Stig Jensen, Ribe

Erik Johansen, Aalborg

Carsten Paludan-Müller, Randers

Ole Schiorring, Horsens

Lay-out og omslag: Jørgen Mührmann-Lund

Grafisk tilrettelagggelse: Elsebet Morville

Tryk: Narayana Press

Skrift: Bembo 11/12

Papir: $115 \mathrm{~g}$ Artik Silk

Copyright 1996 by Jysk Arkaologisk Selskab

ISBN 87-7288-585-8

ISSN 0454-6245 


\section{Indhold/Contents}

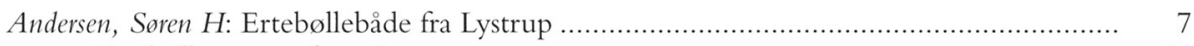

Ertebølle canoes from Lystrup ....................................................................... 36

Ebbesen, Klaus: En jættestue ved Fjersted, Sydvestjylland......................................... 39

A Passage Grave at Fjersted, SW Jutland ................................................... 85

Hansen, Mogens: Træbyggede gravkister fra Enkeltgravskulturen og Senneolitikum ........... 87

Wooden burial cists from the Single Grave Culture and the Late Neolithic .............. 145

Nilsson, Torben: Store Tyrrestrup

En vendsysselsk storgård med bronzedepot fra ældre bronzealder............................ 147

Store Tyrrestrup. A large Early Bronze Age farmstead with bronze hoard .............. 153

Anne-Lonise Haack Olsen og Jens-Henrik Bech. Med bidrag af Svend Th. Andersen,

Pia Bennike, Kjeld Christensen og David Earle Robinson: Damsgård

En overpløjet høj fra ældre bronzealder per. III med stenkiste og ligbrændings-

grube .....

Damsgård. A ploughed-over barrow from Early Bronze Age Per. III with

stone cist and pyre-pit.

Aase Gyldion Andersen: Frugtbarhedsofringer i Sydvestfyns ældre jernalder

Private eller kollektive ofringer?

Fertility Sacrifices in the Early Iron Age of SW Funen. - Private or Collective?..... 210

Torben Egeberg Hansen: Et jernalderhus med drikkeglas i Dejbjerg, Vestjylland .................. 211

Drinking Glasses from an Iron Age settlement from Dejbjerg, West Jutland.............. 237

Mette Iversen og Bjarne H. Nielsen: Brandstrup III.................................................... 239

Grave fra yngre romersk jernalder

Brandstrup III. Graves from the Late Roman Iron Age...................................... 250

Anne Hedeager Krag: Smykkefundet fra Lerchenborg ............................................. 251

Østlige forbindelser i vikingetid

The Lerchenborg Ornaments. Eastern connections in the Viking Age ................ 261

Jens Jeppesen og Holger Schmidt: Rekonstruktion af stavkirken fra Hørning ....................... 263

The reconstruction of the stave church at Hørning ............................................... 275

Bruno Frohlich, Henrik Hjalgrim, Judith Littleton, Niels Lynnerup og Birgitte Sejrsen:

Skeletfundene fra Skt. Peders sognekirkegård i Randers ......................................... 277

Skeletal remains from St. Peder's parish church in Randers .................................. 287

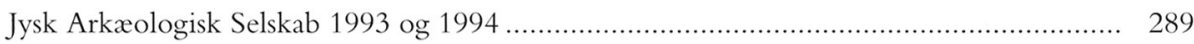




\title{
Træbyggede gravkister fra Enkeltgravskulturen og Senneolitikum
}

\author{
Af Mogens Hansen
}

For mere end 50 år siden fremlagde P.V. Glob (1944) i sin afhandling "Studier over den jyske Enkeltgravskultur« for første gang en træbygget gravkiste, som dermed føjede sig til endnu en af de talrige kendte gravtyper fra enkeltgravskulturen og senneolitikum.

Denne gravtype var i flere årtier herefter yderst sjælden. Derfor er det også forståeligt, at den kun har været sporadisk behandlet i litteraturen (Hansen \& Rostholm 1993, $119 \mathrm{ff}$ med henvisninger). Siden slutningen af 1970'erne er antallet dog blevet mangedoblet og er i dag oppe på 29, hvortil kommer 9 usikre eller ubestemmelige (1).

De mange nye fund giver en mulighed for en systematisk analyse af gravtypen, dens konstruktion, funktion og kronologi. Gravtypen knytter sig tæet til de stenbyggede gravkister, hvoraf der kendes 162 eksemplarer. Heraf er de 93 så velbevarede, at de kan typebestemmes.

Materialet er derfor så stort, at en samlet fremlæggelse af de træbyggede gravkister og en nyvurdering, der også inddrager de samtidige og nærtstående stenbyggede gravkister, kan kaste nyt lys over enkeltgravstidens og senneolitikums gravskik. Ikke mindst giver den typologiske analyse grundlaget for en mere præcis datering af de enkelte gravkister inden for perioderne og et bedre udgangspunkt for en forståelse af baggrunden for gravtypens opståen og udvikling.

Efter en kort redegørelse for periodens gravformer foretages en gennemgang af de stenbyggede gravkisters forskningshistorie og de problemstillinger, der knytter sig til deres datering, oprindelse og udvikling. Derefter vil 11 udvalgte træbyggede gravkister blive mere detaljeret beskrevet, og deres konstruktion og anvendelsesmåde vil blive vurderet på grundlag af samtlige fund af træbyggede gravkister. Der vil blive foretaget en typologisk analyse af alle de velbevarede gravkister.

Derefter vil der blive foretaget en sammenligning med udenlandske fund af træbyggede gravkister, og en teori om deres oprindelse og udvikling vil blive fremsat. Til sidst vil der blive foretaget en sammenligning med de få kendte hustomter, der antyder en paralleludvikling mellem de to anlægstyper. 


\section{Grave fra Enkeltgravskulturen og Senneolitikum}

Enkeltgravskulturens og senneolitikums grave falder i to kategorier: lukkede grave og åbne grave. De lukkede grave kan opdeles i to hovedgrupper: 1) Enkeltgrave, dvs. bulkister, plankekister og lukkede, op til mandslange stenkister af forskellige typer (Sterum 1974, 61), dækket af høj eller måske i sjældne tilfælde under flad mark. 2) Lukkede kamre. Heri kan være begravet en eller flere personer. Men kammeret er ikke beregnet til aktiviteter, der kræver fornyet adgang til kammeret som f.eks. genanvendelse. I disse kamre er der ofte anbragt kister i form af bulkister eller plankekister.

De ældste lukkede kamre - fra ældre undergravstid - ses som små ringgrøfter eller cirkelgrave, ofte med stolpehuller eller plankespor. Kamrene har formentlig været bikube-formede. Typen kendes i et større antal fra Syd-, Midt- og Vestjylland samt Fyn og Holland (f.eks. Glob 1944, 170ff; Lauenborg 1980, 7 ff; Rostholm 1977, 101ff; 1982b; Neumann 1963; Andersen 1978, 7; Van Giffen 1930; Lanting \& van der Waals 1976, 47ff).

Større rektangulære lukkede kamre fra ældre bundgravstid kendes fra Gårslev (Hvass 1990). Et fund fra Lundgård (IB.04) fra yngre bundgravstid er muligvis også et lukket anlæg. Fra overgravstid kendes et kammer fra Edderup (2). Et lille ovalt trækammer fra Tvillinghøjgård (3) kan muligvis også være lukket. Det dateres til senneolitikum A. Et fund fra Hjordkær kan dateres til senneolitikum C (Jørgensen 1985, 155).

To anlæg har haft et rektangulært, teltformet kammer uden spor af indgang, nemlig Gantrup fra ældre bundgravstid (Madsen 1990a, 77ff) og Stendis fra yngre bundgravstid (Olesen AUD 1986/429). Beslægtede anlæg kendes også fra Skåne (Larsson 1987).

Ved et stort anlæg fra Diverhøj fra senneolitikum A er det ikke muligt at afgøre, om der har været indgang eller ej (Asingh 1988).

De lukkede kammergrave optræder således fra enkeltgravskulturens tidligste fase, op gennem senneolitikum op i ældre bronzealder (Neumann 1963, 28ff; Madsen 1990).

De åbne grave falder ligeledes i to hovedgrupper: 1) Genanvendte megalitgrave. Sekundært anvendte megalitgravene er antagelig den mest almindelige gravform uden for Vestjylland fra både enkeltgravskultur og senneolitikum. En nærmere behandling ligger uden for rammerne af nærværende arbejde. 2) Gravkister. Gravkisterne præsenteres i katalogerne og en række upublicerede træbyggede anlæg fremlægges i det følgende kapitel.

De åbne grave anvendes sporadisk fra yngre undergravstid. Men fra bundgravstid og op i senneolitikum bliver de meget almindelige. Det er ovenfor nævnt, at der i næsten hele perioden er en klar kronologisk parallelitet mellem de mange forskellige gravtyper. Det er derfor nærliggende at se forskellighederne i begravelserne som udtryk for forskel i status mellem de levende, men hvordan forholdet end er, må gravformer afspejle forskellige ideer omkring døden, og håndteringen af de døde. Det at bygge eller anvende grave, der giver mulighed for en senere adgang til gravkammeret må være udtryk for en helt anden tankegang, end den der ligger bag de lukkede grave. 


\section{Forskningshistorie}

En træbygget gravkiste fra enkeltgravstiden blev, som tidligere nævnt først erkendt af P.V. Glob i 1944, hvor han i afhandlingen om enkeltgravskulturen fremlægger graven fra Kjeldagerhøj (Kat.IA.19). Glob gør opmærksom på, at gravtypen, bortset fra byggematerialet, svarer til de stenbyggede gravkister. Således fremhæver han, at graven fra Kjeldagerhøj og gravkisten (af sten) fra Katbjerg (Kat.IIA.59) er af nærmest identisk form.

Siden er de træbyggede gravkister kun sporadisk behandlet i litteraturen. Der er dog fremlagt 8 sikre fund, men i ingen af tilfældene har forfatterne fundet grundlag for videregående slutninger (Kat.IA.14, 16, 17, 19, 20, 22, 27 og 28).

De stenbyggede gravkister blev første gang udskilt som en særlig gravtype i 1881 (Pedersen 1881, 331-32) og omtales kortfattet et par gange de følgende år (Bahnson 1892, 179 f og Müller 1897, 195).

I 1902 defineres typen mere præcist af Müller. Han definerer gravkister som kister med indgang. Desuden fremhæves forskellen mellem dem, han benævner »de egentlige Gravkister« (de sjællandske) og »De jyske Gravkister«.

De sjællandske er $\varnothing-\mathrm{V}$-orienterede, smalle og godt mandslange stenkister med adgang fra den ene gavl. De dateres til senneolitikum og overvejende denne periodes yngre del. De jyske gravkister beskrives som N-S-orienterede, bredere, længere og med åbning eller kort gang mod syd. De dateres til enkeltgravstiden og tidlig senneolitikum. På grund af formmæssige ligheder med nogle jyske jættestuer foreslår Müller en ubrudt udviklingsrække fra jættestuer til gravkister i landsdelen. Gravkisterne med forrum anses for at være ældst, mindre kister med rudimentær gang er yngre, mens kister blot med tærskel- eller dørsten er yngst.

Denne afledning fra tragtbægerkulturens megalitgrave opretholdes, men udbygges og nuanceres af forskellige forskere de følgende år, hvor også en række nye fund fremlægges (Kjær 1910, 169-238; Müller 1911, 291-304; Müller 1913, 192-195; Rosenberg 1929, 261; Nordmann 1935).

I 1936 tilbageviser Forssander den direkte forbindelse til tragtbægerkulturens megalitgrave, idet han påviser, at gravkisterne i Jylland - "megalitgravkisterne», som han kalder dem - gennem fundmaterialet kun kan knyttes til den sene enkeltgravskultur og senneolitikum (Forssander 1936, 114 og 138) (4). Med hensyn til gravkisternes oprindelse er Forssander forsigtig. Han nævner dog muligheden for, at de kan være opstået »fordi Enkeltgravsfolkene ved deres Fremtrængen til Øst- og Nordjylland har foretaget Begravelser i Tragtbægerkulturens Megalitgrave, og derigennem er blevet inspireret til selv at bygge Megalitgrave« (Forssander 1936, 115).

I en række senere arbejder afleder Becker, Brøndsted og Glob de jyske gravkister fra $\varnothing$-danske gravformer, Oderkulturens stengrave eller andre samtidige kistetyper fra det nordlige Mellemeuropa (Becker 1936, 226; Brøndsted 1939, 278 ; Brøndsted 1939, 278; Glob 1944, 200; Brøndsted 1957, 315).

Glob behandler i stor udstrækning de jyske gravkister som én gravtype. Han tager udgangspunkt $i$ det daterende gravgods, mens selve gravens udformning kun behandles perifert. Glob går imod Müllers tidligere synspunkter om typens udvikling og anfører - dog uden nærmere argumentation - at de pæreformede 
er de ældste, mens kister med rektangulær grundplan er yngre (Glob 1944, 195). Et synspunkt, der i det følgende kan bekræftes.

Lomborg opdeler i 1973 alle stenkister i to store, formmæssigt, heterogene grupper: 1) stenkister fra enkeltgravskulturen og 2) stenkister fra senneolitikum. Også hos Lomborg er udgangspunktet det daterende gravgods og ikke gravenes udformning. Lomborg mener, at de nordjyske gravkister kun er opført i mellemneolitikum, mens de senneolitiske repræsenterer andre traditioner, inspireret fra Vesteuropa (Lomborg 1973, 121ff).

Senest har Ebbesen (1985) publiceret en større artikel om gravkisterne med en omhyggelig fremlæggelse af 65 grave. Han inddrager udtrykkelig ikke alle gravkister med indgang, men kun dem der falder ind under begrebet »Bøstrupkister", der omtrent defineres som Müllers "jyske gravkister". De mange andre variationer af gravkisterne behandles således ikke, og der forsøges ingen yderligere typologisk opdeling af gravene.

Ebbesen mener at kistetypen "..er opstået i Nordjylland, ikke som et isoleret fænomen, men som led i en generel europæisk udvikling (Ebbesen 1985,42). Typen kan føres tilbage til enkeltgravskulturens bundgravstid, mens en fortsat opførelse i senneolitikum stadig betragtes som et åbent spørgsmål, men "En placering i et dolktidsmiljø er derfor ingenlunde usandsynligt« (Ebbesen 1985, 41). Dette er en modification af samme forfatters tidligere synspunkt, hvor en fortsat opførelse i senneolitikum anses for sikker (Ebbesen 1980, 156 note 3) (5).

De sjællandske gravkister er behandlet af Liversage (1964) og senest af Schiellerup (1992). Begge tager udgangspunkt i Müllers definition af typen. Liversage bemærker dog de store formmæssige variationer og ligheder med nogle af de jyske gravkister (Liversage 1964, 49f).

\section{Problemstillingen}

Problemerne om gravkisternes typologiske variationer, kronologi og oprindelse er således stadig uløste. En årsag kan være, at alle arkæologer hidtil har følt sig stærkt bundet af Müllers definition af de jyske gravkister, hvor kammerets pæreform og N-S-orienteringen er de centrale karakteristika. Herved udelukkes en større gruppe gravkister, hvor kun formen og/eller orienteringen er afvigende (6), men skal problemerne omkring gravkisterne analyseres, må hele materialet af gravkister fra enkeltgravstiden og senneolitikum inddrages.

Et andet problem er den usikre kronologi, der skyldes, at det har været vanskeligt at udskille netop de typologiske elementer, der er kronologisk betingede. Mange stenbyggede gravkister har været anvendt til gentagne begravelser, og der er sandsynligvis foretaget udrømninger af ældre gravgods $\mathrm{i}$ forbindelse med mange af de sekundære begravelser (7). Ligeledes har moderne forstyrrelser i en lang række tilfælde medført fjernelse af oldsager. Derfor kan man meget sjældent, ud fra det fundne gravgods i de stenbyggede gravkister, sige noget sikkert om, hvornår de forskellige gravkister er anlagt. Ud fra de ældste oldsager i graven kan man kun vide, på hvilket tidspunkt de senest kan være bygget. Da gravkisterne udviser stor formvariation, følger også, at før en kronologisk funderet typologi er etableret, lader det sig vanskeligt gøre at diskutere inspirationen til kisternes oprindelse, samt forholdet mellem lokaludvikling og fremmed påvirkning. 
Ved begrebet gravkiste forstås i dette arbejde ethvert gravkammer med åbning i den ene ende, og som stammer fra enkeltgravstiden eller senneolitikum. Den enkelte gravkiste kan være opdelt i gravrum, forrum og gang.

Gravrummet er den bageste del af gravkisten, adskilt fra den ydre del i åbningen af en tærskel eller en stenrække i stenkisterne. I de træbyggede ses ofte en grøft, hvori der oprindeligt må have ligget en trætærskel.

Gangen er den yderste del af gravkisten, hvis denne del består af et rektangulært rum, der er smallere end gravrummet.

Forrummet er den del af kisten, der ligger foran gravrummet og bag en evt. gang.

Mange af de nye fund af træbyggede gravkister kan i modsætning til de stenbyggede dateres ret snævert, da de førstnæunte selvsagt har en relativ kort brugstid, inden trækonstruktionen styrter sammen og umuliggør videre anvendelse. Det gravgods, der findes i de træbyggede gravkister, må derfor være nedlagt umiddelbart efter gravkammerets opførelse eller i løbet af så kort et åremål, at det arkæologisk set kan betragtes som samtidigt med bygningstiden, selvom der kan være foretaget flere successive gravlæggelser.

Dateringerne spænder over størstedelen af enkeltgravstiden og ind i senneolitikum. Da de træbyggede gravkister udviser en formmæssig variation, der svarer til de stenbyggede, åbnes muligheden for at foretage en typologisk analyse af materialet (fig. 1). Derved bliver det muligt at fastlægge de enkelte typer og varianters datering. Sluttelig er det muligt at belyse ændringer i gravkisternes udbredelse gennem enkeltgravstiden og senneolitikum. 


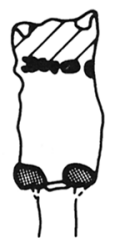

1. Sdr. Tranders

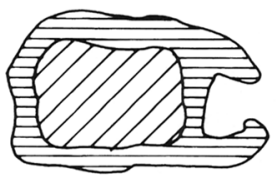

5. Kjeldgård Høj 2

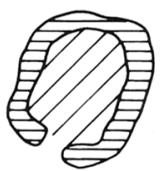

9. Vesthimmerlands Flyveplads Høj 2

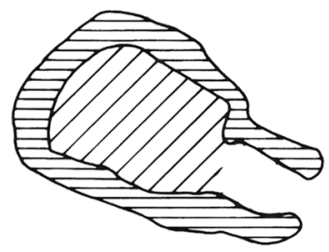

13. Hald

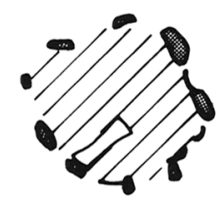

17. Glenstrup Grav17

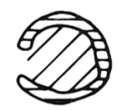

21. Sarup

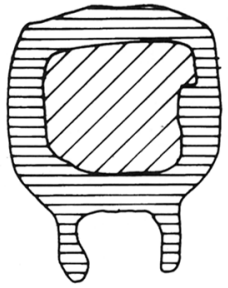

2. Volstrup

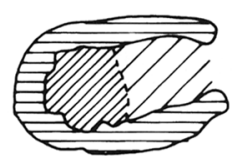

6. Kjeldgård Høj 4

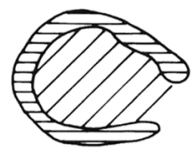

10. Vesthimmerlands Flyveplads Høj 3

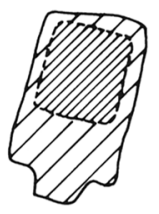

14. Kjeldagergård

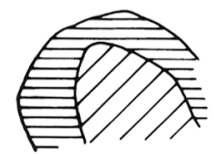

18. Koldkur Høj 11

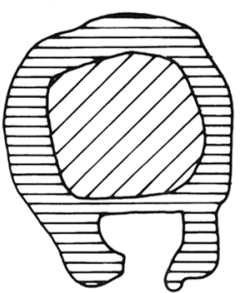

3. Kragehøj

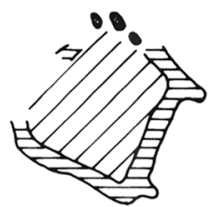

7. Kjeldgård Høj 5

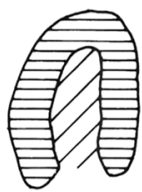

11. Kovhøj

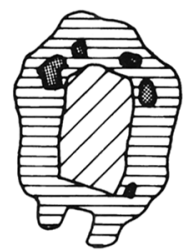

15. Toftelund

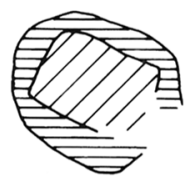

19. Koldkur Høj 14

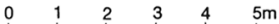

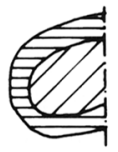

4. Kjeldgård Høj 1

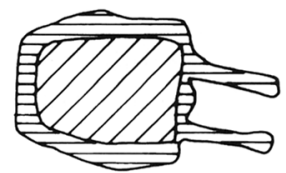

8. Vesthimmerlands Flyveplads Høj 1

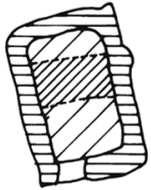

12. Rold

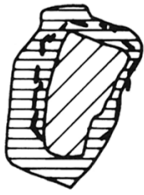

16. Drenghøj

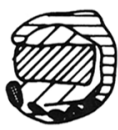

20. Damhalegård Grav Q

Stolpehul
Plankespor
Væggrøft
Gravrum
Område i grav-
rummet med
specielt fyld

Fig. 1. Oversigtstegninger af udvalgte træbyggede gravkister.

Overview of the selected wooden cists. 


\section{Udvalgte træbyggede gravkister}

I det følgende vil der blive fremlagt en række upublicerede træbyggede gravkister (fig. 1). En samlet oversigt over alle de træbyggede gravkister er fremlagt i katalog IA, IB, IIA, IIB og IIC. C-14 dateringerne angives i kalibrerede værdier \pm 1 standardafvigelse.

Vesthimmerlands flyveplads høj 3 Ulstrup sogn, Aars herred, Aalborg amt

Undersøgelsen er foretaget af forfatteren for Vesthimmerlands Museum, Aars i 1980 (Kat. IA.12).

Højen har en diameter på 20-22 m og var i centrum bevaret i op til en meters højde (fig. 2). De primære anlæg bestod af en fundtom grav og en simpel jordgrav med ravperler (8).

Som sekundært anlæg i højen fandtes en pæreformet, træbygget gravkiste (A1) med de indvendige mål på 3,2x2,4 m. Den var orienteret ØS $\varnothing-V N V$ med en $1,0 \mathrm{~m}$ bred indgang $\bmod \varnothing \mathrm{S} \varnothing$ (fig. 3). Nedgravningen kunne følges ned gennem højen, så snart græstørv og al-laget var fjernet. Den skilte sig klart ud fra den tørveopbyggede fyld i primærhøjen. De øverste spor af kammeret

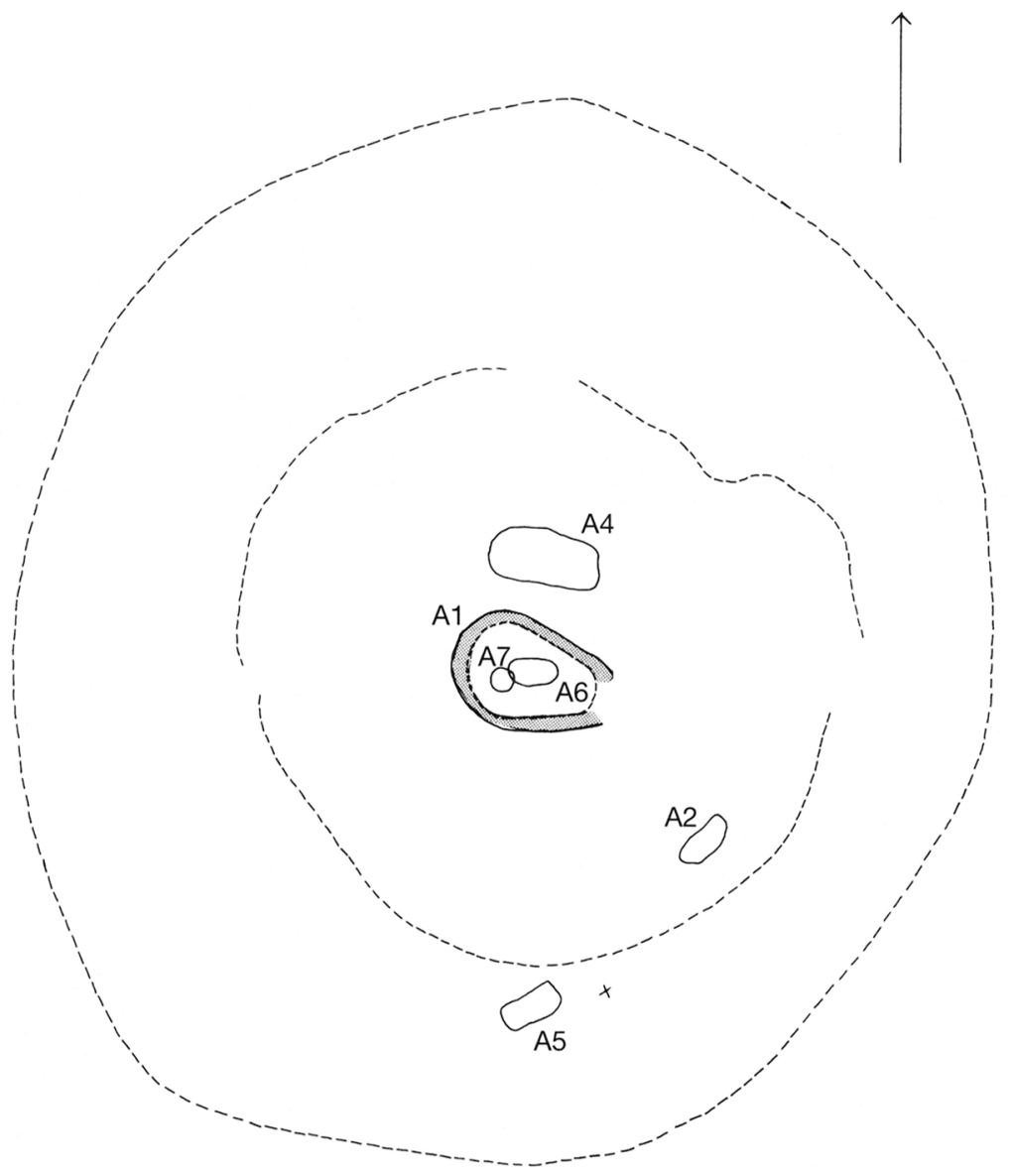

Fig. 2. Oversigtsplan over Vesthimmerlands Flyveplads høj 3 (IA.12). 1:200.

General plan of Vesthimmerlands landing field barrow 3 (IA.12). 1:200. 


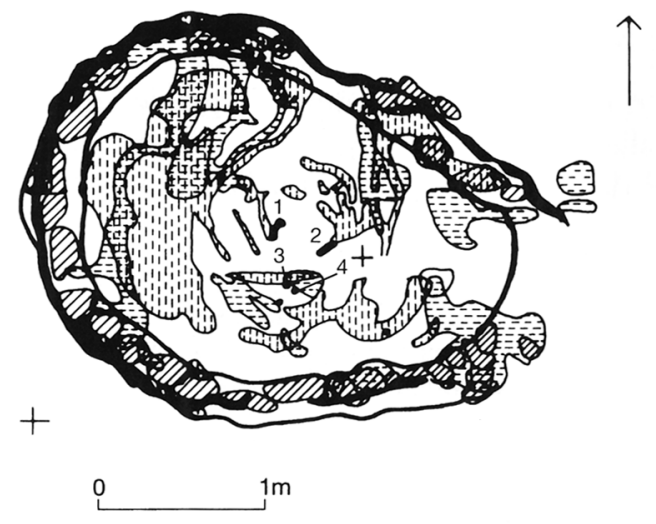

Fig. 3. Plan over træbygget gravkiste fra Vesthimmerlands Flyveplads høj 3. (IA.12). På planen er afsat grøft, støttesten, træspor, fund og prøver.

The wooden cist in Vesthimmerlands landing field barrow 3. The footing trench, support stones, traces of wood, finds and samples are shown.

var et næsten sammenhængende, 4-8 cm bredt fyldskifte af gulbrunt sand, der kantede et pæreformet område, samt nogle N-S-orienterede fyldskifter ligeledes af gulbrunt sand, der gik ind over kammeret. Dette kan tolkes som spor af formuldet træ fra væg og loft. Dybere nede og adskilt fra loftlaget af et lag fint sand, fandtes et sammenhængende gulbrunt lag, der må tolkes som gulvlaget. Det smalle fyldskifte i væggen kunne følges ned til en dybde af 0,40-0,50 m under gulvniveauet (fig. 4). Det var gravet ned i en grøft, hvori der langs væggens inderside var anbragt støttesten. Disse kunne følges hele vejen rundt undtagen ud for indgangen, hvor der heller ikke var spor af væg. Enkelte steder i det formuldede træ fandtes trækul. En prøve (fig. 3.7) fra nordvæggen indeholdt eg og lind, mens en prøve fra gulvlaget (fig. 3.8) indeholdt eg, lind, el og ubestemmelige barkstykker (9).

I den træbyggede gravkiste fandtes en stridsøkse af type F3, (fig. $3.1 \mathrm{og} 5.1$ ), en tyndbladet flint$ø$ kse, (fig. $3.2 \mathrm{og} 5.2$ ), en lille og en stor ravring, (fig. 3.3-4 og 5.3-4) (11).

Dateringen af graven angives dels af stridsøksen, der tilhører ældre bundgravstid og dels af 2 C14-dateringer. En prøve fra væggen dateres til 2840-2460 f.Kr. (kal.) og en prøve fra gulvlaget dateres til 2610-2460 f.Kr (kal.) (12).

\section{Drenghøi, Sejerslev sogn, S6 89, Morsø Norre herred, Thisted amt}

Udgravet i 1983 af Aase Vrang for Morslands Historiske Museum (Kat. IA.01).

Der var bevaret enkelte randsten og stenspor efter randsten, således at højens diameter kunne bestemmes til ca. $15 \mathrm{~m}$.

Gravkisten er træbygget og består af et gravrum (fig. 6). Gravkisten er af type A2a. Den er trapez- til pæreformet og måler $2,4 \times 1,2-1,8 \mathrm{~m}$, orienteringen er $\varnothing-\mathrm{V}$ med en svag drejning mod VNV-ØSØ med indgang i øst (fig. 6).

Centralt i højen fandtes et anlæg bestående af en 15-20 cm dyb og $40 \mathrm{~cm}$ bred grøft, der omsluttede et trapez- til pæreformet område, der er 2,5 m langt, 1,45 m bredt i vest og 0,90 m bredt i øst.

Grøften havde mod nord, syd og vest en hældning på indersiden på $45^{\circ}$, mens den mod øst var næsten lodret $\left(\mathrm{ca} .80^{\circ}\right.$ ). Omkring anlægget lå en U-formet stenbræmme. I den vestlige del af sydsiden lå nogle af stenene nede $\mathrm{i}$ grøften. De andre steder lå de uden for. I grøftens bund fandtes spor af 15 formuldede planker. Plankerne er 0,15-0,50 m brede og 0,03-0,08 m tykke. Plankesporene gik 0,1-0,38 m ned under grøftens bund og 0,27-0,59 under gulvniveauet. Nogle var lodretstillede, mens andre skrånede ind mod kammeret.

Direkte på undergrunden inde i selve gravrummet lå et tyndt trækulslag. Det stammer næppe fra en afbrænding af kammeret, men snarere fra en svitsning af gulvplankerne. Flere steder kunne det ses, at træet/plankerne har ligget i nord-sydlig retning, på tværs af kammeret. Laget kan flere steder følges ud over en del af grøften, helt ud til aftrykkene af vægstolperne.

Over gulvplankelaget lå gravlaget, et ca. $6 \mathrm{~cm}$ tykt gråt sandlag med en del trækul. Dette lag 


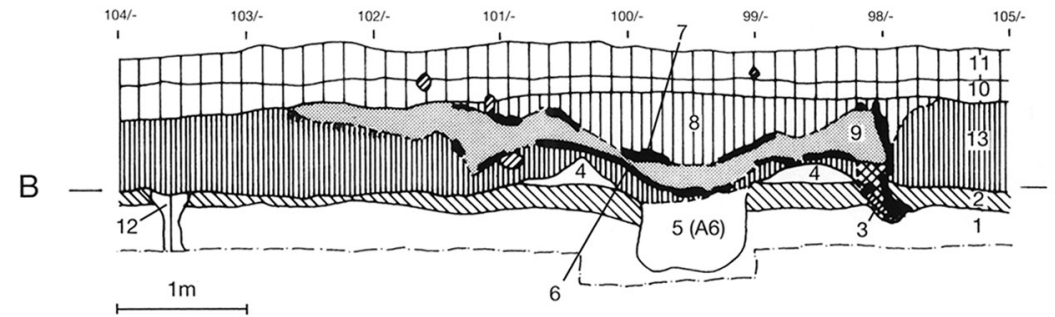

Fig. 4. Vesthimmerlands Flyveplads høj 3 (IA.12). Tegning af Ø-V-profil gennem højen (A) og detailtegning af partiet med gravkisten fra samme profil (B).

Nederst ses undergrunden (lag 1), derefter følger det oprindelige muldlag fra før højens anlæggelse (lag 2). Graven A6 (lag 5) ses at være nedgravet gennem lag 1 og lag 2. Det opgravede materiale ses som lag 4 på begge sider af nedgravningen. Over grav A6 er der opbygget en høj af græstørv i form af lag 13. I denne høj foretages en nedgravning, hvor den træbyggede gravkiste anlægges. Her skal særlig fremhæves lag 6, der er det formuldede gulvlag og lag 7, der er det formuldede loft. Disse 2 lag er adskilt af et 5-20 cm tykt lag fint sand uden tørvespor (lag 9) - antagelig sand, der er blæst ind i kammeret, mens det har stået åbent. Ved 101,25/findes kammerets indgang og øst herfor skråner nedgravningen op mod højoverfladen. Mod vest omkring 98,00/- ses den lodrette nedgravning og tydelige rester af kammerets vestgavl, der her kan følges $0,40 \mathrm{~m}$ under gulvlaget (lag 3). Det er bemærkelsesværdigt, at lagene hen over grav A6 viser, at kammerets loft og gulv er sunket $0,2 \mathrm{~m}$. Det kan kun tolkes som et tegn på, at fylden i grav A6 har sat sig, eventuelt i forbindelse med at en trækiste i graven er faldet sammen. Dette er tydeligvis forst sket efter, at den træbyggede gravkiste er gået af brug, blevet delvis fyldt med sand og styrtet sammen. Dette forhold bekræfter formodningen om, at gravkisterne må have haft en relativ kort brugstid. Lag 8: Den nedskredne højfyld/sekundær opfyldning inden højudvidelsen. Lag 10: Højfyld fra sekundær udvidelse. Lag 11: Mulddannelse. Lag 12: Forstyrrelse i oldtiden.

Vesthimmerlands landing field barrow 3 (IA.12). (A) E-W section through mound, (B) detail from same section showing burial cist. At base natural subsoil (1). Above this original soil from before mound was built (2). Grave A6 (5) is dug through layers 1 and 2. The spoil from its excavation is seen on both sides (layer 4). Over grave A6 was built a mound of grass sods (5) and (13). The wooden cist was inserted into this mound. Attention is called to (6), which is the remains of its floor, and (7), the remains of its roof. These two layers are separated by a $5-20 \mathrm{~cm}$ thick layer of sand without any trace of sods (9) in it. This is probably sand that was blown into the cist when it stood open. At co-ordinate 101.25/- is seen the entrance of the burial chamber, and east of it the floor of the excavation slopes up towards the mound surface. At about $-8.00 /-$ is seen the vertical side of the excavation and clear traces of the western end of the chamber, which can be followed to $0.40 \mathrm{~m}$ below floor level. It should be observed that the deposits above grave A6 show that the roof and floor of the chamber have sunk $0.2 \mathrm{~m}$. This can only mean that the fill in Grave A6 has subsided, perhaps because a wooden cist in it collapsed. Clearly this occurred only after the wooden cist had fallen out of use, become partly filled with sand, and collapsed. This gives support to the opinion that the wooden cists were only in use for a short time.

kunne følges over hele gravrummet og udgjorde flere steder også fylden i grøften. Over gravlaget fandtes et tyndt lag af mørkebrunt til sortbrunt sand, der er de formuldede rester af sammen-styrtede vagge og loft.

Ved indgangen i gravens østende var laget af formuldet og svitset træ tykkere. Op til $0,70 \mathrm{~m}$ inden for indgangen og $0,30 \mathrm{~m}$ uden for kammeret, og i ca. 1 meters bredde lå træet $\mathrm{i}$ retningen NV-SØ. Umiddelbart øst herfor, i forlængelse af dette lag, lå i en afstand af op til 0,60 m fra gravrummet træ med retningen SV-NØ. Dette kraftige trælag, der er bestemt til egetræ, dækker et område på 1,25x1,00 m og repræsenterer antagelig en dør.

Bagest i gravkammeret fandtes skeletspor og tandemalje fra 2 personer samt et sideskår fra et lerkar (fig. 6.1, 2). I den nordvestlige del af kammeret fandtes 5 ravperler (fig. 6.3, 6). Omtrent midt for sydvæggen fandtes en stump af en rørknogle (fig. 6.7). Mellem rørknoglen og de andre 

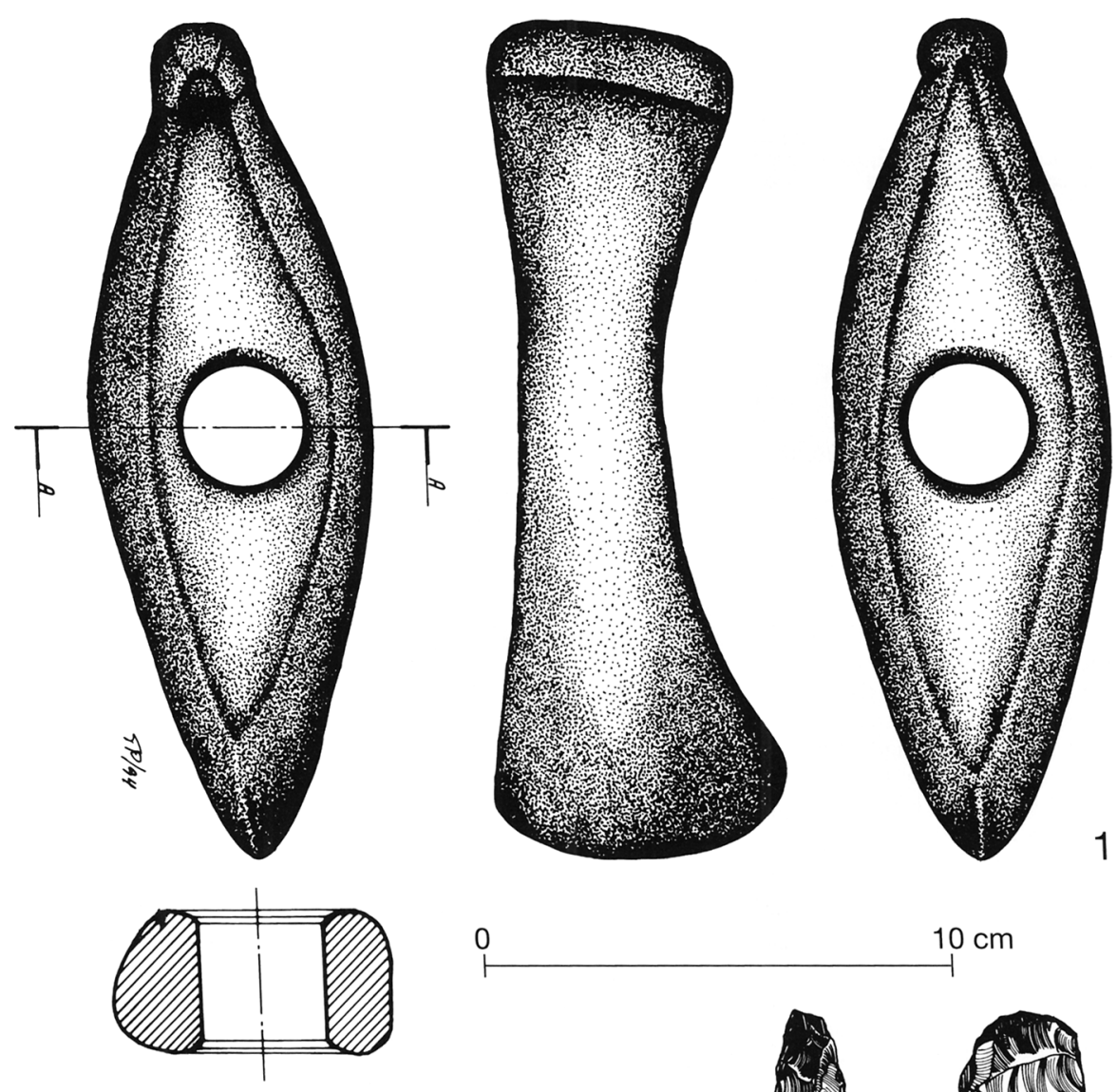

$10 \mathrm{~cm}$

Snit: $A-A$

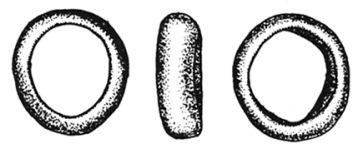

2
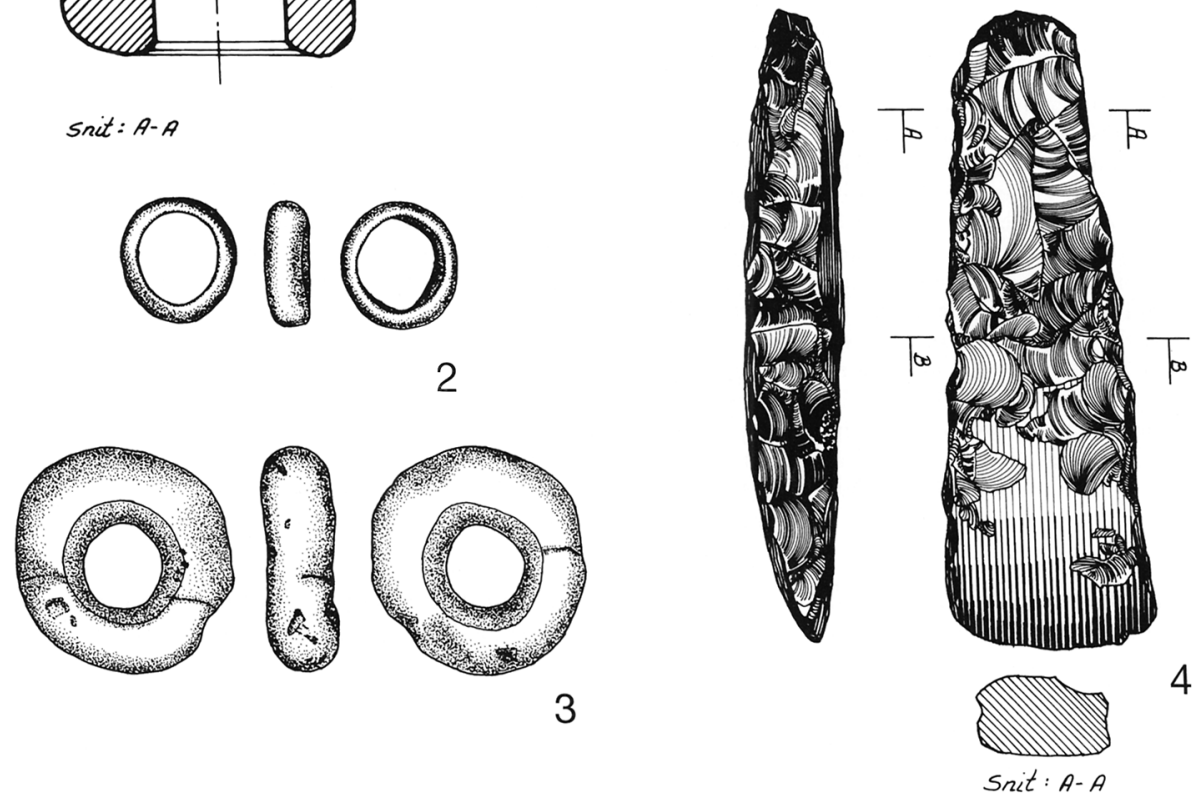

Fig. 5. Fundene fra gravkisten fra Vesthimmerlands Flyveplads Høj 3.

1. Stridsøkse. 2. Tyndbladet flintøkse. 3. Ravring. 4. Ravring. 5. Ravperle. 6. Ravperle. 1:2.

The finds from the wooden cist at Vesthimmerlands landing field, barrow 3 .

1. battleaxe. 2. Thin-bladed axe of flint. 3-4. Amber rings. 5-6. Amber beads. 1:2.

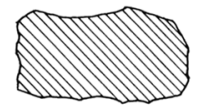

Snit: $B-B$ 
Fig. 6: Grundplan over Drenghøj (IA.01).

Plan of Drenghøj (IA.01).

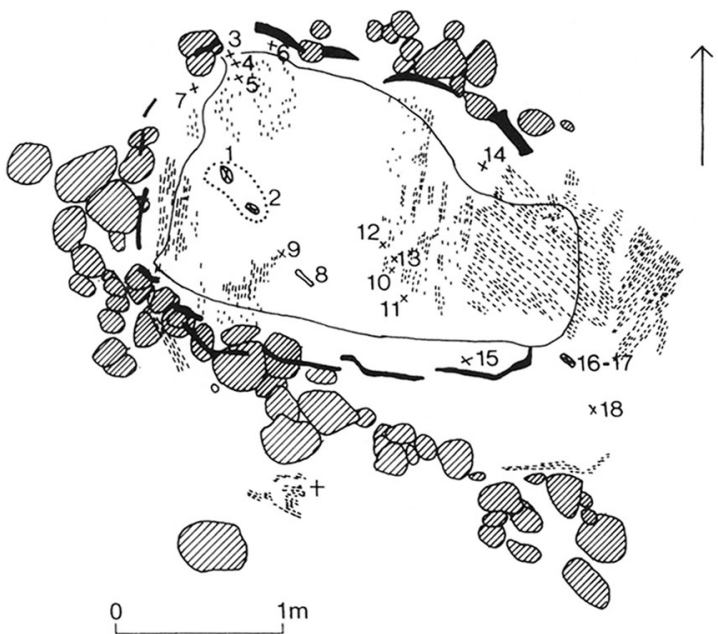

skeletspor fandtes et ornamenteret sideskår (fig. 6.8). Lidt øst herfor lå endnu en samling ravperler (fig. 6.9, 12). Blandt dem lå en ravring (fig. 6.11). Ravringen har en ydre diameter på $2,1 \mathrm{~cm} \mathrm{og}$ en indre diameter på $0,7 \mathrm{~cm}$. Tværsnittet er lidt uregelmæssigt afrundet til rektangulært. Ude $\mathrm{i}$ kammerets side over grøften, lå endnu 2 ravperler (fig. 6.14-15). Disse fund, der stammer fra begravelse af mindst 2 individer, er placeret direkte på gulvplankerne.

Efter aflejringen af det grå sandede gravlag er der yderst $\mathrm{i}$ kammeret foretaget endnu en begravelse. Her fandtes, delvis udskredet i grøften, men dækket af formuldede vægplanker, et velbevaret tandsæt (fig. 6.15), et ornamenteret randskår og 2 afslag (fig. 6.16-17). Lidt længere ude i grøften fandtes endnu en ravperle (fig. 6.17). Tandsættet stammer i følge professor Philipsen, Arhus Tandlægehøjskole fra et individ på ca. 25 år.

Graven kan på grundlag af ravringen dateres til bundgravstid, mens keramikken ikke kan placeres nærmere inden for enkeltgravskulturen. Der er foretaget to $\mathrm{C}-14$ dateringer af egetræ fra "døren« med resultater på henholdsvis 2870-2500 f.Kr. (kal.) og 2570-2460 f.Kr. (kal.) (12).

I pløjelaget over graven fandtes en stridsøkse af type $\mathrm{G} / \mathrm{H}$. Denne økse stammer sandsynligvis fra graven og vil i så fald støtte dateringen til ældre bundgravstid.

Vesthimmerlands flyveplads 1, Hvorvarp, (120812) Ulstrup sogn, Aars herred, Aalborg amt

Undersøgelsen er foretaget af forfatteren for Vesthimmerlands Museum i 1980. (Kat. IA.10).

Højen har en diameter på $19 \mathrm{~m}$. Den var i centrum bevaret i 1,00 meters højde. (fig. 7).

Gravkisten, der var højens primære og eneste grav består af gravrum og gang. Gravkisten er af type A3b (fig. 8). Gravrummet er let trapezformet, idet bredden er 1,80-2,00 m, bredest ved bagvæggen. Længden er 2,9 m. Fra kammeret udgår den 1,80 m lange og 0,8 m brede gang. Gravkisten er $\varnothing-\mathrm{V}$-orienteret med indgang $\mathrm{i}$ øst.

Anlægget har en væggrøft, der er 0,30-0,50 m bred (enkelte steder helt ned til 0,20 m). Dybden er 0,35-0,67 $\mathrm{m}$ under gulvlaget. Flere steder i bunden af grøften er der svage fordybninger, fylden er løsere og lidt brunlig, hvilket antyder tilstedeværelsen af stolper, men ingen af dem er sikre. I den østligste afslutning på gangens grøfter findes i hver af grøfterne 2 hovedstore sten liggende oven på hinanden.

I forbindelse med anlægget fandtes en del spor af formuldet træ $\mathrm{i}$ form af gulbrunt sand. De højstliggende spor fandtes i niv. 116-120 (vandret, stiplet skravering). De findes særligt som større flager omkring gangen, som smalle striber langs kammerets kant og som $\varnothing-V$-orienterede bælter ind over kammeret. I et dybere niveau (niv. 134-145) (lodret, stiplet skravering) fortsætter de smalle striber ned langs kammerets kant, men nu findes der også større flager og bælter, der løber N-S ind over kammeret. Desuden findes fyldskifterne i gangen. Disse iagttagelser må tolkes såle- 


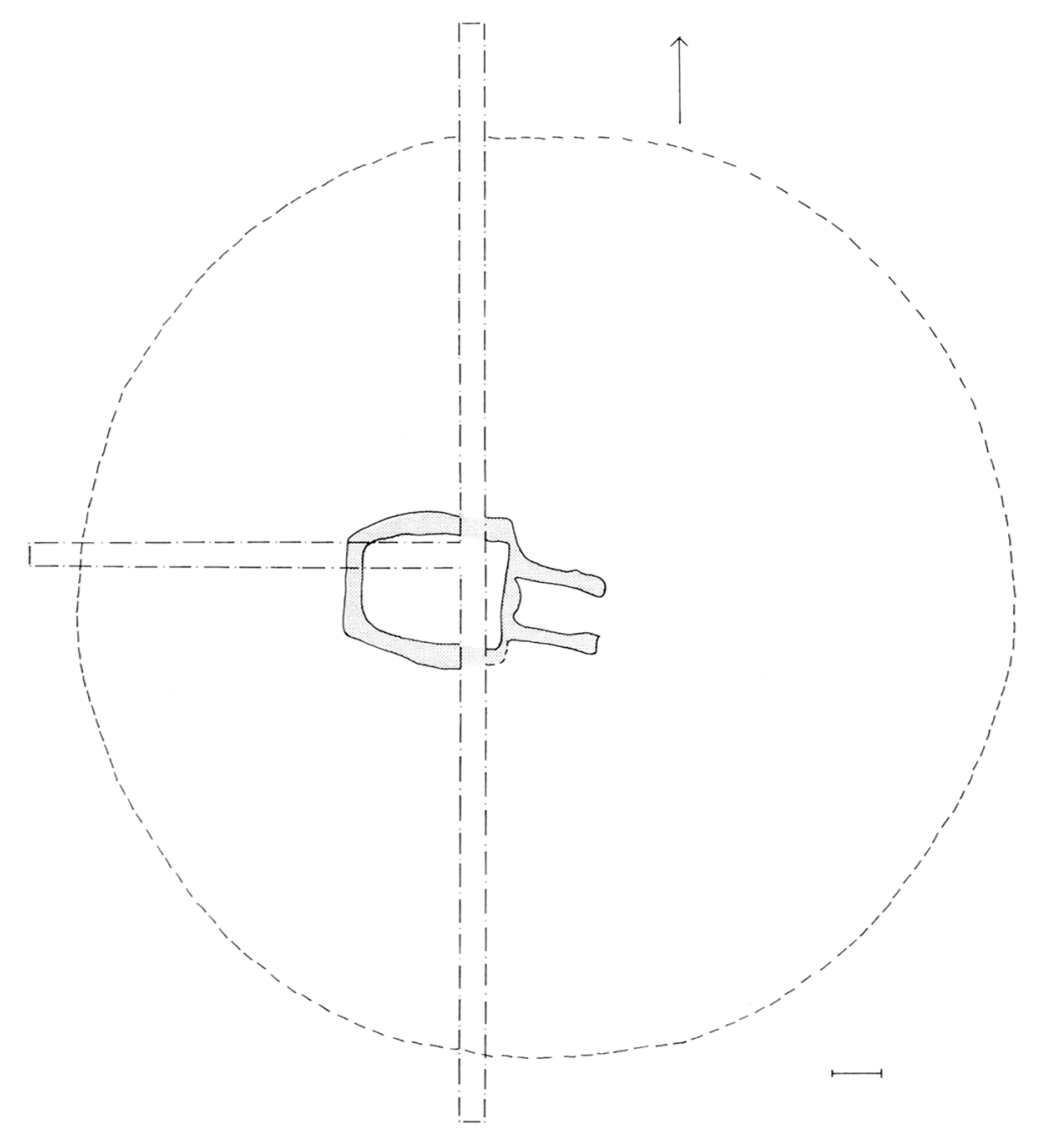

Fig. 7. Oversigtsplan over Vesthimmerlands Flyveplads, Høj 1.

General plan of Vesthimmerlands landing field, barrow 1.

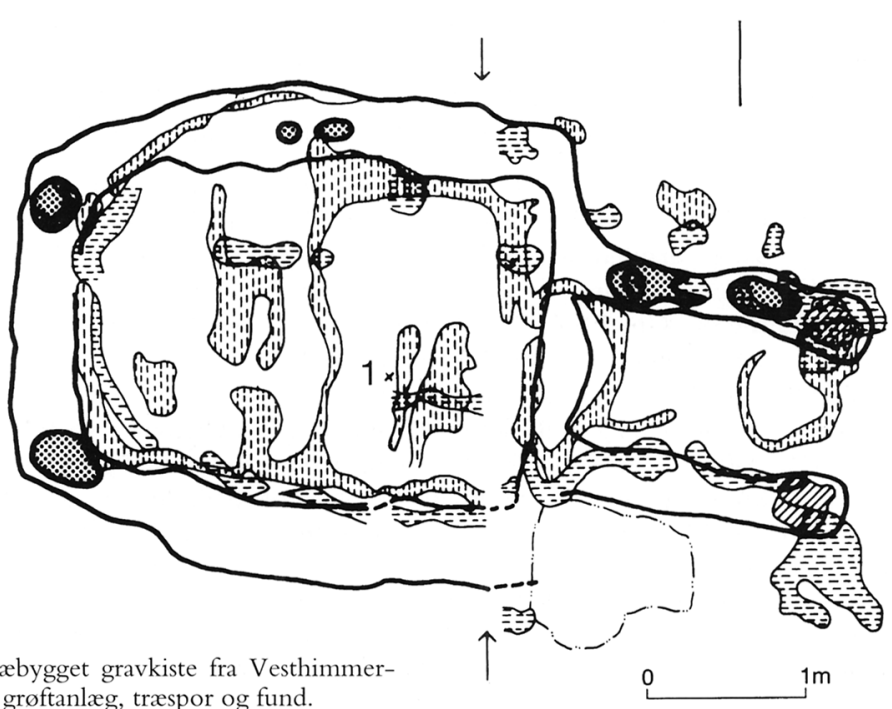

Fig. 8. Plantegning over træbygget gravkiste fra Vesthimmerlands Flyveplads, høj 1 med grøftanlæg, træspor og fund.

Plan of the wooden cist in Vesthimmerlands landing field, barrow 1 , showing footing trench, traces of wood, and finds. 

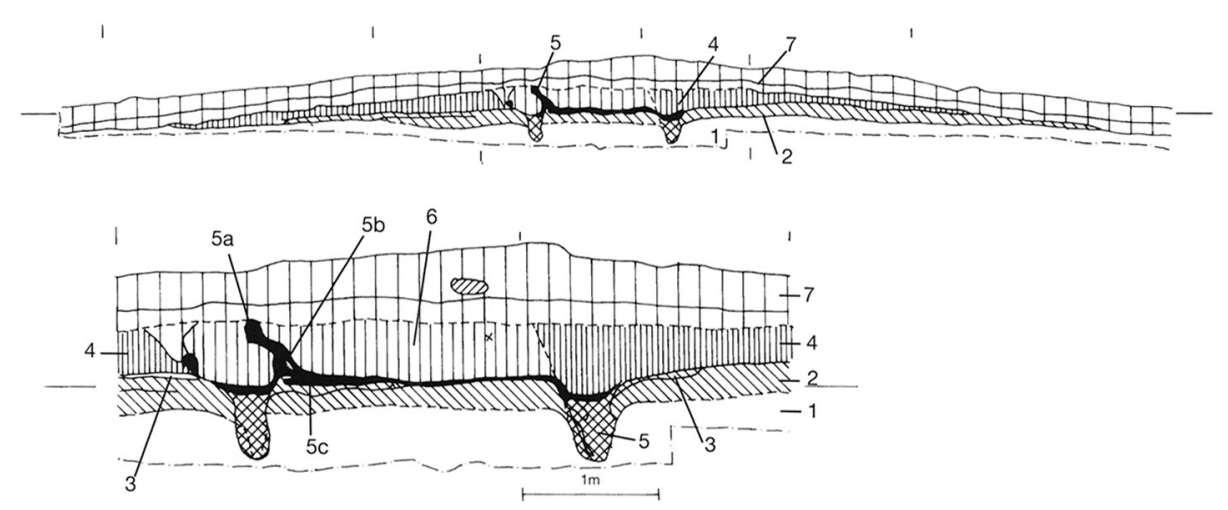

Fig. 9. Profiltegning af N-S-snit gennem gravkisten fra Vesthimmerlands Flyveplads Høj 1. Set fra Øst. 1. Undergrundssand. 2. Oprindeligt muldlag. 3. Opgravet undergrundssand. 4. Højfyld. 5. Væggrøft. 6. Nedstyrtet højfyld over graven. 7. Nyere muldlag i to faser.

$\mathrm{N}-\mathrm{S}$ section through the cist in Vesthimmerlands landing field, barrow 1, seen from E.

des, at de højtliggende rester af formuldet træ repræsenterer dele af trævægge, en særlig beklædning af siderne omkring gangen og rester af et ikke helt nedstyrtet loft. De dybere liggende lag må repræsentere gulvet og nogle steder også dele af det nedstyrtede loft. Det er bemærkelsesværdigt, at sporene af formuldet træ fra væggene ikke kan følges ned i grøften.

Som et væsentligt supplement til disse iagttagelser står det N-S-orienterede profil gennem den forreste del af kammeret (fig. 9). I profilet er det muligt at udskille træsporene i et gulvlag (lag $5 \mathrm{c}$ ), en væg (lag $5 \mathrm{a}$ ) og resterne af det nedstyrtede loft (lag 5b). Væggen kan på dette sted følges op til $0,70 \mathrm{~m}$ over gulvet.

Af profilet fremgår det også, at det formuldede træ kan følges udover grøften. Sammenholdes det med, at der måske har været stolper i grøften, og at vægkonstruktionen tilsyneladende ikke går ned i grøften, kan man forestille sig en konstruktion med lodrette stolper i grøften, som har været beklædt med planker (vandrette?) fra kammerets gulv og op til loftet.

Det opgravede undergrundsmateriale, anbragt på det oprindelige muldlag omkring grøfterne (fig. 9, lag 3), dokumenterer, at graven er primær. Samtidig viser profilet med vægresterne og den tørveopbyggede høj uden for kammeret, at gravkisten har stået inde i højen i funktionstiden.

I kammeret fandtes en lille ravring, liggende på kammerets gulv i det gulbrune løse sand (fig. 8.1) (13). Ringen kan dateres til ældre bundgravstid (Glob 1944, 152). Der var ikke trækul nok til en C-14-datering (14).

Kragehøj, Øster Hornum sogn, Sb 13, Hornum herred, Aalborg amt Undersøgelsen er foretaget af mag. art. Jannie L. Nielsen, Aalborg Historiske Museum i 1977. (Kat. IA.08).

Højen har en diameter på 20-24 m og var i centrum bevaret i op til 2 meters højde.

Som primært anlæg i højen fandtes en træbygget gravkiste bestånde af gravrum og forrum. Gravkisten er af type B2a. (fig. 10). Gravrummet er rektangulært med afrundede hjørner, 2,60x2,90 m. Forrummet er 1,40 m langt og 0,80-1,80 m bredt. Graven er N-S-orienteret med indgang mod syd. Anlægget har en væggrøft, der er 0,3-1,2 m bred og en dybde på 0,75-0,95 m under gravens gulvlag. Grøften er smallest mellem gravrum og forrum. Langs indersiden af grøfterne findes en $6 \mathrm{~cm}$ bred stribe af gulbrunt, løst, humøst sand. Denne fyld kan følges næsten til grøftens bund. På profiltegningen (fig. 11) ses det desuden, at striben kan følges op i højfylden; her må den repræsentere resterne af den væltede væg.

I gravrummet fandtes rester af mindst 8 begravelser i form af tandemalje liggende oven på et tyndt sandblandet trækulslag. Af tandemaljens placering fremgår det, at 5 af de døde har ligget med hovedet mod vest, mens 3 har ligget med hovedet mod øst. På grund af mangel på knoglespor og de mange begravelser på samme gulvflade lader de fundne oldsager sig kun $\mathrm{i}$ et vist omfang knytte til hinanden og til fundene af tandemalje. 
Til tandemalje (fig. 10.1) knytter sig ravperlerne (fig. 10.2), der er 14 små ravperler og fragmenter af 2-3 ravperler, (fig. 10.3), der er en dråbeformet ravperle, (fig. 10.4), der er 3 flækkepile. Heraf er en 5,7 cm lang lancetformet pil, en 5,0 cm lang skafttungepil, der udelukkende er retoucheret på begge sider af skafttungen og en $4,8 \mathrm{~cm}$ lang skafttungepil, retoucheret langs alle kanter.

Herudover kan der ikke sammenknyttes fund af tandemalje (fig. 10.5, 11) og oldsager. Men generelt er der en tendens til, at koncentrationerne med mange ravperler (perlekæder) findes $\mathrm{i}$ gravens østlige og midterste del (fig. 10.2, fig. 10.12, fig. 10.13), mens spredningen af enkeltliggende eller 2-3 perler sammen findes i gravens vestlige del. En del af ravperlerne lå ved gennemgangen af fundet i de præparater, som de er optaget i, hvorfor der ikke kan foretages en samlet fremlæggelse af ravperlerne.

I gravens vestlige del fandtes 2 flintøkser. Den ene (fig. 10.14) er en tyknakket, hulægget flintøkse. Den anden er en tyknakket retøkse (fig. 10.15).

Omtrent midt i gravrummet fandtes en stridsøkse af sten, men overtrukket med ler (fig. 10.16) af type H1d.

I graven fandtes 3 lerkar: Karret (fig. 10.17) (15) er enestående inden for den danske enkeltgravskeramik og lader sig derfor også vanskeligt indplacere i Globs keramikgrupper. Ligheden er størst med D-gruppen. Fig. 10.18 og fig. 12.1 (16) er et svajet bæger af type B2. Fig. 10.19 og fig. 12.2 (17) er et lavt, svajet lerkar af type C1.

Gravkisten kan ud fra stridsøksen dateres til ældre bundgravstid. Dette bekræftes også af lerkarrene (fig. 12.1-2). Derimod kan ingen af de øvrige oldsager dateres nærmere inden for enkeltgravskulturen.

Gravgodsets placeringer viser, at der blev gravlagt både mænd og kvinder i graven, og at kvinderne lå med hovedet mod øst og mændene med hovedet mod vest.

En C-14 datering af trækul (eg) fra gulvlaget i den nord-østlige del af kammeret gav resultatet 2480-2210 f.Kr. (kal.) (19).

Volstrup, Ø. Hornum sogn, Sb 12, Hornum herred, Aalborg amt

Undersøgelsen er foretaget af mag. art. Jannie L. Nielsen, Aalborg Historiske Museum i 1977. (Kat. IA.07).

Højen var ca. $17 \mathrm{~m}$ i diameter og i centrum bevaret i op til 0,80 m. Gravkisten er træbygget og består af gravrum og forrum. Gravkisten er af type B2 (fig. 13). Gravrummet er rektangulært og 2,8 $\mathrm{m}$ langt og 2,6 $\mathrm{m}$ bredt. Forrummet er 1,3 m langt og 1,4-1,6 m bredt. Graven er N-S-orienteret med indgang i syd. Gravrummet er omgivet af en 0,60-0,90 m bred grøft med en dybde på 0,75-0,95 m under gravens gulv. Mellem gravrum og forrum er den dog kun 0,60 m dyb. Grøfterne på forrummets yderside er kun 0,40-0,60 m brede. På indersiden af grøfterne, omkring gravrummet er der i øst- og nordsiden bevaret flere 5-10 cm brede og 20-30 cm lange fyldskifter af løst, gulbrunt, humøst sand. Nogle steder er der på indersiden af disse fyldskifter en smal stribe af trækul fra egetræ. Disse spor, der må opfattes som svitsede vægplanker, står lodret eller skråner ganske let ind mod kammeret.

I gravrummet fandtes spor af mindst 4 gravlagte personer. Lig III (fig. 13.III) kunne erkendes i form af tandemalje (fig. 13.6) samt rester af skinne- og lårben (fig. 13.7). Skeletresterne viser, at den døde har ligget udstrakt på ryggen med hovedet mod vest. Til dette lig kan knyttes en $6,7 \mathrm{~cm}$ lang flækkepil af type D (fig. 13.8).

Lig II kunne kun erkendes $\mathrm{i}$ form af tandemalje (fig. 13.3). Hertil kan knyttes en tyknakket hulægget flintøkse (fig. 13.5) samt en $6,5 \mathrm{~cm}$ lang og $1,5 \mathrm{~cm}$ bred flækkepil (fig. 13.4). Den er spidsoval og har firsidet tværsnit. Den må nærmest betegnes som en atypisk D-pil. En lignende pil kendes fra en grav ved Vojens (Albrectsen \& Street-Jensen 1964, 21 og fig. 14A2). Den døde har antagelig ligget orienteret $\varnothing-\mathrm{V}$ med hovedet mod vest.

Lig IV lå i kammerets sydlige del. Her var bevaret rester af skinne- og lårben (fig. 13.13) samt tandemalje (fig. 13.9). Også her har den døde ligget på ryggen med hovedet i vest. Til dette lig kan der ikke knyttes gravgaver.

Lig I lå i kammerets nordlige del. Her fandtes tandemalje (fig. 13.1). Til dette lig kan knyttes en tyknakket hulægget flintøkse (fig. 13.2). I forbindelse med øksen fandtes rester af formuldet træ, der muligvis stammer fra en trækiste, hvori den døde har været anbragt. Også i dette tilfælde ser den døde ud til at have ligget orienteret $\varnothing-\mathrm{V}$ med hovedet mod vest. 


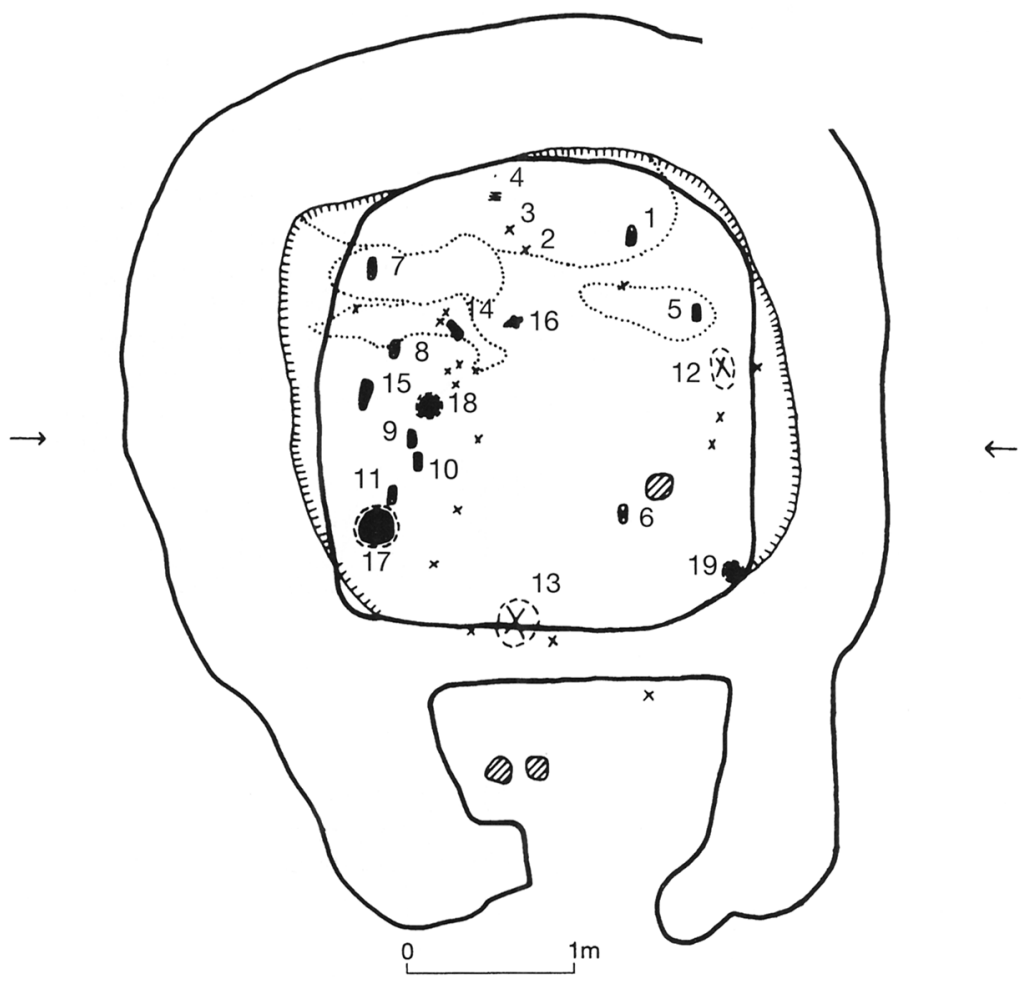

Fig. 10. Plan over den træbyggede gravkiste fra Kragehøj. 1.Tandemalje. 2. Ravperler. 3. Dråbeformet ravperle. 4. Tre flrkkepile. 5. Tandemalje. 6. Tandemalje. 7. Tandemalje. 8. Tandemalje. 9. Tandemalje. 10. Tandemalje. 11. Tandemalje. 12. Ravperler. 13. Ravperler. 14. Tyknakket hulægget flintøkse. 15. Tyknakket retøkse af flint. 16. Stridsøkse, type H1d. 17. Lerkar. 18. Lerkar. 19. Lerkar.

Plan of the wooden cist at Kragehøj.

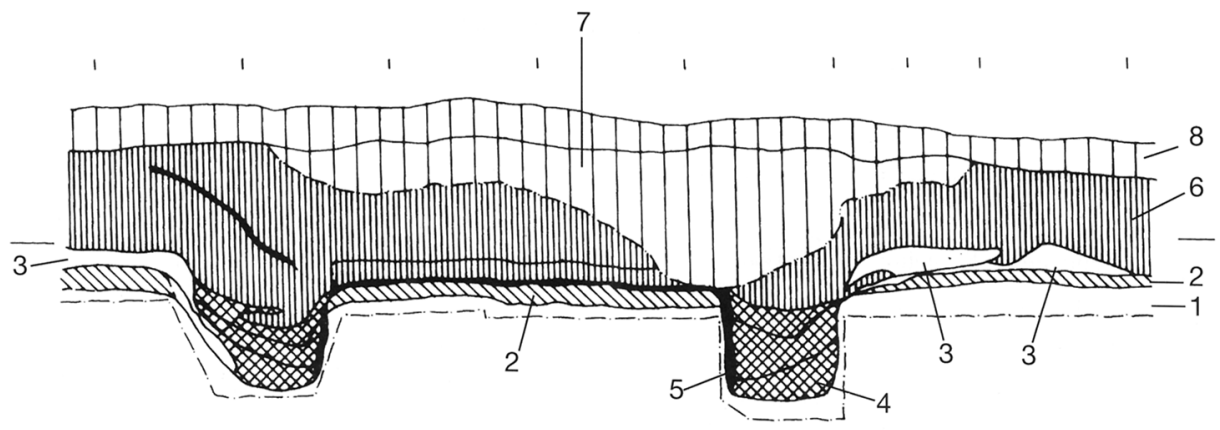

Fig. 11. Ø-V-profil gennem den træbyggede gravkiste fra Kragehøj. Nederst ses undergrunden. Den er gennemgravet af grøfterne. Derefter følger det oprindelige muldlag. Det opgravede undergrundsmateriale ligger på muldlaget. Højfylden er forstyrret i moderne tid. 1. Undergrundsmateriale. 2. Oprindeligt muldlag. 3. Opgravet undergrundsmateriale. 4. Væggrøft. 5. Spor af formuldet/forkullet træ. 6. Højfyld. 7. Moderne forstyrrelse. 8. Nyere muldlag.

E-W section through the wooden cist from Kragehøj. At base natural subsoil. This is penetrated by the footing trench. Next comes the old soil, on which some subsoil has been redeposited. The mound fill is disturbed. 

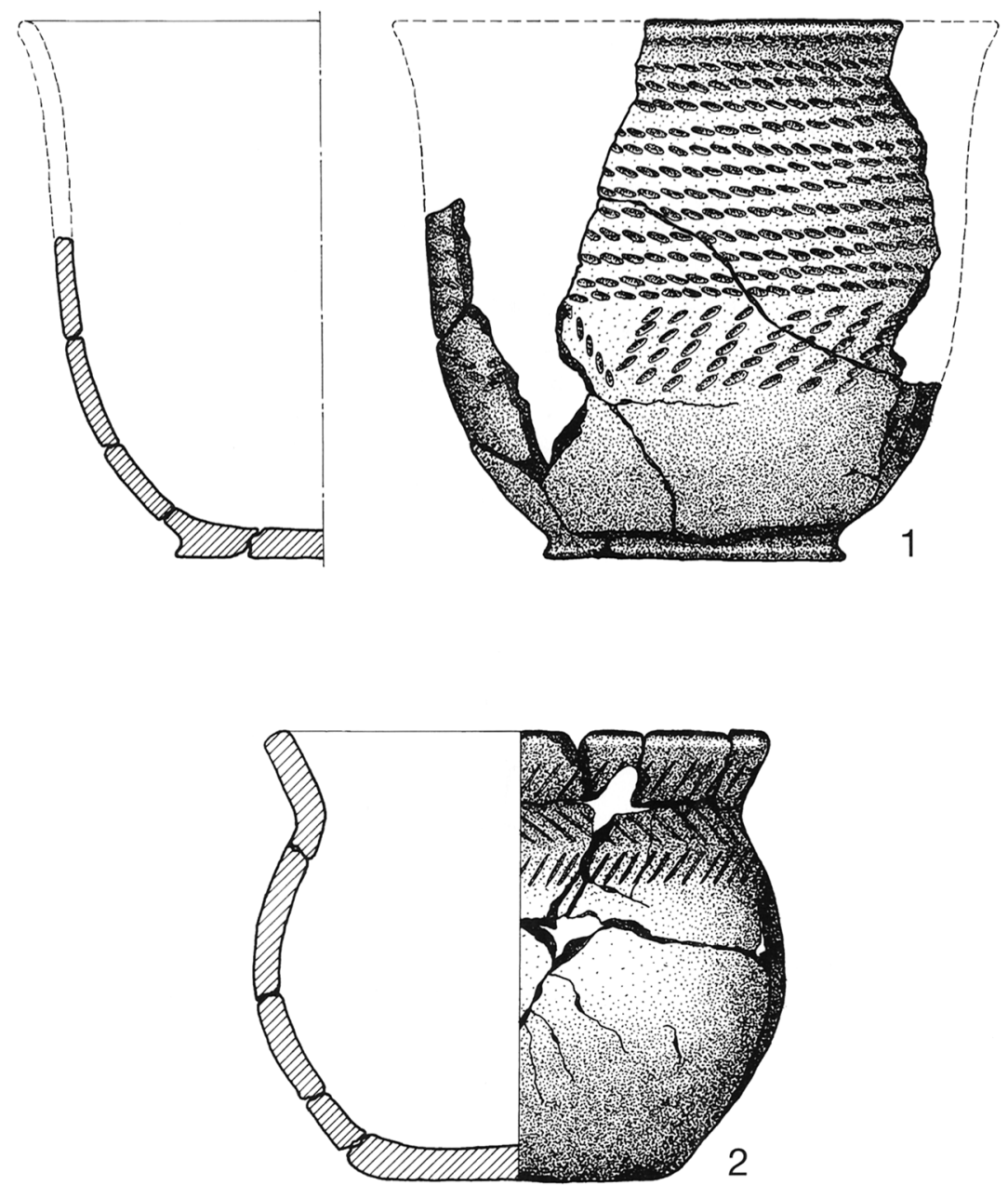

0 5 10

Fig. 12. Fundene fra Kragehøj: 1-2. Lerkar.

Finds from Kragehøj: 1-2. Pots.

Lig I og II var dækket af et tyndt lag mørkebrunt til sort humus, mens III og IV var dækket af gulligt sand. Lig I og II er begravet før III og IV.

3 oldsager kan kun med nogen usikkerhed knyttes til de enkelte ligspor. Det drejer sig om en stridsøkse (fig. 13.10), der med nogen forsigtighed kan bestemmes som type H1e. Skønt den i enkelte detaljer minder lidt om typerne $\mathrm{K}$ og L, mangler den dog disse typers tilbagetrukne skafthul. Den lå nedskredet i væggrøften. Skønt den sandsynligvis skal knyttes til Lig I, kan det dog ikke udelukkes, at den repræsenterer en selvstændig begravelse. I den vestlige grøft fandtes en tyknakket hulægget flintøkse (fig. 13.11) samt en 5,3 cm lang flækkepil af type D (fig. 13.12).

Graven dateres til ældre bundgravstid af stridsøksen. En C-14 datering af trækul fra en vægplanke gav resultatet 2550-2280 f.Kr. (kal.) (19). 


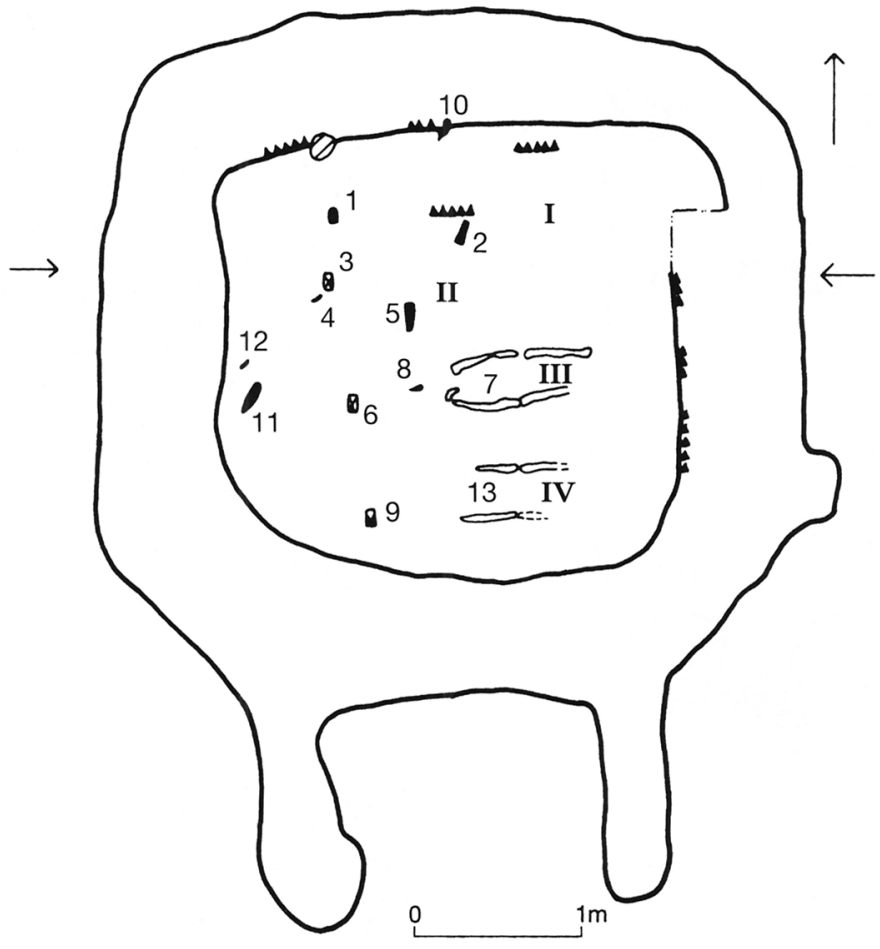

Fig. 13. Plan over træbygget gravkiste fra Volstrup IA.07. 1. Tandemalje; 2. Tyknakket, hulægget flintøkse. 3. Tandemalje. 4. Flækkepil. 5. Tyknakket, hulægget flintøkse. 6. Tandemalje. 7. Rester af skinne- og lårben, lig III. 8. Flækkepil. 9. Tandemalje. 10. Stridsøkse. 11. Tyknakket, hulægget flintøkse. 12. Flækkepil. 13. Rester af skinne- og lårben, lig IV.

Plan of the wooden cist at Volstrup (IA.07).

Keldgård høj 2, Aars sogn, Sb 145, Aars herred, Aalborg amt

Undersøgelsen er foretaget af forfatteren for Vesthimmerlands Museum, Aars i 1978 (Kat. IA.13).

Den primære høj på stedet var 10 meter i diameter og dækkede over en stenkiste fra tragtbægerkulturen. I kanten af denne høj var den træbyggede gravkiste anlagt og højen udvidet, så den fik en diameter på 14 meter. Højen var stærkt nedpløjet.

Den træbyggede gravkiste består af gravrum og forrum. (fig. 1.5). Gravkisten er af type B2. Graven er orienteret $\varnothing-\mathrm{V}$ med indgang i øst. Gravrummet er rektangulært og måler indvendig 2,95 x 2,00-2,20 m. Forrummet er 1,00 m langt og 1,00-1,35 m bredt. Gravrum og forrum er omgivet af 0,40-0,60 m brede og 0,60-0,70 m dybe grøfter. Langs indersiden af grøfterne kan der iagttages en smal stribe af gulbrunt humøst sand. Et par steder fandtes der trækul i fyldstriben. Flere steder kunne striben af gulbrunt humøst sand følges lodret ned langs grøftens side, næsten til grøftens bund. Disse striber er antageligt spor af en trævæg. I bunden af grøfterne fandtes nogle ovale fyldskifter, der målte fra $0,20 \times 0,15 \mathrm{~m}$ til $0,65 \times 0,38 \mathrm{~m}$. De går mellem $0,2 \mathrm{og} 0,23 \mathrm{~m}$ ned under grøftens bund. På grund af størrelsen er de dog næppe stolpehuller. I den nordlige grøft i forrummet fandtes en større flad sten, der muligvis har støttet trævæggen.

Der fandtes intet gravgods i graven, men i pløjelaget over den lå en stridsøkse af type H3b fra ældre bundgravstid, som kan være pløjet op fra graven.

Sender Tranders, Sender Tranders, Sb 29, Fleskum herred, Ålborg amt

Undersøgelsen er foretaget af mus.insp. Erik Johansen, Ålborg Historiske Museum i 1976-77. (Kat. IA.02). 


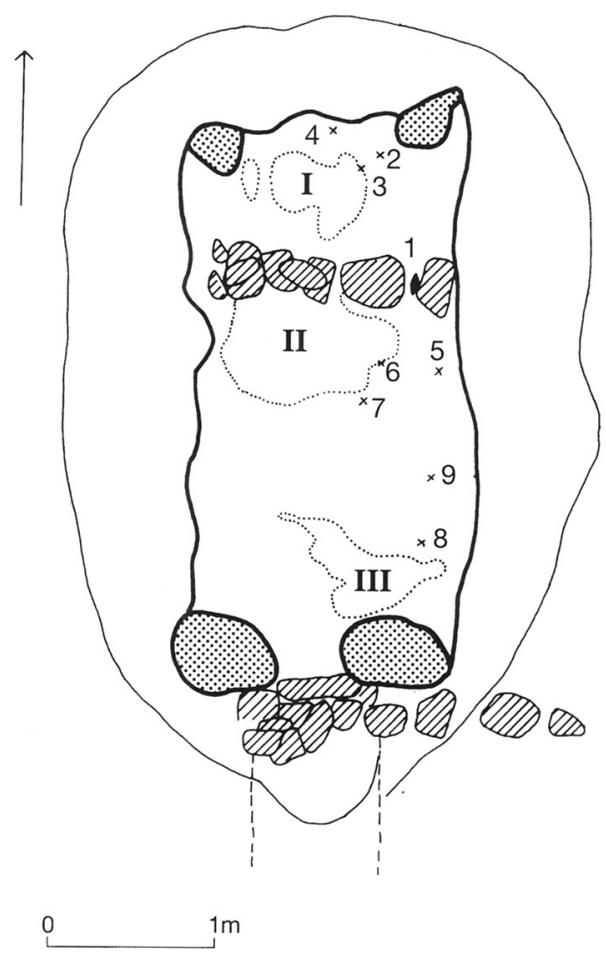

Fig. 14. Plan over den træbyggede gravkiste fra Sønder Tranders.

Plan of the wooden cist from Sonder Tranders.

Graven fandtes i en høj med en diameter på $21,5 \mathrm{~m}$, hvor der kun var bevaret op til $10 \mathrm{~cm}$ højfyld. Gravkisten er træbygget og består af gravrum, forrum og gang. Gravkisten er af type C2 (fig. 14).

Graven fandtes i pæreformet nedgravning på ca. $5 \times 3,2 \mathrm{~m}$, der var bredest i nordenden. Selve gulvniveauet la $0,69-0,73 \mathrm{~cm}$ under undergrundens overflade og var dybest i nordenden. Graven er rektangulær, N-S-orienteret. I hvert af gravens hjørner fandtes et stolpehul. De to nordligste var nedgravet nogle fă $\mathrm{cm}$ under gulvniveau, mens de sydlige var nedgravet $0,32-0,37 \mathrm{~m}$ under gulvniveau. Den sydvestlige var stenpakket.

Den nordligste del af kammeret udgøres af et 1,0 m langt gravrum, adskilt fra det 2,4 m lange forrum med en stenrække af flade sten, der lå direkte på undergrunden. Enkelte steder lå stenene i 2 skifter. Stenrækken kan have dannet fundament for en trætærskel. I gravkistens sydende har der været adgang til graven ad en smal, ca. $1 \mathrm{~m}$ lang slidskeagtig gang. Mellem gang og forrum var der anbragt en tærskelsten, en flad, lodretstående sten, nedgravet i undergrunden. Gangen var blokeret af marksten.

Ét sted i gravrummet og to steder i forrummet fandtes på gravbunden mørkere fedtede aftegninger, der må tolkes som rester af de gravlagte personer (fig. 14.I-III). I gravrummet ved ligspor I fandtes en 3,3 cm lang flækkepil med afbrudt spids (fig. 14.2), et 3,5 cm langt midterfragment (fig. 14.3) samt en hel flækkepil (fig. 14.4). Alle flækkepilene er af type D (Becker 1950). Ved ligspor II i forrummet fandtes ligeledes D-pile, et 2,9 cm langt stykke, to midterfragmenter på henholdsvis $2,9 \mathrm{~cm}$ og $2,1 \mathrm{~cm}$ (fig. 14.5-6) samt et spidsfragment på 1,8 cm (fig. 14.7). Mellem stenene i den tværgående stenrække fandtes en stridsøkse af type I4a med æggen mod syd (fig. 14.1). Denne økse skal sandsynligvis også knyttes til ligspor II. Ved ligspor III i forrummet fandtes et 2,9 cm langt midterfragment af en flækkepil (fig. 14.8) samt en hel flækkepil lidt derfra (fig. 14.9).

Stridsøksen kan dateres til yngre bundgravstid (Glob 1944, 62). En C-14 datering gav resultatet 2580-2350 f.Kr. (kal.) (20). 
Vesthimmerlands flyveplads hoj 2, Hvorvarp, Ulstrup sogn, Aars herred, Aalborg amt

Undersøgelsen er foretaget af forfatteren for Vesthimmerlands Museum, Aars i 1980. (Kat. IA.11).

Højen har en diameter på 19,5 m og en højde på knap $1 \mathrm{~m}$. (fig. 15) (21).

Gravkisten består af et gravrum og er af type E1. Gravrummet er rektangulært og måler 2,40x1,70 m orienteret SV-N $\varnothing$ med en $0,40 \mathrm{~m}$ bred åbning mod SV (fig. 16).

Anlægget har en væggrøft, der er 0,30-0,60 $\mathrm{m}$ bred og har en dybde på 0,52-0,73 $\mathrm{m}$ under gulvniveauet. Dybden er størst umiddelbart på begge sider af indgangen. Langs grøftens inderside findes et 5-10 cm bredt fyldskifte af løst gulbrunt sand, der stammer fra selve vægkonstruktionen. I groftens bund fandtes 15 ovale fordybninger, som er 0,35-0,60 lange og 0,20-0,35 m brede samt $0,06-0,21 \mathrm{~m}$ dybere end den øvrige grøft. Det er næppe stolpehuller, da fylden ikke adskiller sig fra grøften ligesom form og størrelse heller ikke taler for det. Der er snarere tale om ujævnheder, frembragt ved gravningen af grøften.

Spor efter formuldet træ findes $i$ et 5-8 $\mathrm{cm}$ tykt lag ind over kammeret i form af gulbrunt sand. Træsporene må stamme fra et sammenstyrtet kammer (fig. 17).

I kammerets bageste del fandtes et lerkar (fig. $16.1 \mathrm{og}$ 18.1), der daterer graven til senneolitikum periode A (22).

Graven er primær, hvilket fremgår af profil (fig. 17), hvor det ses, at det opgravede undergrundsmateriale er anbragt direkte på den gamle muldoverflade. Det fremgår desuden, at højen antagelig først er anlagt efter, at kammeret er faldet sammen, idet laget af formuldet træ (lag 5) strækker sig 1,2 $\mathrm{m}$ øst for graven og ligger direkte på den gamle muldoverflade under højfylden. I højfylden findes kun spredte rester af formuldet træ, som ikke kan sættes i forbindelse med kammeret.

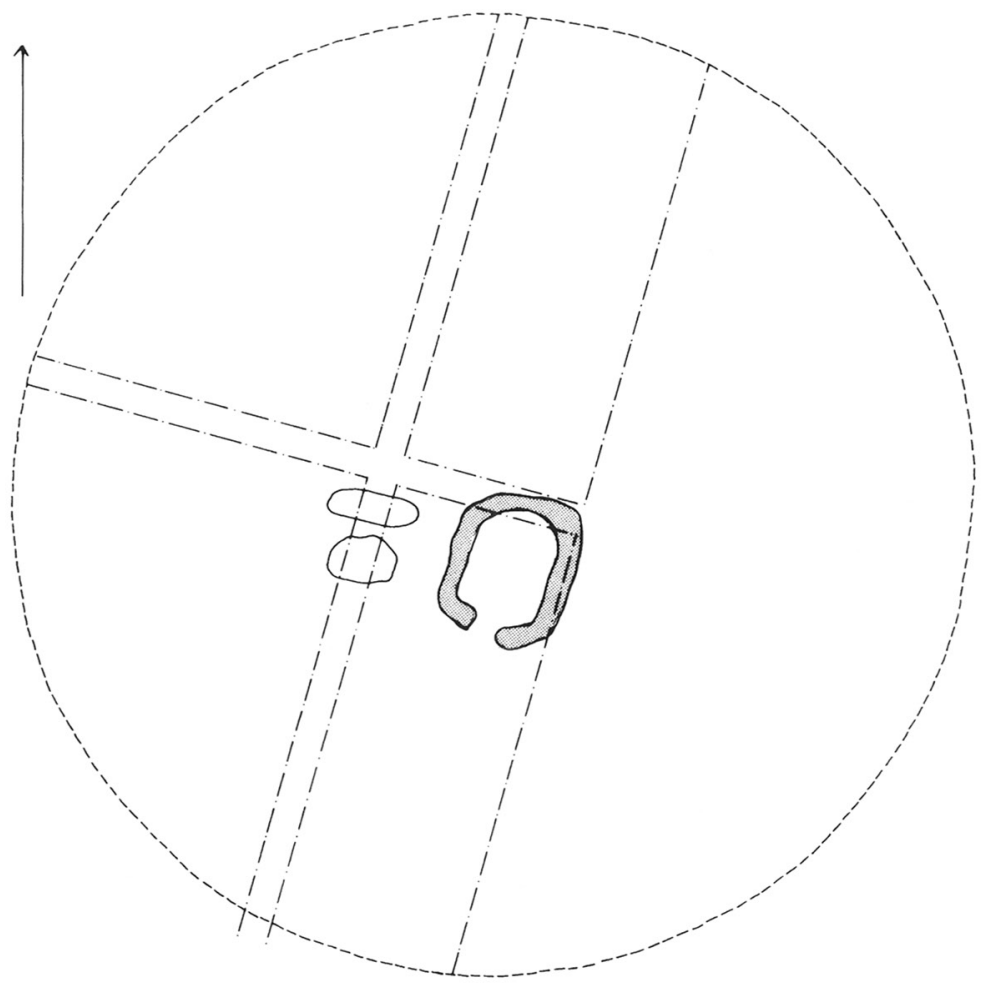

Fig. 15. Oversigtsplan over Vesthimmerlands Flyveplads Høj 2.

General plan of Vesthimmerlands landing field barrow 2. 


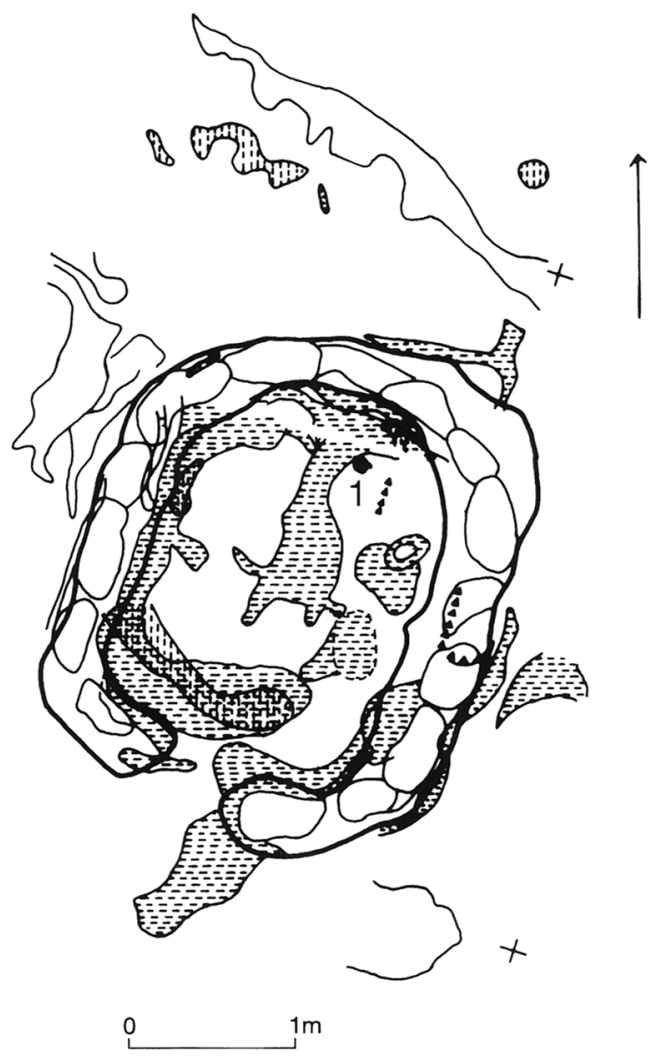

Fig. 16. Plan over træbygget gravkiste fra Vesthimmerlands Flyveplads Høj 2 med grøft, træspor og fund.

Plan of the wooden cist in Vesthimmerlands landing field barrow 2, showing footing trench, remains of wood, and finds.

Toftelund I, Enslev sogn, Sb 15, Gjerlev herred, Randers amt

Undersøgelsen er foretaget af Ole Schmidt for Kulturhistorisk Museum i 1982-83. (Kat. IA.21).

Højen var overpløjet med en diameter på 12-13 m. Højen er kun bevaret i en højde på 0,20 $\mathrm{m}$.

Gravkisten er træbygget og består af gravrum og gang (fig. 1.15). Gravkisten er af type D1. Gravrummet er rektangulært og måler 2,4x1,4 m. Gangen er $0,6 \mathrm{~m}$ lang og $0,55 \mathrm{~m}$ bred. Gravkisten er N-S-orienteret med indgang mod syd. Anlægget er omgivet af grøfter, der er 0,75-0,90 m brede og 0,25-0,35 $\mathrm{m}$ dybe. De er dybest i nordenden. Grofterne er dog nogle steder forstyrret af sekundære brandgrave og moderne nedgravninger.

I grøfterne fandtes 5 sikre stenpakkede stolpehuller, stående $\mathrm{i}$ den inderste del af grøften, $4 \mathrm{i}$ den nordlige gavl og en mod S $\varnothing$. Gavlstolperne gik 0,12-0,22 $\mathrm{m}$ under grøftens bund, mens den sidste kun gik $0,05 \mathrm{~m}$ ned. Grøfternes inderste del var stenfri og bestod af gråsort sand, blandet med lyst sand. Grøfternes ydre del var opfyldt af hovedstore sten, en dobbeltsidet kværn samt nogle heller, udhugget af en særegen, rød sandsten. Den indre stenfri del af grøften har antagelig rummet en trækonstruktion, støttet af sten.

I den inderste del af grøften fandtes flintafslag, 20 ravperler og 3 stykker keramik, deriblandt et fragment af et sikar. I selve kammerområdet var bevaret et tyndt kulturlag, heri fandtes 6 ravperler.

Graven dateres på grundlag af keramikken til enkeltgravstidens overgravstid. Dateringen understøttes af, at en hellekiste med keramik fra overgravstid i højens periferi er bygget af stenheller fra den samme røde sandsten, som fandtes i gravkistens grøft. 
Rold, Rold sogn, Hindsted herred, Aalborg amt

Undersøgelsen er foretaget i 1947 af gdr. Regnar Pedersen, hos hvem fund og udførlig beretning befinder sig. (Kat. IA.04)

Der var intet uforstyrret højfyld tilbage og højens diameter kunne ikke fastlægges.

Gravkisten er træbygget og består af et gravrum (fig. 1.12). Gravkisten er af type E2.

Ved undersøgelsen fandtes et rektangulært, nærmest N-S-orienteret grøftanlæg med de indre mål 1,50x2,60 m. Grøften var 0,40 m bred og 0,35-0,60 m dyb, undtagen i den vestlige del af den sydlige grøft. Her var dybden kun $0,18 \mathrm{~m}$. Mellem grøfterne fandtes i kistens nordlige del et $1,50 \times 0,90 \mathrm{~m}$ stort område med et 5-10 cm tykt lag af trækulsblandet jord, dækket af en ca. $10 \mathrm{~cm}$ tyk stenpakning af op til nævestore sten. flint.

Mellem stenpakningen og det trækulsholdige lag fandtes en fliget pilespids med bred basis af

Anlægget må på grundlag af pilespidsen dateres til senneolitikum.

Anlægget er af Lomborg opfattet som tomten af en stenbygget gravkiste, hvor sidestenene er fjernet fra grøften (Lomborg 1973, 205). Denne tolkning er næppe holdbar, idet grøften er yderst regelmæssig og uden stenspor, ligesom der ikke var tegn på, at grøften var forstyrret i nyere tid.

I øvrigt fandtes der henholdsvis $1,5 \mathrm{og}$ 1,0 $\mathrm{m}$ NØ for anlægget 1 ravperle og fragmentet af en flintdolk (type IB). Flintdolken er af Lomborg anført som inventar i graven, hvilket, fundforholdene taget $\mathrm{i}$ betragtning, må anses for yderst usikkert.

Kovhøj, Store Arden sogn, Hindsted herred, Aalborg amt

Undersøgelsen er foretaget i 1960 af gdr. Regnar Pedersen, hos hvem fund og en udførlig beretning befinder sig. (Kat. IA.05).

Fundet er gjort i en helt udpløjet høj. Der var intet højfyld tilbage og højens diameter kunne ikke bestemmes.

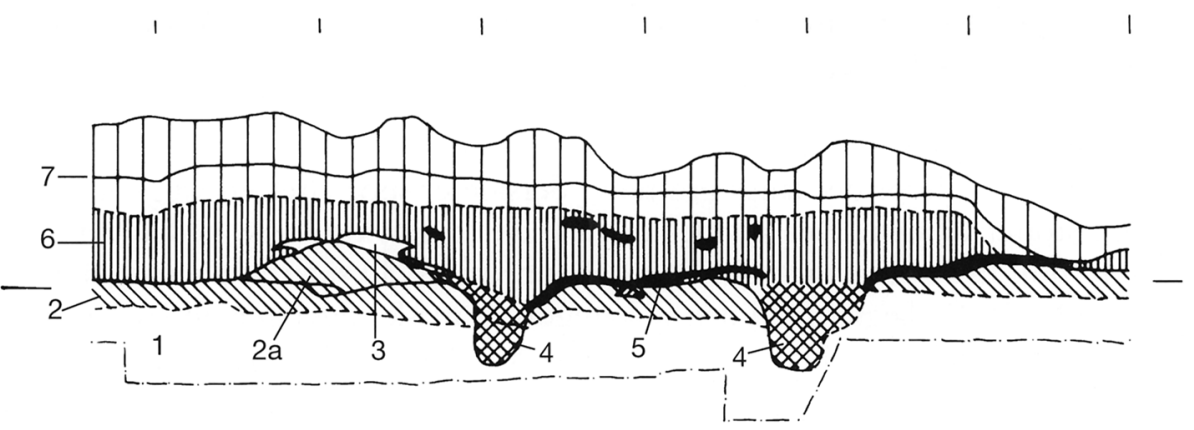

Fig. 17. Profiltegning af et omtrent $\varnothing-\mathrm{V}$-snit gennem gravkisten fra Vesthimmerlands Flyveplads Høj 2. 1. Undergrundsmateriale. 2. Oprindeligt muldlag. 2a. Opgravet muldlag. 3. Opgravet undergrundsmateriale. 4. Væggrøft. 5. Formuldet træ. 6. Højfyld. 7. Moderne muldlag. Den uregelmæssige overflade skyldes to vejspor tværs over højen.

Fig. 18. Fund fra gravkisten fra Vesthimmerlands Flyveplads Høj 2: 1. Lerkar.

Finds from the cist in Vesthimmerlands landing field barrow 2: 1. Pot.
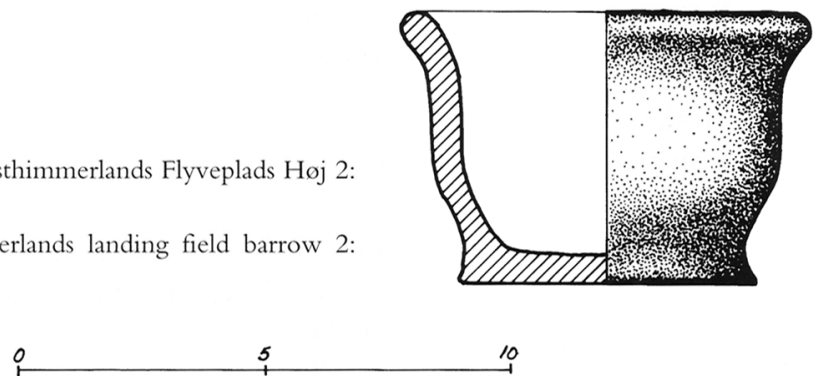
Gravkisten er træbygget og består af et gravrum. Gravkisten er af type E (fig. 1.11).

Ved undersøgelsen fandtes en U-formet grøft, der afgrænsede et område på 2,5 x 0,8-1,1 m. Anlægget er N-S-orienteret med åbningen mod syd. Grøften er 0,75-0,90 m bred og dybden er 0,8-1,0 $\mathrm{m}$ under undergrundens overflade. Grøften var pakket med sten, der varierede fra "håndstore til ca. dobbelthovedstore«. "Ved grøftens inderside var der flere steder trækul, der lignede rester af pæle, som var tildannet ved hjælp af ild. De synes at have stået på højkant med en svag hældning ind mod gravens midte«. I forlængelse af den vestlige grøft fandtes et ældre fyldskifte af muldblandet undergrundssand uden sten.

I gravrummet, direkte på undergrunden, fandtes spidsen af en flintdolk med parallelhugning, en flække samt nogle få sideskår. I pløjelaget over grøften fandtes endnu et fragment af den samme flintdolk, hvis spids fandtes i gravrummet. Desuden fandtes der keramik to steder i grøften. Lerkarskårene i gravrummet kan ikke dateres nærmere end enkeltgravstiden eller senneolitikum (23).

Anlægget dateres af flintdolken til senneolitikum A (Lomborg 1973, 39f og 64ff).

\section{De træbyggede gravkisters konstruktion og funktion}

I det følgende vil gravkisternes konstruktion og funktion blive analyseret med udgangspunkt i de 11 beskrevne træbyggede gravkister og de øvrige i katalog I. De typebestemmelige er samlet i katalog IA. De dårligere bevarede, eller på anden måde usikre, som ikke kan typebestemmes samt de lukkede kamre, er samlet i katalog IB.

\section{Konstruktion}

På trods af anlæggenes meget individuelle karakter kan konstruktionsprincipperne samles i fire kategorier:

1) Gravkister, nedgravet $i$ undergrunden og forsynet med 4 hjørnestolper, men uden en grøft i konstruktionen. (IA.2, 29).

2) Gravkister, hvor der langs grøftens yderside er spor efter en vægkonstruktion, støttet af sten. Det skyldes uden tvivl at gravkisten er nedgravet i en ældre høj, hvor vægkonstruktionen er anbragt op ad siderne på nedgravningen (IA.12). Beslægtet med denne kategori er måske også graven IA.19, men her er iagttagelserne ikke særlig detaljerede. Der er ikke påvist vægstolper i denne kategori.

3) Gravkister med stolpehuller i væggrøften. I seks tilfælde er der påvist sikre stolpehuller i grøften (IA.6, 21, 22, 27, IB.5 og IB.6). I disse gravkister med stolpehuller er der i ingen af tilfældene fundet spor af planker langs grøftens sider. Stolperne er i et enkelt tilfælde støttet af sten (IA.21).

4) Gravkister med væg af lodrette planker i grøftens inderside. Det er den mest almindelige form for vægkonstruktion, som er påvist i ti tilfælde (IA.1, $3,7,8,9,10,11,13,14,17)$ samt et usikkert (IA.5). Trækonstruktionen kan i enkelte tilfælde være støttet af sten (IA.1, 5 og 14).

Der kan ikke dokumenteres nogen systematisk, kronologisk eller geografisk forskel i konstruktionerne. Udover ovennævnte forhold omkring væegkonstruktioner er der gjort andre iagttagelser. Loftet er dokumenteret i 2 tilfælde (IA.10 og 12). Her synes det at have været fladt. Med et fladt loft vil konstruktionen også svare til de stenbyggede gravkisters. I de tilfælde, hvor der kan iagttages hældende planker i væggrøfterne, er hældningen så lille, at en tænkt teltformet bygning ville blive omkring $3 \mathrm{~m}$ høj, hvilket ville være helt urealistisk. 
I fire tilfælde, hvor højen har stået op omkring gravkisten i dennes funktionstid, er adgangsforholdene dokumenteret, nemlig Vesthimmerlands Flyveplads høj 1 og 3 (IA.10, 12), Keldgård 4 (IA.14) samt Sønder Tranders (IA.02). Her er adgangen sket fra et sted på højoverfladen og ned til gravkisten og ikke ude fra højperiferien. Det samme påpeges af Ebbesen for de stenbyggede gravkisters vedkommende (Ebbesen 1985, 8) (24).

I otte tilfælde er gravkisterne opdelt i gravrum, forrum eller gang ved særlige konstruktioner. I et tilfælde sker det med en stenrække (IA.2), mens det i syv tilfælde sker med en grøft, der må repræsentere en skillevæg eller en trætærskel (IA.6, 7, 8, 10, 13, 21 og IB.06). I andre tilfælde antydes en funktionsopdeling indirekte ved en brolægning eller udbredelsen af formuldet træ og trækul (IA.4, 14, 19), men en veldokumenteret opdeling af kammeret i gravrum og forrum findes udelukkende i bundgravstid. Antydninger af opdelingen fortsætter dog op i overgravstid og senneolitikum A.

I to tilfælde er det påvist, at den bageste del af gravkisten er forsænket lidt i forhold til den forreste del (IA.2 og IA.14). En lignende iagttagelse er gjort i de stenbyggede gravkister fra Kirkebjerghøj (IIA.40) og Kobberup (IIA.049).

I ét tilfælde er der fundet spor af en trækiste (bulkiste), nemlig i Glenstrup (IA.22). Tilsvarende er der i den stenbyggede gravkiste i Kobberup (IIA.49) påvist tilstedeværelse af en plankekiste, dækket af et lag af hasselgrene. Påvisningen af hassel i den træbyggede gravkiste fra Keldgård 4 (IA.14) antyder, at også her kan den døde være dækket af grene.

\section{Funktion}

Den enkelte træbyggede gravkistes funktionstid er, som følge af byggematerialets holdbarhed nødvendigvis, ret tidsbegrænset. Det er nok ikke sandsynligt, at den har fungeret meget mere end en generation, højst 20-30 år. Det er derfor påfaldende, at der i flere af dem er dokumenteret spor efter, ikke alene flere lig, men også af, at begravelserne er foretaget i flere omgange. Således fandtes der i Drenghøj 3 lig (IA.1), i Sdr. Tranders 3 lig (IA.2), i Ø. Hornum mindst 3 lig (IA.6), i Volstrup 4 (IA.7), i Kragehøj 8 (IA.8), i Koldkur 3 eller 4 lig (IA.16) og i Demstrup 4 lig (IA.20). Både i Drenghøj og i Volstrup er det dokumenteret, at begravelserne er sket i mindst to omgange. I andre tilfælde tyder gravgodsets placering også på flere begravelser, således Keldgården høj 4 med 2 begravelser (IA.14), Hald med 3 eller 4 (IA.17) og Kjeldagerhøj med mindst 2 (IA.19).

Når den enkelte træbyggede gravkistes brugstid har været relativ kort, og der i så mange af gravkisterne er påvist flere begravelser, må det anses for sandsynligt, at anlæggene også er bygget som fællesgrave til genbrug. Dette er i overensstemmelse med forholdene $\mathrm{i}$ en enkelt stenbygget gravkiste. I Gjerrild (IIA.56), hvor der kan dokumenteres gentagne begravelser fra enkeltgravskulturen og i Kobberup (IIA.49), hvor der også er foretaget to begravelser, enten samtidig eller med kort mellemrum.

Disse iagttagelser er desuden i fuld overensstemmelse med den praksis, der kan iagttages ved brugen af tragtbægerkulturens megalitgrave i enkeltgravskulturen og senneolitikum, samt anvendelsen af gravkisterne fra enkeltgravskulturen i senneolitikum. 
Med hensyn til de dødes placering og deres køn er der fem af fundene, der giver oplysninger. I Volstrup (IA.7) synes alle at have ligget $\varnothing-\mathrm{V}$ orienterede med hovedet mod vest. Gravgodset tyder på, at alle var mænd. I Kragehøj (IA.8) fandtes traditionelle mandsgenstande ved de lig, som havde hovedet i vest. Desuden fandtes 3 lig med hovederne i øst. Det ene kunne der ikke knyttes gravgaver til. Ved det andet fandtes en større samling ravperler og ved det tredje fandtes også mange ravperler samt 3 flækkepile. Bortset fra flækkepilene er der indicier for, at kvinderne har ligget med hovedet $\mathrm{i} ø$ øs.

I Ø. Hornum (IA.6) lå 2 stridsøkser og 3 flintøkser i vestsiden. Bortset fra en stridsøkse midt for kammerets bagvæg peger iagttagelserne også her på, at mænd har ligget med hovedet i vest. I Demstrup (IA.20) viser tandemalje og gravgaver, at de døde har ligget $\varnothing-\mathrm{V}$-orienterede, 2 mænd med hovedet mod vest og 2 kvinder med hovedet mod øst.

Så bortset fra, at de døde har ligget i rygleje, i hvert tilfælde i Volstrup og Kragehøj, hvor skeletsporene var bevaret, svarer placeringen til den, der kendes fra enkeltgravene.

Forholdet til den høj, hvori gravkisterne er fundet varierer en del. I tre tilfælde kunne det påvises, at kammeret er anlagt, anvendt og faldet sammen inden højen bygges på stedet (IA.11, 17, 27). I syv tilfælde kan det dokumenteres, at kammeret har fungeret, mens højen har stået op omkring det (IA.6, 7, 8 ,10, $12,13,14)$. I tre af disse tilfælde er kammeret anlagt i en ældre høj (IA.12, 13, $14)$.

I tre tilfælde er de træbyggede gravkister fundet flere sammen i højgrupper. Det gælder ved Volstrup (IA.6-8), ved Keldgården (IA.12, IA.14 og IB.5-6) og på Vesthimmerlands Flyveplads (IA.10-12). Dertil kan føjes, at der i de tilfælde, hvor de tilsyneladende ligger alene, ikke er foretaget undersøgelser i eventuelle nabohøje.

Denne forekomst af flere gravkister i en højgruppe er kun dokumenteret i et tilfælde blandt de stenbyggede gravkister, nemlig i Tandrup (IIB.35-36). Men det kan bero på en tilfældighed, da der ikke i andre tilfælde er foretaget systematiske undersøgelser af nabohøjene til højene med stenbyggede gravkister.

De træbyggede gravkister optræder i samme områder, som de stenbyggede. Gravgods eller andre forhold tyder ikke på, at det er sociale eller kønsbestemte forhold, der har bestemt valget af byggemateriale. Det synes således nærliggende at forestille sig, at man har benyttet det byggemateriale, der var nemmest tilgængeligt i en given situation. Træ har nok, trods skovrydninger, været tilgængeligt i hele perioden, mens store sten måske er dukket mere tilfældigt op.

\section{Typologi og kronologi}

\section{Typologi}

En typologisk analyse af både de træbyggede og de stenbyggede gravkister resulterer i den følgende opdeling, hvori alle blot nogenlunde velbevarede gravkister har kunnet placeres. Målet har desuden været at fokusere på de kronologisk betingede elementer. Her har det vist sig, at en analyse af formerne af de tre "rum«, gravrum, forrum og gang gav et frugtbart udgangspunkt (fig. 19). 


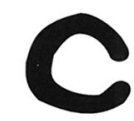

A1

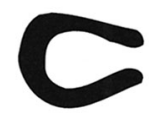

A2a

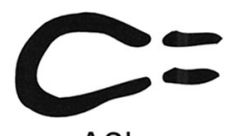

A2b

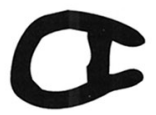

A2c

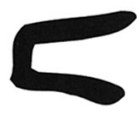

A3a

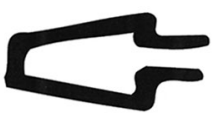

A3b

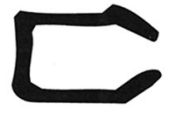

B1a

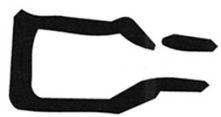

B1b

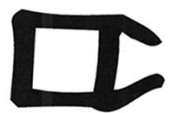

B2

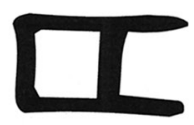

C1

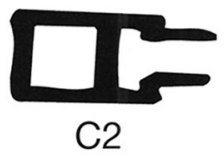

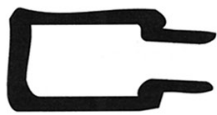

D1

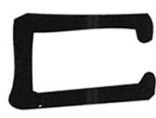

D2

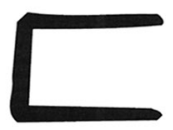

E

Fig. 19. Skematisk oversigt med typer og undertyper.

Scheme of types and subtypes. 
Type A: Gravkister med cirkulart, ovalt, pereformet eller trapezformet gravrum. Typen kan have forrum eller gang (25). Der kan udskilles 6 undertyper: A1, A2a, A2b, A2c, A3a og A3b.

A1: Type A af cirkulær form. Hertil henføres 2 træbyggede anlæg (IA.27, 28).

A2: Type A med pære- eller trapezformet gravrum, hvor indgangen findes i den smalleste ende. Der optræder 3 varianter:

A2a: Type 2 uden gang eller forrum. Hertil henføres 5 træbyggede anlæg (IA. 12, 14, 25 og 26) og 20 stenbyggede (IIA.7, 8, 17, 21, 25, 29, 32, 33, $35,39,40,52,53,56,82,86,88,89,90,91)$.

$A 2 b$ : Type 2 med gang, men uden forrum. Hertil henføres 11 stenbyggede anlæg (IIA.5, 23, 36, 37, 45, 47, 48, 49, 51, 58, 66).

A2c: Type 2 med forrum, men uden gang. Hertil henføres 2 stenbyggede anlæg (IIA.44, 54).

A3: Type A med pære- eller trapezformet gravrum, hvor indgangen findes i den bredeste ende. Der optræder 2 varianter:

A3a: Type A3 uden gang eller forrum. Hertil henføres 3 stenbyggede anlæg (IIA.33, 60, 61).

A3b: Type A3 med gang, men uden forrum. Hertil henføres et træbygget anlæg (IA.10) og et stenbygget (IIA.02).

Type B: Gravkister med 5-eller 6-kantet gravrum eller et rektangulart til tondeformet gravrum og et trapezformet forrum. Typen kan have gang (26). Der kan udskilles 3 undertyper (B1a, B1b og B2):

B1: Type $B$ uden forrum. Der optræder 3 varianter:

B1a: Type B1 uden gang. Hertil henføres 3 træbyggede anlæg (IA.3, 15, 16) og to stenbyggede (IIA.11, 84).

B1b: Type B1 med gang. Hertil henføres 1 træbygget anlæg (IA.17) og 2 stenbyggede (IIA.30, 43).

B2: Type B med forrum. Hertil kan henføres 3 træbyggede anlæg (IA.7, 8, 13) og 1 stenbygget (IIA.34).

Type C: Gravkister med rektangulart eller tondeformet gravrum og rektangulart forrum. Typen kan have gang (27). Der kan udskilles 2 undertyper:

C1: Type C uden gang. Hertil henføres 1 træbygget anlæg (IA.6) og 3 stenbyggede (IIA.1, 19, 87).

C2: Type C med gang. Hertil henføres 1 træbygget (IA.2) og 1 stenbygget (IIA.20).

Type D: Gravkister med rektangulart eller tondeformet gravrum. Indgangen er smallere end kammerets bredde. Typen kan have gang (29). Der kan udskilles 2 undertyper:

D1: Type D med gang. Hertil henføres 3 træbyggede anlæg (IA.19, 21 og

22) samt 6 stenbyggede (IA.6, 27, 31, 50, 57, 59).

D2: Type D uden gang. Hertil henføres 7 træbyggede anlæg (IA.4, 9, 11, 18, 20, 23, 24) og 7 stenbyggede (IIA.18, 22, 24, 26, 38, 41 og 42).

Type E: Gravkister med rektangulart eller tøndeformet gravrum uden gang eller forrum. Indgangen har samme bredde som kammeret (29). Hertil henfores to træbyggede 
anlæg (IA.5, og 29) samt 35 stenbyggede (IIA.3, 4, 9, 10, 12, 13, 14, 15, 16, 28, $46,55,62,63,64,65,67,68,69,70,71,72,73,74,75,76,77,78,79,80,81$, $83,85,92$ og 93).

Selve den typologiske opdeling er søgt gjort så eksakt som muligt. Men i praksis kan der i nogle tilfælde alligevel være problemer (30).

Dateringen af gravtyperne, som er foretaget på grundlag af inventaret i de træbyggede gravkister samt C-14 dateringerne, som præsenteres i skemaet fig. 22.

Type A1 dateres til yngre undergravstid på grundlag af lerkar af Globs type C1 i 2 træbyggede gravkister (IA.27 og 28).

Type A2 dateres til ældre bundgravstid på grundlag af stridsøkser type $\mathrm{F}$ og $\mathrm{G}$ og små ravringe samt $6 \mathrm{C}-14$ dateringer mellem 2150 og 2040.

Type A3 er fătallige, men et enkelt træbygget anlæg indeholdt en lille ravring fra xldre bundgravstid.

Type $B$ dateres til ældre bundgravstid på grundlag af stridsøkser type $\mathrm{H}$ samt fire C-14 dateringer mellem 2100 og 1940. Måske afspejler forskellen mellem øksetyperne fundet $\mathrm{i}$ henholdsvis A- og B-gravene en tidsmæssig forskel, skønt Glob (Glob 1944, 40f) mener, at øksetyperne er samtidige.

Type $C$ er fătallige, men to træbyggede anlæg dateres til yngre bundgravstid på grundlag af I-økser og en C-14 datering på 2030.

Type D1 dateres på keramik fra to træbyggede gravkister til overgravstid. Graven fra Keldagerhøj (IA.19) indeholder udover overgravskeramik også senneolitisk keramik (fig. 20), der peger på en datering på overgangen mellem overgravstid og senneolitikum.

Type D2 dateres i to tilfælde til overgravstid på keramik, og i to andre tilfælde er dateringen senneolitikum A. Der er seks stenbyggede, der på stridsøkser eller keramik dateres til overgravstid.

Type $E$ dateres $\mathrm{i}$ et tilfælde $\mathrm{i}$ en træbygget gravkiste til senneolitikum A på grundlag af en flintdolk.

\section{Kronologi}

Dateringerne af de træbyggede gravkister er testet mod de stenbyggede gravkister i skemaet fig. 21, hvor det viser sig, at de typebestemmelige stenbyggede gravkister indeholder inventar, der er samtidig med eller yngre end den periode, hvori de skal placeres efter ovennævnte typologiske datering. Dermed må den typologiske analyses kronologiske relevans være bekræftet.

Der er således dokumenteret en udvikling fra en cirkulær type (A1) i yngre undergravstid over de pærer/trapezformede (A2-3) og de 5-6 kantede (type B) i ældre bundgravstid frem til de rent rektangulære former, hvoraf de ældste (type C) er fra yngre bundgravstid, og den senere (type D1) fra overgravstid har gang, mens udviklingen afsluttes med typer uden forrum eller gang (type E) fra senneolitikum A. Der er indtil videre ingen dokumentation for, at byggeriet er fortsat efter denne periode.

Det er bemærkelsesværdigt, at typerne afløser hinanden i hurtig rækkefølge og bortset fra type D2, og måske D1, der kan dateres til både overgravstid og senneolitikum A, er der ingen af gravtyperne, der bygges i mere end én underperiode. 

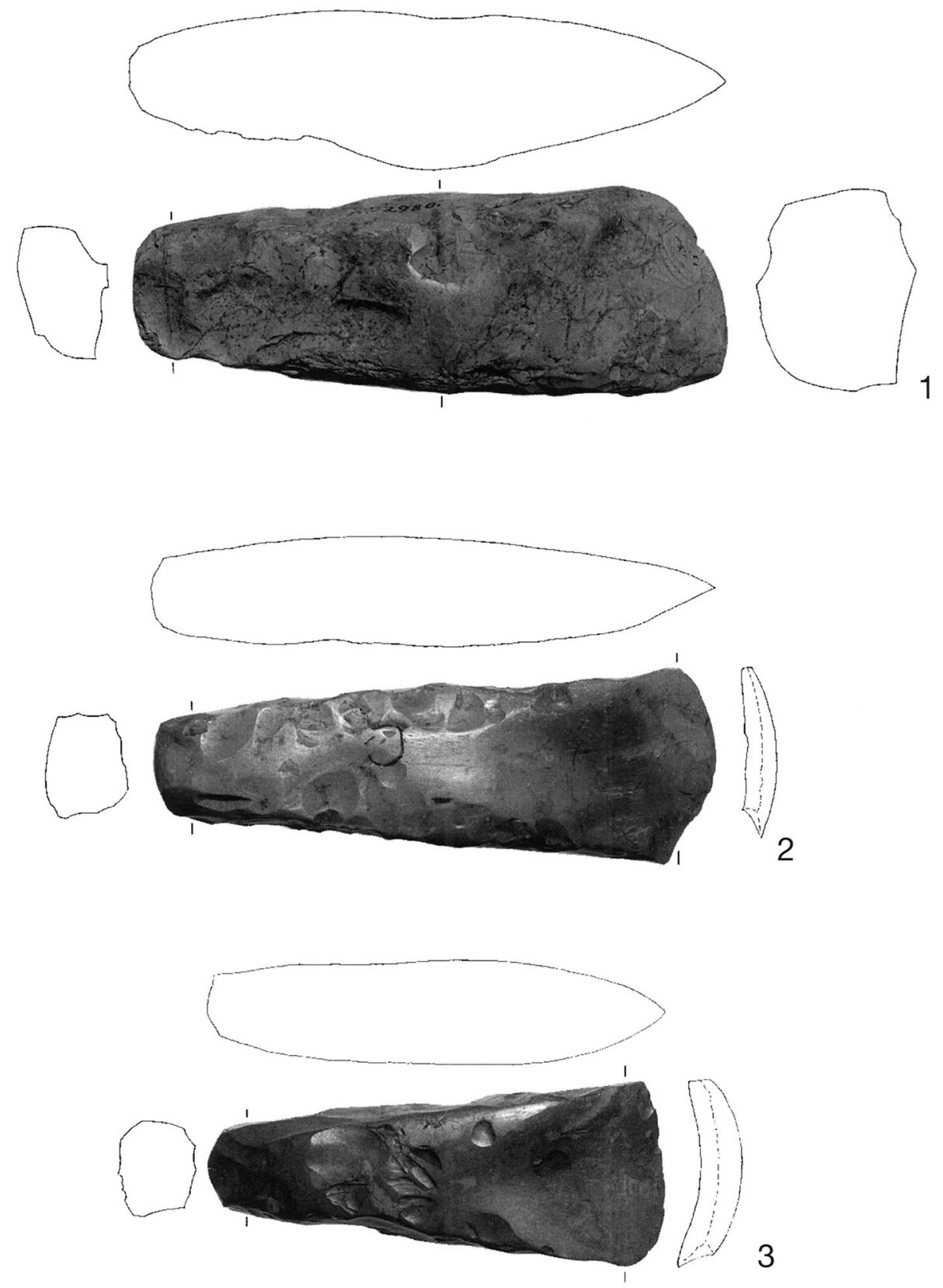

Fig. 20. Fundene fra Keldagerhøj: 1-2. Tyknakkede flintøkser. 3-4. Hulæggede tyknakkede flintøkser. 5-7. Keramikskåle. Økserne nr. 1 og 2 er typer, der tilhører enkeltgravskulturen, mens 3 og 4 desuden også kunne tilhøre senneolitikum. Keramikken nr. 5 og 6 er klare senneolitiske typer, mens nr. 7 er et unikt stykke, der p.g.a. godstypen og bølgeornamentikken nærmest skal placeres i enkeltgravskulturen.

The finds from Keldagerhøj: 1-2. Thick-butted flint axe. 3-4. Thick-butted gouges. 5-7. Bowls. Axes 1 and 2 are types belonging to the Single Grave Culture, but 3 and 4 could equally be Late Neolithic. Pots 5 and 6 are clear Late Neolithic types, while 7 is unique, but from its biscuit and wave ornament would perhaps best be placed in the Single Grave Culture. 


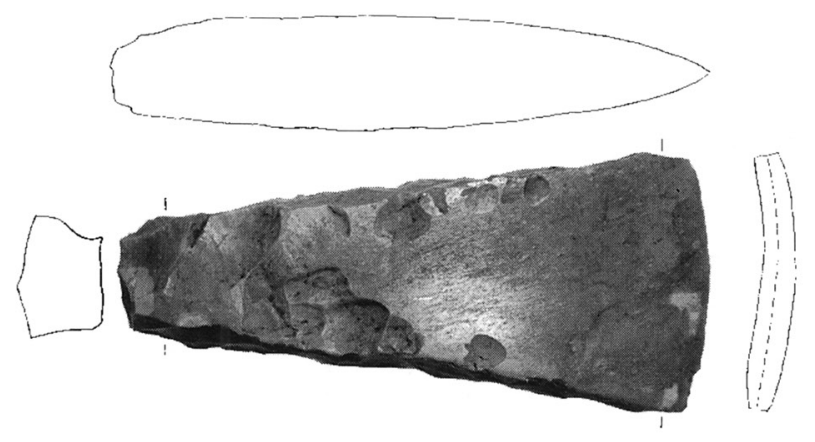

4
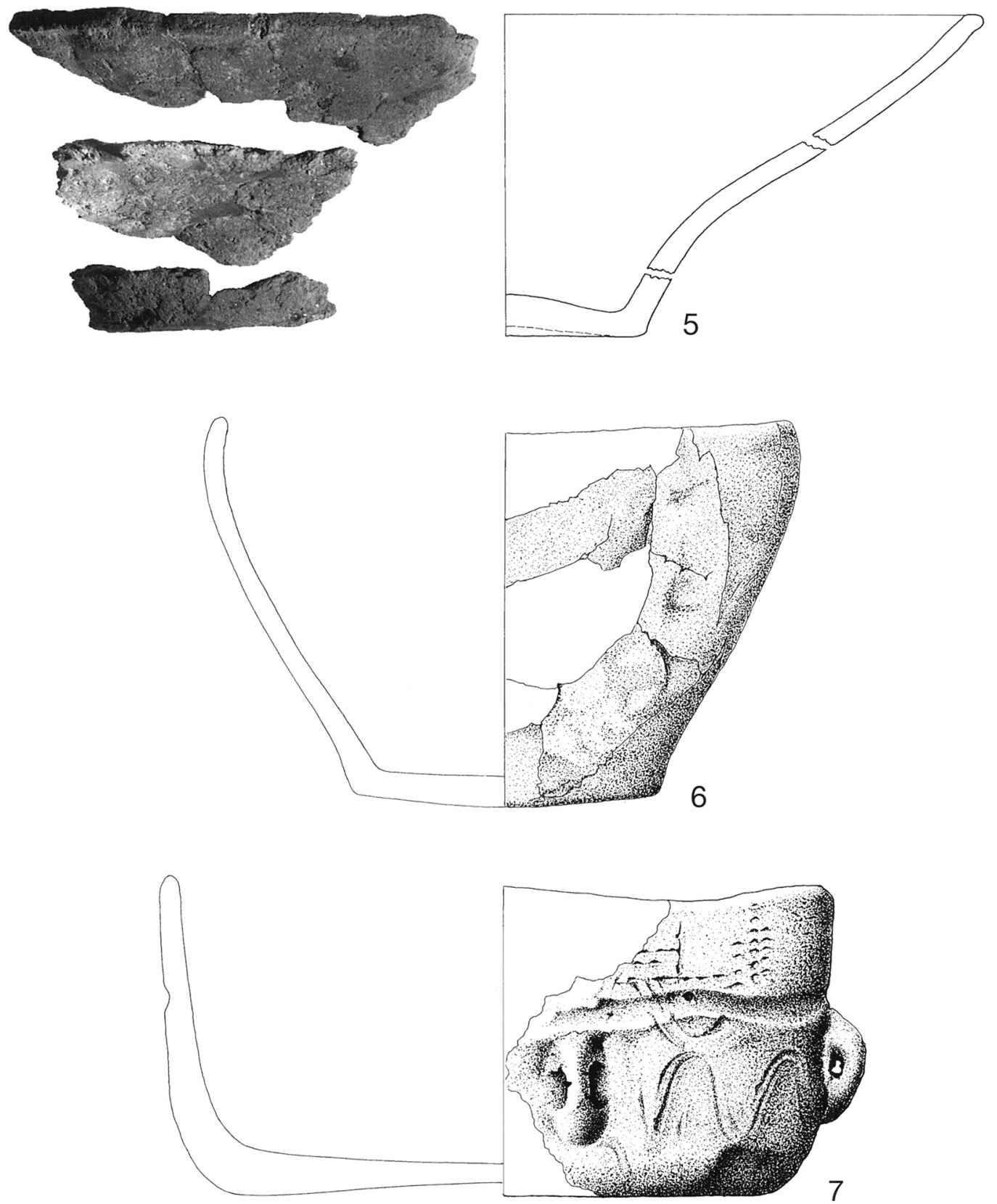


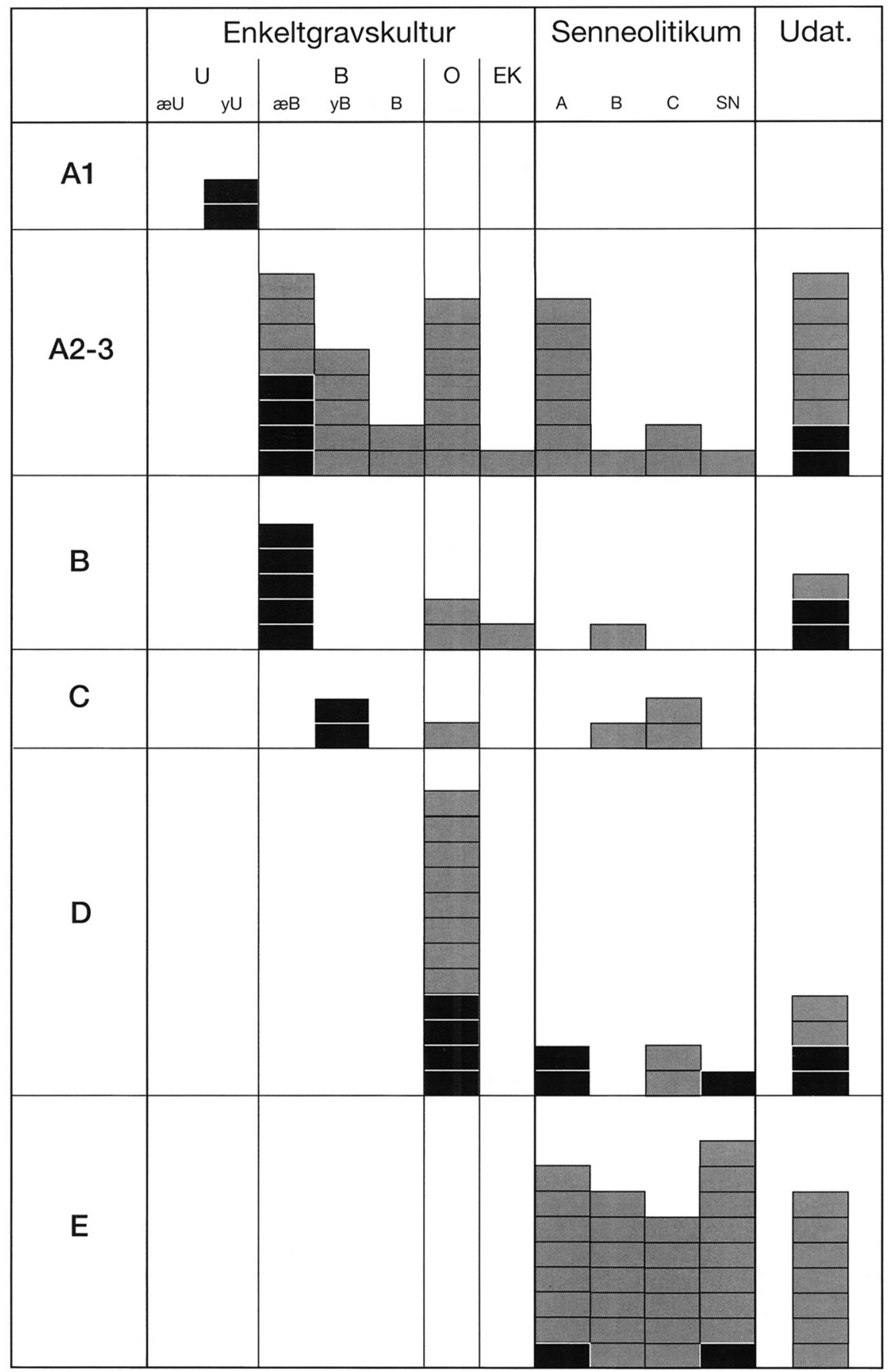

Fig. 21. De enkelte gravkisters kronologiske og typemæssige placering.

Chronology and typology of the cists. 


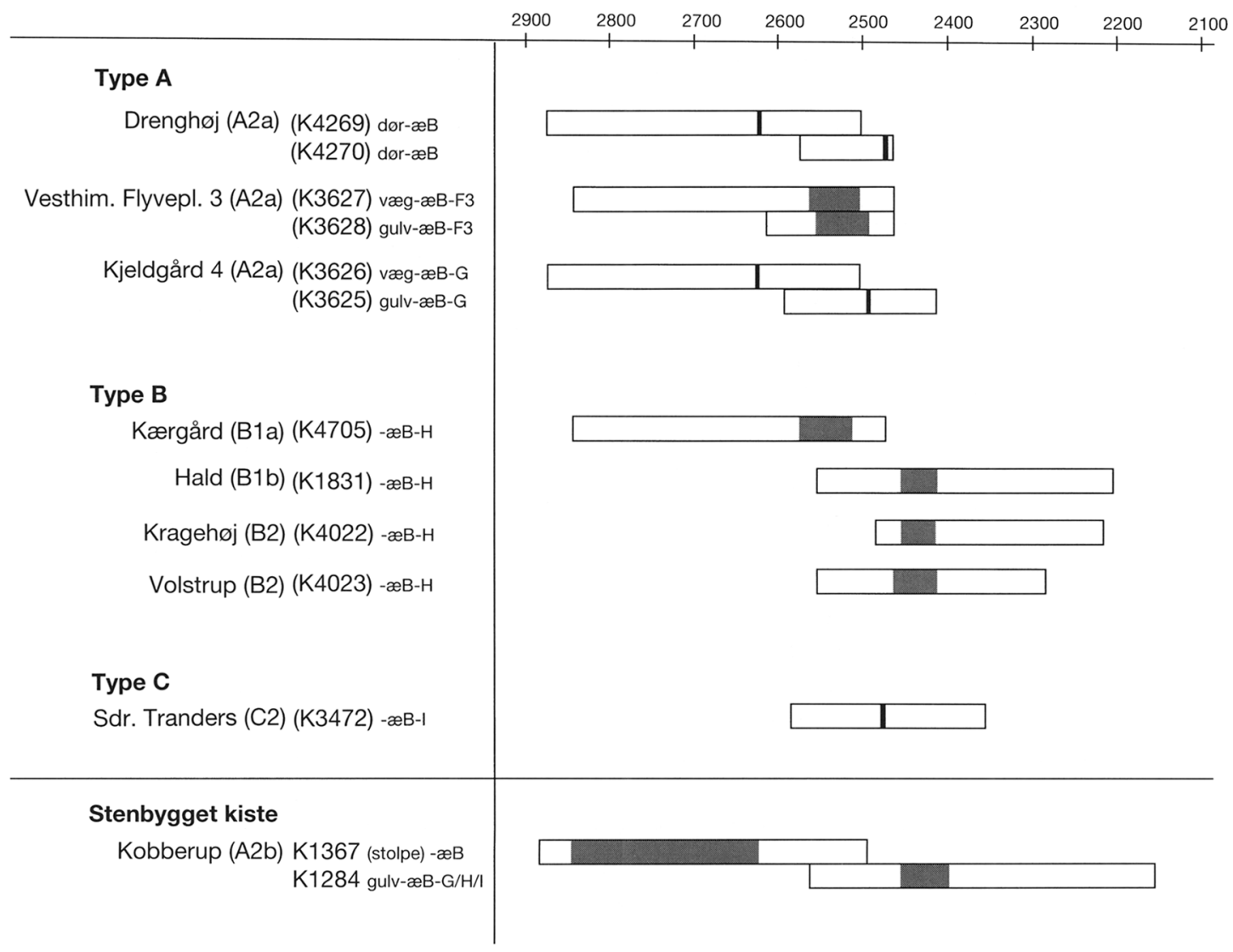

Fig. 22. C-14 dateringer af træbyggede gravkister.

Radiometric datings of wooden cists.

Kulstof-14 dateringerne er afbildet i fig. 22. Det fremgår at tre grave af type A er dateret med to dateringer hver (Kat. IA.01, 12 og 14). Der er en betydelig spredning, der for de to sidstnævnte graves vedkommende kan opdeles i eg fra vægkonstruktionen og træ fra gulvet. De yngste dateringer fra gulvet ligger på 2610-2410. Inden for samme område ligger den yngste datering fra Kat. IA.01.

Type B er dateret i fire tilfælde (Kat. IA.03, 17, 08, 07). De tre sidstnævnte ligger mellem 2550-2200, mens den forste er betydeligt ældre.

Type C er kun dateret i et tilfælde med resultatet 2580-2350.

Sammenfattende kan man således konkludere, at der hvor der foreligger et større antal C-14-dateringer bekræftes de typologiske dateringer, nemlig tidsforskellen mellem A-og B-typerne.

Orientering

Gravkisternes orientering er afbildet på fig. 23). Type A1's indgang er vendt mod vest (der kendes dog kun to eksemplarer). 
Type A2-3, B og C's indgange er overvejende sydligt orienterede med nogle mod en mere østlig orientering og kun fire, der skiller sig ud ved en orientering mod vest eller sydvest.

Type D har en tendens til en større spredning både mod øst og vest, helt om til VNV. Men orienteringen er helt overvejende sydlig.

Type E har en endnu større spredning mod alle retninger, men med en klar overvægt mod øst, men også en del mod syd. Den overvejende østlige orientering knytter sig til gravkisterne på de danske øer, mens der i det vestlige Limfjordsområde findes en stor spredning i orienteringen.

Der synes at være en tendens til, at det er de brede grave, der er orienteret mod syd, mens de smalle er orienteret mod øst eller vest. De N-S-orienterede varierer i bredde $0,5-4,0 \mathrm{~m}$ med et middeltal på 1,7, mens de $\varnothing-\mathrm{V}$-orienterede varierer fra 0,5-2,2 m med et middeltal på 1,1 m. Tendensen er dog ikke statistisk signifikant, idet spredningen i bredden er stor uanset orienteringen.

Fænomenet kan tolkes sådan, at det tilsyneladende har været betydningsfuldt, at liget blev orienteret $\varnothing-\mathrm{V}$, mens der samtidig har været faktorer, der slører billedet.

\section{Trabyggede gravkister uden for Danmark}

De stenbyggede gravkister, som de her er defineret, er kendt over store dele af Nord- og Vesteuropa. Mange af dem er udaterede eller dårligt dokumenterede i publikationerne, specielt hvad angår en eventuel indgang. Det vil derfor kræve omfattende studier af primærmaterialet at udskille alle periodens gravkister. I nogle områder kan de desuden have stor lighed med ældre gravtyper (f.eks. Fischer 1956; Behrens \& Schröter 1980). Der skal derfor langt fra tilstræbes at give en fuldstændig oversigt.

På grundlag af det tilgængelige publicerede materiale har jeg eftersøgt så mange træbyggede gravkister som muligt. Blandt de stenbyggede er særlig type A eftersøgt, samt eksempler på så mange forskellige typer som muligt. På den baggrund skal følgende fund ses som en stikprøve:

A-typen kendes uden for Danmark kun i form af undertypen A2a:

Træbyggede pæreformede anlæg (type A2a) fra Holland: Eext (Van Giffen 1930 bd 1, 140 og bd 2 fig. 104) og Putten (Van Giffen, Addink-Samplonius \& Glasbergen 1971). Sidstnævnte kan ved hjælp af keramik dateres til en fase af Hollands snorekeramisk kultur, der svarer til dansk ældre bundgravstid og C-14dateres til $2145 \pm 110$ f.Kr. (ukal.), mens den fra Eext kun kan dateres til snorekeramisk kultur i almindelighed.

Stenbyggede anlæg af type A2a, kendes i 4 tilfælde fra Tyskland: Putlos, Kr. Oldenburg. (Schwantes 1939, 248 og fig. 320-21), Heiligenhafen (Struwe 1955, 77 fig. 9), Warringholz (Struwe 1955, 74, Pl 4.1-3; Katalog no 634) og Dölauer Heide høj 6, grav 5 (Behrens \& Schröter 1980, 68 ff., Abb 38). I sidstnævnte tilfælde er indgangen dog lidt usikker.

B-typen kendes tilsyneladende ikke uden for Danmark.

Type C1 kendes fra 4 tyske fund: Acker Meinecke grav 14 bygget af sten (Mathias 1974, 60 ff. Fig. 7b), Acker Mückenheim grav 1, orienteret SV-NØ med indgang mod NØ. Bygget af sten, Dölauer Heide høj 3, grav 1. I sidste tilfælde er gravkammeret bygget i sten, mens forrummet er bygget i træ. Herfra 

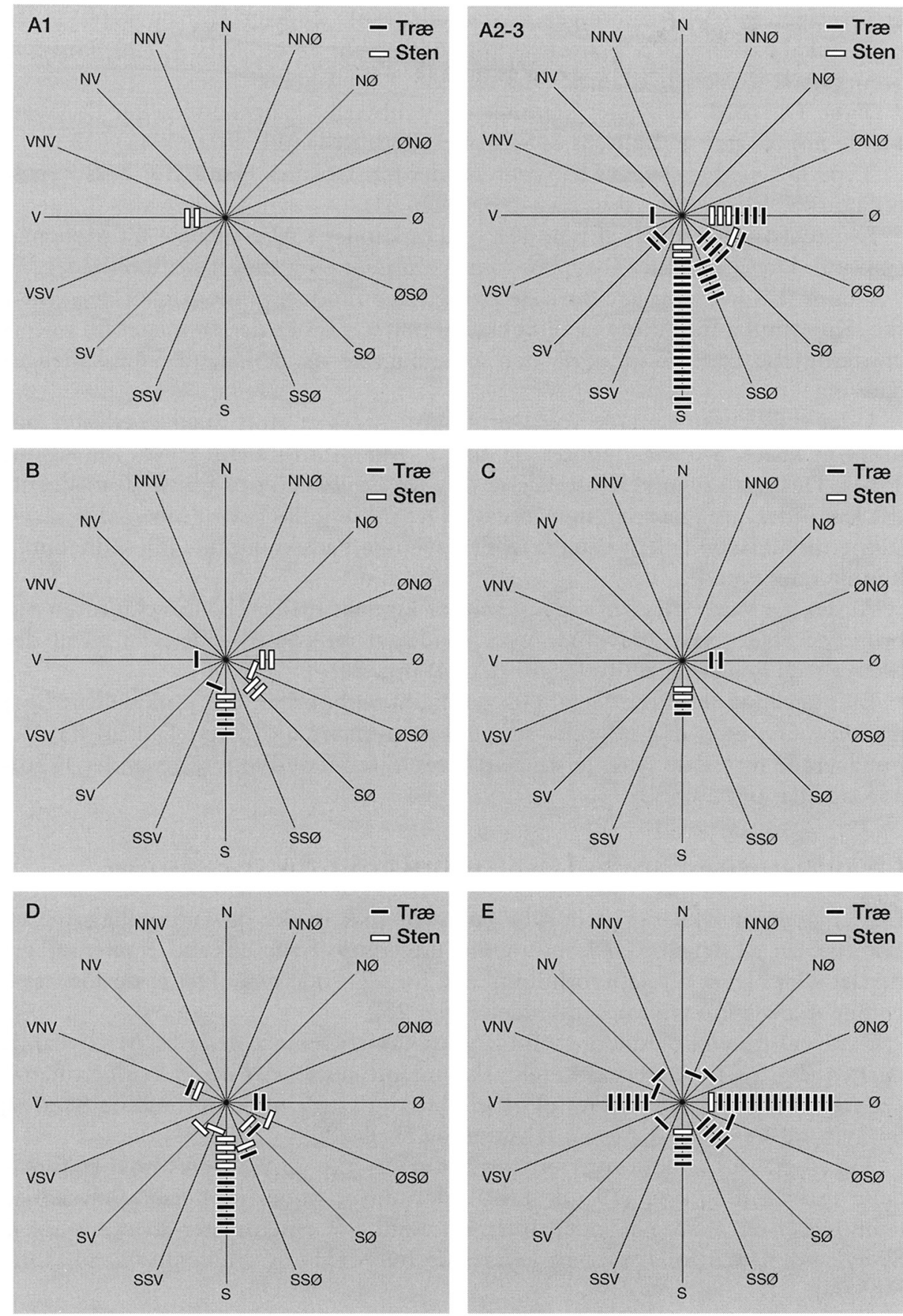

Fig. 23. Gravkisternes orientering. Dvs. indgangens orientering.

Entrance orientation of the wooden cists. 
er foretaget to C-14-dateringer med resultaterne: $2570 \pm 110$ og $2160 \pm 75$ e.Kr. (ukal.) (Behrens \& Schröter 1980, 64ff, Abb. 33 og Abb. 4, f-n), Grosser Steingrab II (Kretzsch 1955, 195ff, Abb. 9).

Type D1 med træbygget kammer og stenbygget gang kendes fra: Dölauer Heide høj 35 grav 1 (Behrens \& Schröter 1980, 84ff, Abb 48 a,c,h-n.) (32).

Type D2 med træbygget kammer kendes fra: Dölauer Heide høj 2 (Behrens \& Schröter 1980, 60ff, Abb. $30 \mathrm{~g}$-h og Abb. 31).

De stenbyggede kister af type D1 og D2 kendes i flere tilfælde fra Mellemtyskland. Dertil kommer E-typen, som er udbredt over meget store områder.

Det er vanskeligt at jævnføre de europæiske funds kronologi med den danske. Kun fundet fra Putten er tilstækkeligt belyst. Her er der en meget fin overensstemmelse både hvad angår den arkæologiske og den naturvidenskabelige datering.

I det sydsvenske område (og Bornholm) findes et stort antal gravkister og lukkede kister. I 1961 opgøres de til ca. 1400 (Strömberg 1952; Johansson 1961). Det store svenske materiale er dog ikke publiceret på en sådan måde, at det kan inddrages i nærværende arbejde. Det må dog slås fast, at ingen af gravkisterne tilsyneladende kan dateres til den svenske bådøksekultur. Fra senneolitikum kendes type E.

At der har været en eller anden form for kontakt mellem bådøksekulturen og brugerne af de jyske gravkister viser fundet af en svensk bådøkse $\mathrm{i}$ en af de træbyggede gravkister fra Keldgård (IA.14) (fig. 24).

En særstilling indtager de ca. 60 svenske Skogsbokister, der umiddelbart ligner type $\mathrm{C} 1$, men dog adskiller sig på flere punkter og i hvert fald ud fra det publicerede materiale synes at skulle dateres til senneolitikum (Forssander 1936, 156 og bl.a. fig. 29) (32).

\section{Gravkisternes oprindelse, udvikling og spredning}

Det er ovenfor lykkedes at opstille en typologisk række og sandsynliggøre, at kisterne har undergået en kontinuerlig udvikling, hvor enkelte elementer er udgået eller blevet tilføjet i forhold til den forudgående type. Det er derfor væsentligt at analysere typernes udbredelse (fig. 25).

Type A1 fra yngre undergravstid kendes kun i to eksemplarer fra Midtjylland og Fyn (fig. 25.1). Deres oprindelse skal uden tvivl søges i de små ringgrøftanlæg uden indgang, der dateres til både ældre og yngre undergravstid og kendes fra Syd- og Vestjylland, Slesvig-Holsten og Holland.

Typen A2-A3 kendes over et større område (fig. 25.2). Deres hovedudbredelse er i Himmerland (19 ud af 42). Derudover findes de i naboområderne (Vendsyssel og Viborg-Randersområdet), samt i fă eksemplarer på øerne og i Sydjylland. Uden for Danmark kendes de fra Nord- og Mellemtyskland samt Holland.

Type B kendes næsten kun fra Himmerland og tilgrænsende områder (fig. 25.3). Undtagelsen er én fra Sjælland. Typen er dog fătallig.

Type C har sin hovedudbredelse i Himmerland og Vendsyssel. Undtagelsen er et fund på Sydsjælland (fig. 25.4). Der er påfaldende mange fund fra Mellemtyskland. Typen er dog generelt fătallig. 

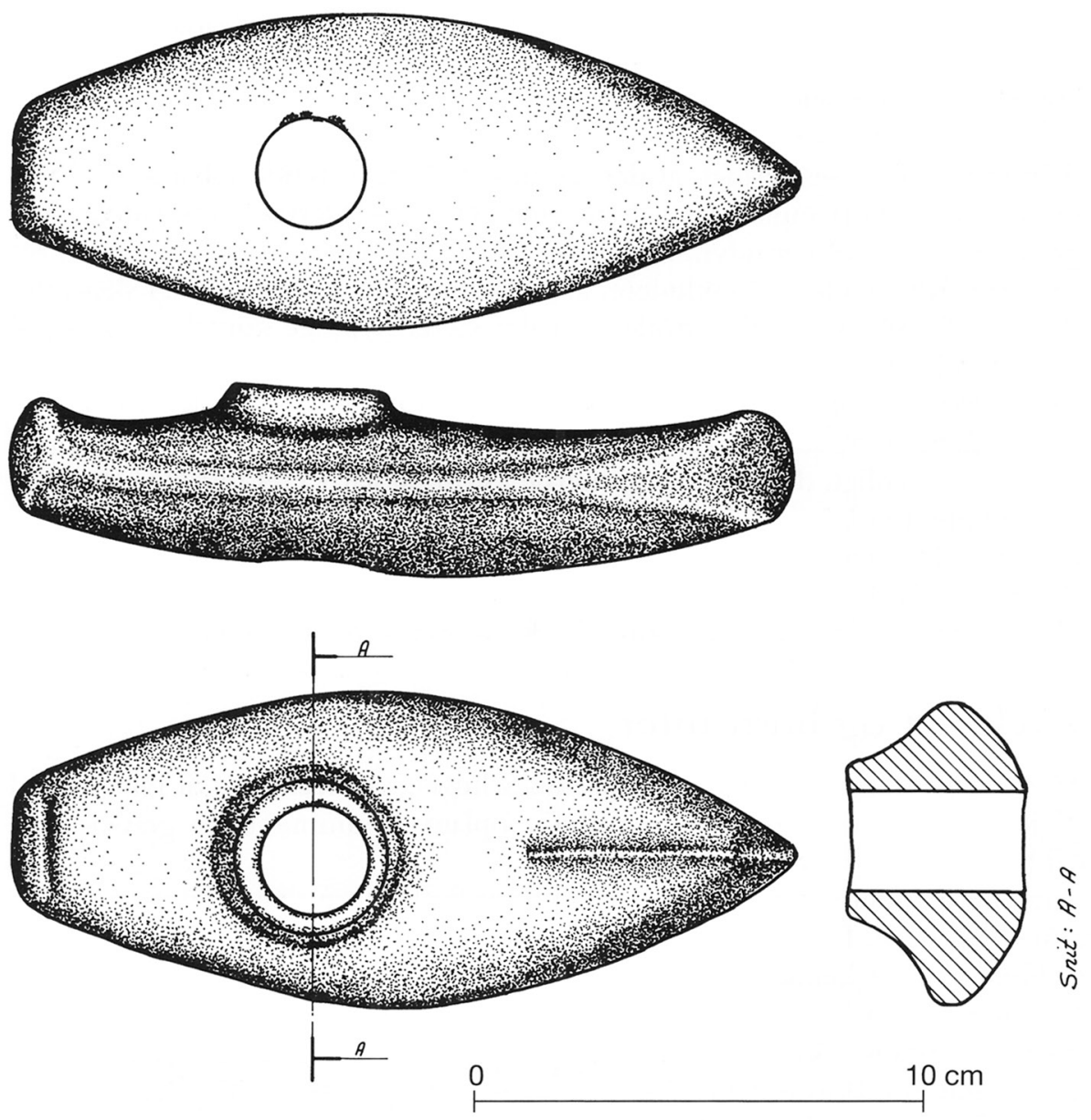

Fig. 24. Svensk bådøkse fra den træbyggede gravkiste i Keldgård høj 4 (IA.14).

Swedish boat-axe from the wooden cist in Keldgård barrow 4 (IA.14).

Type D har et kærneområde omkring Randers-Mariager og i Himmerland (fig. 25.5). Herudover kendes kun to fund fra henholdsvis Djursland og Vendsyssel. Typen kendes også fra Mellemtyskland.

Type E har sin hovedudbredelse på Sjælland med hovedvægten på Nord- og Nordvestsjælland samt i det vestlige Limfjordsområde med Mors som kærneområde (fig. 25.6). Et lille antal kendes fra Vendsyssel, Himmerland og de sydfynske øer. Desuden er typen vidt udbredt i Sverige og Tyskland.

Der tegner sig hermed et mønster fra gravkisternes første, yderst sporadiske optræden i den sydlige del af Danmark i yngre undergravstid (type A1) til en større udbredelse $\mathrm{i}$ begyndelsen af ældre bundgravstid, hvor Himmerland er et klart kerneområde (type A2-3). I slutningen af ældre bundgravstid og overgravstid (type B, C, D) findes gravkisterne næsten udelukkende i Himmerland og i Randersområdet samt i Mellemtyskland (type C og D) 
I senneolitikum har Himmerland udspillet sin rolle, og den vestlige Limfjordsegn og Nordsjælland bliver kærneområder i Danmark. Desuden bliver typen udbredt over store dele af Europa. Det eneste sted, hvor der er typologisk kontinuitet fra ældre undergravstid og til ind i senneolitikum er Himmerland.

Det er bemærkelsesværdigt, at der ses en næsten tilsvarende udvikling i Mellemtyskland. Dog mangler der i dette område tilsyneladende (den ældste) A1type og B-typen, som er udviklingsledet mellem A2-typerne og C-typerne. Det er derfor nærliggende at konkludere, at udviklingen af gravkisterne er sket i det østlige Limfjordsområde. I perioden har der været hyppige kontakter særlig til Mellemtyskland.

At udviklingen af gravkister (af type A2a) kan være indledt under inspiration fra visse jættestuer, som foreslået af Forssander (Forssander 1936, 115), forekommer sandsynligt, da netop jættestuerne i stort tal har været tilstede i landskabet og hyppigt er brugt til begravelser i perioden, hvor enkeltgravskulturen slår igennem i Himmerland. Dette understøttes yderligere af et fund af en træbygget jættestue fra Vroue, opført under enkeltgravskulturen (Jørgensen 1985). Her er det tydeligvis en $\mathrm{T}$-formet jættestue, der har været inspirationskilde.

\section{Gravkister og hustomter}

Det er en nærliggende tanke, at »de dødes huse«, gravkisterne, til en vis grad afspejler de levendes huse. Det er derfor oplagt at sammenligne gravkisterne med bopladsernes hustomter.

Fra yngre undergravstid kendes en hustomt fra Lustrup i Skarrild sogn (Rostholm 1982, 62ff). Der er tale om et cirkulært hus med en diameter på ca. $11 \mathrm{~m}$. Fra bundgravstid kendes endnu ikke hustomter, men fra overgravstid kendes hustomter fra Vorbasse (Hvass 1978), Skinderup, Viborg amt (Simonsen 1987, 140) og Djursland (Boas 1983). Sidstnævnte er muligvis senneolitisk eller meget sen overgravstid. Bortset fra netop dette klart rektangulære hus kan grundplanen på de øvrige ikke fastlægges i detaljer. Det ligger dog fast, at der er tale om rektangulære $\varnothing-\mathrm{V}$ orienterede huse. Andre hustomter fra overgravstid er endnu mere usikre med hensyn til deres grundplan, f.eks. Tofteparken (Hansen 1986a).

Fra senneolitikum kendes et større antal hustomter (Jensen 1973; Simonsen 1983, 1986, 1987) hvoraf de, der stammer fra samme geografiske områder som gravkisterne, skal inddrages her. De bedst bevarede af disse huse er rektangulære og har antagelig indgang i den ene gavl. Indgangen kan omfatte hele gavlbredden som ved Myrhøjhusene eller indgangen kan være begrænset til en del af gavlen som i huset fra Tastum. En anden detalje, som kendes fra huse både fra enkeltgravskulturen og senneolitikum er, at en større eller mindre del af gulvet er forsænket. Dette træk har muligvis en parallel i gravkisterne, hvor gulvet også kan være forsænket.

Fig. 25. Gravtypernes udbredelse. 1. Type A1. 2. Type A2-3. 3. Type B. 4. Type C. 5. Type D. 6. Type E. Distribution of the different types. 1. Type A1. 2. Type A2-3. 3. Type B. 4. Type C. 5. Type D. 6. Type E. 

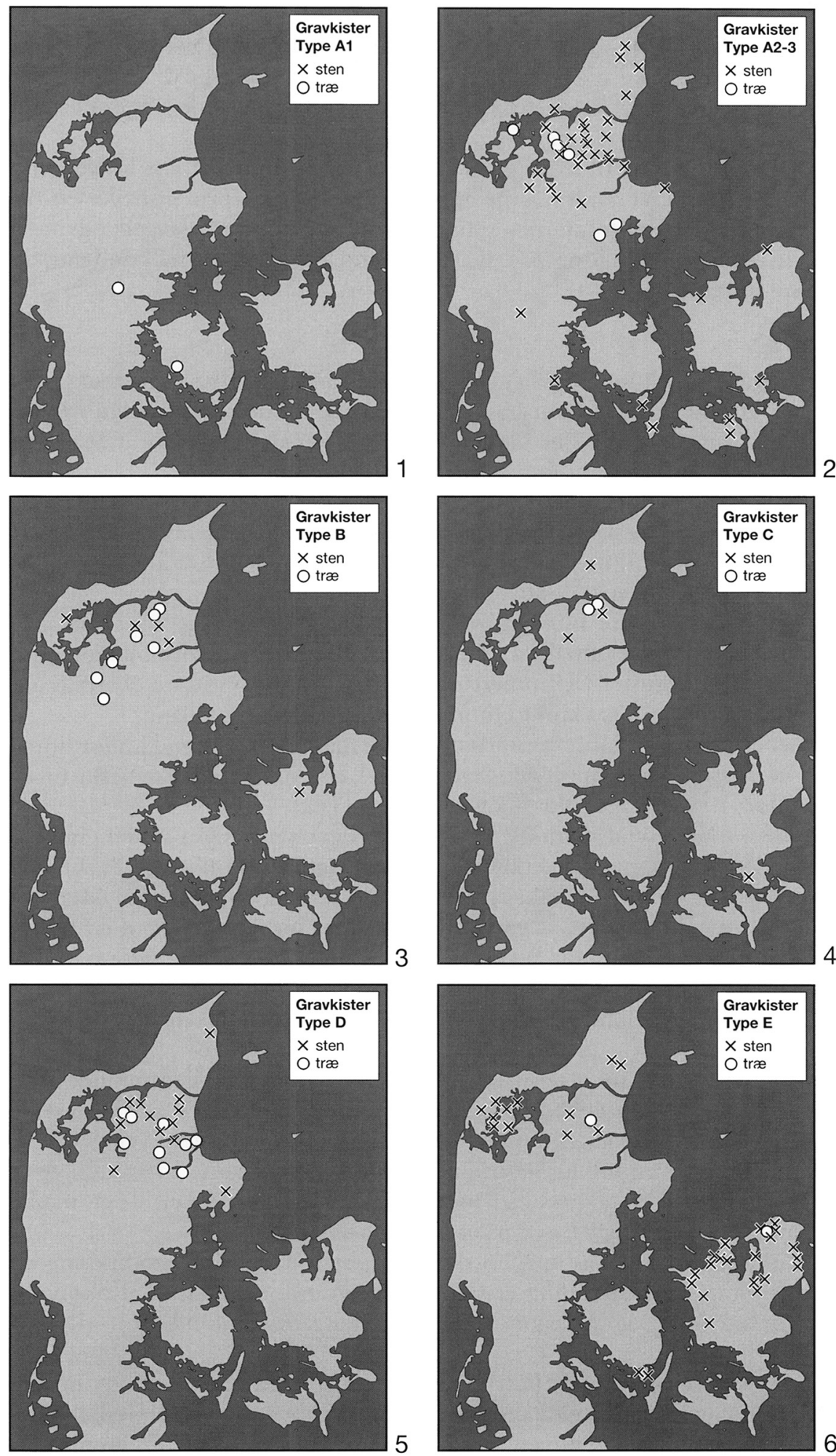
Hustomten fra Lustrup har en umiskendelig lighed med gravkisterne af type A1, og de senneolitiske huses lighed med gravkisterne af type E er også klar. Vedrørende overgravstid kan det på grund af de dårligt bevarede hustomter kun fastslås, at de i hvert fald har den rektangulære form tilfælles.

Det spinkle materiale til trods giver de kendte hustomter et vist holdepunkt for en hypotese om, at ændringerne af gravkisternes grundplan afspejler en tilsvarende ændring i hustomternes grundplan gennem enkeltgravstid og ind i begyndelsen af senneolitikum (33). Kun nye fund af hustomter fra bundgravstid kan afgøre spørgsmålet.

\section{Afslutning}

De træbyggede gravkister fremlægges og deres forskelligartede konstruktionsprincipper afdækkes. Der foretages en typologisk-kronologisk analyse, hvori også de stenbyggede gravkister inddrages. Herved er det lykkedes at fastlægge en typologi, der muliggør en findatering af gravkisterne.

Ved at sammenholde typernes kronologi og deres geografiske udbredelse viser det sig, at udviklingen af gravkisterne har taget sin begyndelse i området fra den sydlige del af Danmark til Holland i yngre undergravstid, hvor de er udviklet af "bikubegraven", de små ringgrøftanlæg.

I begyndelsen af ældre bundgravstid optræder de pære- og trapezformede gravkister over et større område i Nordeuropa. I sen del af ældre bundgravstid bygges der kun gravkister i Himmerland. I yngre bundgravstid og overgravstid findes gravkisterne stort set kun i Himmerland og i Mellemtyskland.

I senneolitikum A er Himmerlands rolle udspillet. Det vestlige Limfjordsområde og Nordsjælland er nu gravkisternes nye kærneområde i Danmark. Ligesom de findes i Sydsverige, Nord- og Mellemtyskland.

En dybere forståelse af denne udvikling vil kræve en analyse af alle gravformer, og ikke mindst tragtbægerkulturens megalitgrave, samt deres eventuelle genanvendelse gennem hele enkeltgravstiden og tidlig senneolitikum. Men det forekommer mig sandsynligt, at gravkisterne skal ses som et resultat af en relativ tæe befolkning med behov for fællesbegravelser. I perioder hvor ældre megalitgrave eller gravkister er blevet fyldt op i "mands minde", må der bygges nye anlæg. Først når de fyldte gravsteder er blevet "forældede" kan de ryddes og genbruges.

Tragtbægerkulturen anses normalt for at være et slægtsbaseret samfund, hvilket bl.a. kommer til udtryk ved opførelse af megalitgrave og den dertil hørende offerskik. Desuden fremgår det af de store langhuse, som er mere velegnede til store familiegrupper end til kernefamilier. Tragtbægerkulturens megalitgrave er formentlig bygget til enkeltpersoner med høj status eller en enkelt slægt, måske for at markere denne slægts hævd på et bestemt område.

Med enkeltgravskulturens opståen sker der tilsyneladende en atomisering og individualisering, der formentlig er udtryk for en omorganisering af økonomi og samfundsstruktur og reaktion mod den tidligere samfundsform (Damm 1989).

Gravkisternes opståen nogle få århundreder senere kan ses som en ny udvikling væk fra den tidlige enkeltgravskulturs samfundsform og hen i mod et samfund, hvor enhederne igen bliver større. Der er dog næppe tale om en tilbage- 
venden til det gamle slægtskabssamfund. Gravene bruges med korte mellemrum til successive begravelser, og spor efter ofringer forekommer ikke.

I øvrigt sker der, samtidig med det omfattende byggeri af gravkister i ældre bundgravstid, en kulturspredning, der kan spores $i$ form af af stridsøkser og keramik længere mod nord og øst i Danmark, og pollenundersøgelserne tyder på en bølge af skovrydninger. En nærmere forståelse af udviklingen kræver dog, at de øvrige gravformer og andre fundgrupper inddrages i en analyse. 


\section{Katalog over gravkister i Danmark}

\section{Katalog IA}

\section{Træbyggede gravkister}

Kataloget indeholder en oversigt over alle anlæg, der er forfatteren bekendt.

Oplysningerne består af katalognummer, lokalitet, sogn, stednr, fundår, orientering (indgangens orientering er mærket $\star$ ), type, datering (der anvendes flg. forkortelser EK = enkeltgravskultur/enkeltgravstid; SN = senneolitikum; $\mathrm{U}=$ undergravstid; $\mathrm{B}=$ bundgravstid; $\mathrm{O}$ $=$ overgravstid; $x=$ ældre; $y=$ yngre), ældste daterende genstand (økse- og keramiktyper efter Glob, dolktyper efter Lomborg), Museumsnummer, litteraturhenvisninger eller henvisninger til fremlæggelserne i artiklen.

Stridsøksernes datering: Til yngre Undergravstid $(y U)$ regnes $\mathrm{C}$ og D. Til ældre Bundgravstid $(æ B)$ regnes typerne $F, G, H$. Til yngre Bundgravstid (yB) regnes I og til overgravstid regnes $\mathrm{K}$ og L typerne. Dateringen af keramikken er i nogle tilfælde afvigende fra Glob. Se i øvrigt en kortfattet redegørelse hos Hansen 1986, 77ff. C-14 dateringerne opgives i kalibreret værdi \pm 1 standardafvigelse, efterfulgt af K-nr, C14-år og kalibreret datering.

IA.01: Drenghøj, Sejerslev s, Sb 89, (110409). 1983.

$0^{\star}-\mathrm{V}$. Type A2a. EKæB (ravring). C-14: 2870-2500 f.Kr.

(K-4269: $4100 \pm 85$ f. 1950.; kal.: 2620 f.kr.

(K-4269: $3990 \pm 60$ f. 1950; kal 2470 f.Kr.). MHM 506.

Fremlagt i artiklen.

IA.02: Sønder Tranders, Sønder Tranders s, Sb 29, (120113). 1976-7.

$\mathrm{S}^{\star}-\mathrm{N}$. Type C2. EKyB (økse I4a), C-14: 2580-2350 f.Kr.

(K-3472: $3980 \pm 85$ f. 1950; Kal. 2470 f.Kr.). ÅHM 691.

Fremlagt $\mathrm{i}$ artiklen.

IA.03: Kargård, Døstrup s, Sb 18, (120403). 1983.

SØ*-NV. Type B1a. EKæB (økse H), C-14: 2840-2470 f. Kr.

(K-4705; $4050 \pm$ 60f. 1950; Kal. 2570-2510 f. Kr. ÅHM 1374.

Johansen AUD 1986, s. 188.

IA.04: Rold, Rold s, (120407). 1947

S*-N. Type D2. SN (fliget pilespids). Reg. Ped. 1236.

Fremlagt i artiklen.

IA.05: Kovhøj, Store Arden s, (120410). 1960.

S*-N. Type E. SNA (dolk I). Reg. Ped. 1468.

Fremlagt i artiklen.

IA.06: Ø. Hornum, Svenstrup s, Sb 15, (120515). 1988.

$\mathrm{S}^{\star}-\mathrm{N}$. Type C1. EKyB (dolke I). ÅHM 2297. Birkedahl AUD 1988/186.

IA.07: Volstrup, Volstrup s, Sb 12,(120515). 1977.

$\mathrm{S}^{\star}-\mathrm{N}$. Type B2. EKæB (økse H1e), C-14: 2550-2280 f.Kr.

(K-4023: $3920 \pm 85$ f. 1950; Kal. 2460-2410 f.Kr). ÅHM 727x1-x10 og x49-x50).

Fremlagt i artiklen.

IA.08: Kragehøj, Volstrup s, Sb 13, (120515). 1977.

$\mathrm{S}^{\star}-\mathrm{N}$. Type B2. EKæB (økse H1d), C-14: 2480-2210 f.Kr.

(K-4022 $3910 \pm 85$ f. 1950; Kal 2450-2410. ÅHM 727x11-x48.

Fremlagt i artiklen.

IA.09: Flejsborg-Svenstrup II, Flejsborg s, Sb 50, (120804). 1987.

ØSØ^-VNV. Type D2, Udat. VMÅ 626. Hahn-Thomsen AUD 1987/197.

Danmarks længste udgravning 1987, 505. 
IA.10: Vesthimmerlands flyveplads høj 1, Ulstrup s (120812). 1980.

$\emptyset^{\star}-\mathrm{V}$. Type A3b. EKæB (ravring). VMA 47. (Hansen 1982; Hansen \& Rostholm 1993 afb s. 120). Fremlagt i artiklen.

IA.11: Vesthimmerlands flyveplads høj 2, Ulstrup s (120812). 1980.

SV^-NØ. Type D2. SNA (keramik). VMÅ 48.

Fremlagt i artiklen.

IA.12: Vesthimmerlands flyveplads høj 3, Ulstrup s, (120812). 1980

ØSØ夫-VNV. Type A2a. EKæB (økse F3). C-14: 2840-2460 f.Kr. (K3627: $4030 \pm 85$ f. 1950; Kal 2560-2500 samt C-14: 2610-2460 f. Kr. (K-3628: $4010 \pm 85$ f. 1950; kal. 2550-2490. VMA 49. (Hansen 1982). Fremlagt i artiklen.

IA.13: Kjeldgård høi 2, Aars s, Sb 145, (120814). 1978.

$\emptyset^{\star}-\mathrm{V}$. Type B2. Udat. VMA 8. Fremlagt i artiklen.

IA.14: Kjeldhøjgård høj 4, Aars s, Sb 81, (120814). 1978.

$\varnothing \varnothing_{-}$. Type A2a. EKæB (økse G1d),

C-14: 2590-2410 f.Kr.(K-3625: $4000 \pm 85$ f. 1950; Kal. 2490 f.Kr.

C-14: 2870-2500 f.Kr.(K-3626: $4100 \pm 85$ f. 1950; Kal. 2620 f.Kr. VMA 11. Hansen 1980, $91 \mathrm{ff}$.

IA.15: Fly, Fly s, (130104). 1989.

$\varnothing^{\star}-\mathrm{V}$. Type B1a. EKæB (økse H1). SMS 432A.

IA.16: Koldkur høj 14 grav E, Resen s, Sb 51, (130112). 1901.

SØ^-NV. Type B1a. Udat. NM A 19669-74. Glob 1944, 186; Jørgensen 1977, 154f, 221, 233. Fremlagt i artiklen.

IA.17: Hald, Orslevkloster s, Sb 45, (130117). 1970-71.

ØSØ夫-VNV. Type B1b. EKæB (ravring og økser H) C-14: 2550-2200 f.Kr. (K-1831: $3910 \pm$ 100 f. 1950; Kal. 2450-2410 f.Kr.

VSM 671C. Noe 1971; Malmros \& Tauber 1975, 87-88. Fremlagt i artiklen.

IA.18: Sundstrup 4, Lille Torup, Ulbjerg s, Sb 110, (130913). 1982.

VNV*_ØSØ. Type D1. Udat. VSM 955D. RAS (red) 1987, 296 nr 989.

IA.19: Kjeldagerhøj, Tånum s, Sb 3, (131209). 1923.

SSV^-NNØ. Type D1. EKO/SNA (keramik). NM A 32977-83. Glob 1944, 195 fog fig. 106. Fremlagt i artiklen.

IA.20: Demstrupvej, Dalbynedre s, (140401). 1986.

S*-N. Type D2. EKO (keramik). KHM 89/86.

Madsen \& Berg Nielsen 1987, 44ff; Schmidt AUD 1986/347 og AUD 1988/261.

IA.21: Toftelund I, Enslev s, Sb 15 (140403). 1982-83.

$\mathrm{S}^{\star}-\mathrm{N}$. Type D1. EKO (keramik). KHM 13/82. Fremlagt i artiklen.

IA.22: Glenstrup, "Kvindhøj«, Glenstrup s, (140604). 1960.

SSO ${ }^{\star}-N N V$. Type D1. EK. SYM 3064. Sterum 1974, 62ff. Fremlagt i artiklen.

IA.23: Langagergård, Essenbæk s, (141002). 1972.

S*-N. Type D2. EKO (keramik). KHM 120/72.

IA.24: Gunnerup II, Essenbæk s, Sb 24, (141002). 1990.

SO*-NV. Type D2. SNA (dolk I). KHM 1990/40. Olesen \& Stidsing AUD 1990/263.

IA.25: Lillering $X$, grav C, Framlev s, (150102). 1987.

$\mathrm{S}^{\star}-\mathrm{N}$. Type A2a. Udat. FHM 3252. Jensen, A.B. AUD 1987/318.

Der er en lille mulighed for, at graven i virkeligheden er stenbygget

IA.26: Asmusgård I, Elsted s, (150602). 1985.

$\mathrm{S} \star_{-}$N. Type A2a. Udat. FHM 3053. Andersen AUD 1985/272. 
IA.27: Damhalegard, Gadbjerg s, Sb 40, (170902). 1961-62.

V*_Ø. Type A1. EKyU (keramik). NM A 49681 ff. Thrane 1967, 27.

Fremlagt $\mathrm{i}$ artiklen.

IA.28: Sarup grav II, Hårby s, (080209). 1976.

$\mathrm{V}^{\star}-\varnothing$, Type A1. MNByU (keramik). FSM 50. Andersen 1978, 7.

IA.29: Ramløse Sokrog/Egedal, Ramløse s, (010109). 1990.

$\emptyset^{\star}-$ V. Type E. SN (keramik).

GIM 3356.2/3. Pedersen AUD 1990/11 og Pedersen 1993, 39 ff.

Når graven, trods mangel på direkte iagttagelser, må antages at have haft indgang, bygger det på, at der er dokumenteret 3 succesive gravlæggelser.

\section{Katalog I B}

\section{Træbyggede gravkister, typeubestemmelige}

IB.01: Fjordvang, Flade s. (100303), Morsø Nr. Herred, Hjørring Amt. Undersøgt i 1963 af Anders Willemoes for MHM (MHM x4).

Resterne af et træbygget kammer med støttesten, ca $4 \times 2 \mathrm{~m}$. Form og opdeling usikker. Den bageste, bevarede del, er rektangulær, hvorfor der er tale om type B, C, D eller E.

I graven fandtes 2 atypiske lerkar og 59 ravperler. Dateringen er antagelig sen enkeltgravskultur.

IB.02: Redsted høj 3, Redsted s, sb 98 (110512), Morsø Sønder herred og Thisted amt. Undersøgt af Palle Siemen for MHM (MHM 134).

Der fandtes et pæreformet anlæg omgivet af grøft og støttesten. Anlægget er orienteret $\varnothing-V$. Der fandtes to lag organisk materiale, der af udgraveren tolkes som sivmåtter. Mod øst, hvor der måske kan have været en indgang, er grøften gennembrudt af en grube, som iflg. udgraveren også er en del af anlægget. Adgangsforholdene er derfor uklare. Hvis den har haft indgang er der tale om type A2a.

Det formodede byggemateriale, sivmåtter, adskiller den også fra alle andre gravkister. I graven fandtes 4 ravperler. Dateringen må være enkeltgravskultur. Litt.: Siemen 1980.

IB.03: Alstrup grav 30, Alstrup s, sb 13 (120201). Undersøgt i 1976 af Erik Johansen. Resterne af et træbygget anlæg med bl.a. del af grøft. Der fandtes skeletrester af 3 personer. En stridsøkse af type $\mathrm{H}$ daterer anlæget til bundgravstid. Hverken form eller evt. indgang kan bestemmes. Litt.: Johansen 1977.

IB.04: Lundgård, Rostrup s. (120408). Undersøgt af Regnar Pedersen (Reg. Ped. 1421).

Et rektangulært N-S orienteret kammer. 3,8x2,4 m. I sydenden var gravens kanter usikker således, at der ikke kan registreres spor efter en eventuel indgang og graven kan udmærket have været et helt lukket kammer. Der fandtes 3 stridsøkser, 1 flintøkse og ravperler, repræesenterende 3 begravelser af personer, der har ligget øst-vest. En del forkullede planker lå direkte på gravbunden og representerer måske rester af rammegrave eller en anden opdeling af graven. Stridsøkserne er alle af Type I og dateres til EKyB. Litt.: Ebbesen, Acta 1983, 171, fundliste 2,13.

IB.05: Kjeldgård høj 1, Aars s. sb 146 (120814). Fig. 1.4. Undersøgt i 1978 af forfatteren for VMÅ (VMÅ 9). Anlægget består af en grøft med stolpe/plankespor. Anlægget er orienteret ØNØVSV. Den østlige ende var ødelagt af en recent forstyrrelse, og det er ikke muligt at afgøre om kammeret har været åbent eller lukket. Der fandtes ingen genstande i graven.

IB.06: Keldgård hoj 5, Aars s, NM sb 147. Fig. 1.7. Undersøgelsen er foretaget af forfatteren for Vesthimmerlands Museum i 1978.

Højen havde en diameter på ca 16 meter. Den lå på en naturlig højning og var stærkt nedpløjet. I højens østlige periferi fandtes en nord-syd-orienteret fyldskiftegrav med ravperler som eneste gravgods.

Gravkisten i højens centrum er træbygget, og der fandtes rester af et gravrum og et forrum. Gravrummet er rektangulært og måler 2,60x2,00 m, men kun delvis bevaret. Forrummet er kun bevaret $i$ en længde af $0,60 \mathrm{~m}$. 
Gravkisten er af type C1 eller C2. Gravkisten er orienteret nordvest-sydøst med indgang mod sydøst. Der blev ikke gjort fund i anlægget, hvorfor en nærmere datering ikke er mulig.

IB.07: Koldkur høj 11, Resen s, sb 58 (130112). Fig. 1.18. Undersøgt i 1901 af Rosenberg for NM (NM A19669-74). Den bageste afrundede del af et ødelagt træbygget kammer, bestående af en grøft. Anlægget har orienteringen NNV-SSØ. I gravrummet, der havde en bredde på 2,25 m og en bevaret længde på 2,5 m, fandtes skeletrester af 3-4 personer, 6 ravperler og en stridsøkse (type I3a) og dateres til EKyB. Litt.: Erik Jørgensen 1977, 153 og fig. 231.

IB.08: Bjerregård høj 4, Åle s, (160609). Fig. 1.18. Undersøgt i 1918 af G. Rosenberg for NM (NM A30039-56). Et U-formet grøftanlæg, delvis ødelagt af en sekundær enkeltgrav. Vurderet på baggrund af udgravningsfoto synes anlægget kun at være delvis undersøgt. Således kan der godt have været en smallere indgang og eventuelt et forrum. Den sekundære grav indeholdt flintøkse, to ravperler og en flintflække og kan derfor ikke dateres nærmere end enkeltgravskulturen $\mathrm{i}$ almindelighed. Litt.: Albrethsen \& Street-Jensen 1964, 12, note 18.

IB.09: Hudevad Vestergård, grav AR, Rolsted s, (080807). 1988.

Anlægget er bygget af såvel træ som sten. Formen er nærmest rektangulær. Det er usikkert om anlægget har åbning, og hvor den i givet fald har været. FSM 6972. Mikkelsen AUD 1988/130.

\section{Katalog II A}

\section{Stenbyggede gravkister, typebestemmelige}

Der anføres datering på grundlag af den ældste, daterbare genstand i graven.

IIA.001: Filholm, Tise s, Sb 71 (100112). 1938. Fredet.

$\varnothing \varnothing_{-}$. Type C1. SNB (dolk IIB).

NM A 38100-103. Lomborg 1973, 181, 185, 204.

IIA.002: Torsholm, Dronninglund s, (100203). 1902.

$\mathrm{S}^{\star}-\mathrm{N}$. Type A3b. SNA (dolk IA/B).

NM A 19809. Ebbesen 1983 nr 3.

IIA.003: Kjøskegard grav 1, Hallund s, (100204). 1929.

$S^{\star}-\mathrm{N}$. Type E. SN (keramik).

NM A 34455-60. Ebbesen 1983 nr 4, Fig. 9 og 13, 27.1-3.

IIA.004: Sneverholt, Hellum s, (100206). 1924.

$\mathrm{S}^{\star}-\mathrm{N}$. Type E. SNC (keramik).

NM A 32862. Ebbesen 1980.

IIA.005: Stendal, Understed s, Sb 112. (100212). 1907.

$\mathrm{SV}^{\star}$-NØ. Type A2b. Udat.

NM A 23317-18. Ebbesen 1983 nr 7.

IIA.006: Tottenborg, Flade s, Sb 62. (100303). 1912.

$\varnothing \star_{-} \mathrm{V}$. Type D1. Udat. Gangen danner en vinkel på 45 grader med kammeret.

NM A 26130, A2683-39mv. Müller 1911.

IIA.007: Birket I, Hørmested s, (100307). 1888.

SS ${ }^{\star}{ }^{\star}$-NNV. Type A2a, SNA (dolk IA). Undersøgt af Lønborg Friis. VHM 43/1968.

IIA.008: Norre Storgård, Mosbjerg s, Sb 116. (100309). 1979.

S*-N. Type A2a. EK/SNB (tværpil/dolke II) VHM 338/1979.

IIA.009: Svinehøj, Sønderhå s, Sb 8. (110112). 1903.

Ø夫-V. Type E. SNA (dolk IB). NM A 20948-55. Lomborg 1973, 201.

IIA.010: Thinghøj, Skjoldborg s, (110307). 1897.

ØNØ^-VSV. Type E. Udat. Udgravet af C. Neergaard for NM. 
IIA.011: Nr. Skjoldborg, Skjoldborg s, Sb 27. (110307).

$\mathrm{S}^{\star}-\mathrm{N}$. Type B1a. Udat. Besigtiget af Hans Kjær.

IIA.012: Bjergby, Bjergby s, (110402). 1966.

$\mathrm{V}^{\star} \star_{-} \varnothing$. Type E. SNA (dolk I). MHM 1090.

IIA.013: Sejerslev, Sejerslev s, Sb 47. (110409). 1924.

SV*-NØ. Type E. SNA (dolk Ix). NM A 32919-20.

IIA.014: Tusbjerg, Karby s, (110505). 1959.

Ø夫-V. Type E. SNA. (dolk Ix). MHM 1058x1-2.

IIA.015: Nyørndrup, Karby s, (110505). 1974.

$\mathrm{V}^{\star}$-Ø. Type E. SN (keramik). MHM x98.

IIA.016: Dalgård, Lødderup s, Sb 152. (110506). 1920.

NV*_SØ. Type E. SNA (dolk Ic). NM A 31166-74. Lomborg 1973, 201.

IIA.017: Lejrhøje, Kettrup s, Sb 59. (110704). 1961.

$\mathrm{S}^{\star}-\mathrm{N}$. Type A2a. Udat. NM A 49147-79. Ebbesen 1983 nr 10, fig. 35-37. (Ebbesen kalder den fejlagtig for Lerhøj).

IIA.018: Lundby, Gunderup s, (120104). 1899.

$\mathrm{S}^{\star}-\mathrm{N}$. Type D2. EKO (ravperler). NM A 17264-68. Ebbesen $1983 \mathrm{nr} 11$.

IIA.019: Torderup, Gunderup s, (120104). 1904.

$\mathrm{S}^{\star}-\mathrm{N}$. Type C1. EKO (økse L4a). NM A 22239-42. Ebbesen $1983 \mathrm{nr} 12$.

IIA.020: Ll. Binderup II, Binderup s, (120202). 1925.

S*-N. Type C2. SNC (dolk VA). VMÅ 300/A321. Lomborg 1973, 204 (EK); Ebbesen 1983 nr 15.

IIA.021: Romdrup, Romdrup s, (120110). 1895.

SS $\star^{\star}-N N V$. Type A2a. SNC (dolk VB). NM C 8005-11. Ebbesen 1983 nr 13.

IIA.022: Bjerrevang, Farsø s, (120204). 1939.

$\mathrm{S}^{\star}-\mathrm{N}$. Type D2. EKO (økse K7). NM A 38177-81; VMÅ 631.

Fundet er overdraget Th. Mathiassen, NM i 1939. Graven er beskrevet detaljeret af finderen for forfatteren i 1989.

IIA.023: Røjdrup, Stenild s, Sb. 3, (120211). 1955.

$\mathrm{S}^{\star}-\mathrm{N}$. Type A2b. EKyB (I3c). Reg. Ped. 1420. Ebbesen 1983 nr 17. Stridsøksen er ikke type $\mathrm{H} 2$, som anført af Ebbesen.

IIA.024: Lille Ulvedal, Blenstrup s, Sb 26 (120301). 1985.

S*-N. Type D2. EKO (keramik). ÅHM 1025. Johansen AUD 1986/238.

IIA.025: Korup Skovhuse, Solbjerg s, (120311). 1948.

$\mathrm{S}^{\star}-\mathrm{N}$. Type A2a. Udat. ÅHM 160.

IIA.026: Visborg høj, Astrup s, Sb 39, (120402). 1913.

SØ`-NV. Type D2. EKO (keramik). NM A 27388-91. Ebbesen 1983 nr 21 og fig. 11 og 19.

IIA.027: Tisted Brudehøj, Astrup s, (120402). 1887-88

$S^{\star}-N$. Type D1. Udat. Fredet. Oplysninger fra sognebeskrivelsen og M. Iversen 1972.

IIA.028: Harehøjgård, Vrå Mark, Rostrup s, Sb 14, (120408). 1927.

S*-N. Type E. SNB (dolk IIB). NM A 33629. Lomborg 1973, 204.

IIA.029: Loddenhøj, Rostrup s, Sb 112 (120408). 1956.

$\mathrm{S}^{\star}-\mathrm{N}$. Type A2a. SNA (dolke IB, IC, Ix). ÅHM 3. Ebbesen $1983 \mathrm{nr} 22$ og fig. 4, 26, 29, 32-34.

IIA.030: Blegødal, Rostrup s, (120408). 1970.

$S^{\star}-N$. Type B1b. EKO (keramik). FHM 1687. Undersøgelse ved P. Kjærum. 
IIA.031: Raveknold, Vebbestrup s, (120412). 1949.

$\mathrm{S}^{\star}-$ N. Type D1. EKO (keramik). Reg. Ped. 1311. Ebbesen 1983 nr 26.

IIA.032: Merritsholt høj 1, Vive s, Sb 115 (120414). 1933.

S*-N. Type A2a. EKO (keramik L1, økse K7). NM A36455-58 Ebbesen 1983 nr 29 og fig. 38.1-2.

IIA.033: Svalhøjgard, Vive s, Sb 115 (120414). 1933.

$\mathrm{S}^{\star}-\mathrm{N}$. Type A3a. SNA (dolk IB). NM A 36462-71. Ebbesen $1983 \mathrm{nr} 30$ og fig. 23.

IIA.034: Gravlev Hede, Gravlev s, Sb 25 (120505). 1906.

S*-N. Type B2. EKO (keramik I5). NM A 22942-63. Ebbesen 1983 nr 32.

IIA.035: Flø, Gravlev s, Sb 26 (120505). 1925.

$\mathrm{S}^{\star}-\mathrm{N}$. Type A2a. SNA (dolk Ix). NM A 32933-35. Ebbesen 1983 nr 33.

IIA.036: Gravlev Mark, Gravlev s, Sb 20 (120505). 1934.

SØ^-NV. Type A2b. SNA (dolk I A/B og lerkar B3). NM A 36091-117. Ebbesen 1983 nr 31 og fig. 12 .

IIA.037: Sønderholm, Sønderholm s. Sb 74=28a (120511). 1932.

SØ^-NV. Type A2b. EKO/SNA (keramik). NM A 35847-79. Ebbesen 1983 nr 36 og fig. 6, 20 (han henviser dog fejlagtigt til sit eget kat. nr 26 og fig. 21).

IIA.038: Rodsted Mark, Sønderup s. (120512). 1897.

VNV*_ØSØ. Type D2. EKO(SNA?) (keramik). NM A 16512. Glob 1944, 281.

IIA.039: Klingerhøj, Ø. Hornum s, (120515). 1907.

S*-N. Type A2a. EKyB (økse I4c) ÅHM 352. Ebbesen 1983 nr 42 og fig. 18.

IIA.040: Kirkebjerghøjen, Malle s, Sb 29, (120707). 1971.

$S^{\star}$-N. Type A2a. EKyB (økse I). VMÅ 430. FHM 1615. Vellev 1971 og 1975.

IIA.041: Store Ajstrup I, Store Ajstrup s, Sb 13, (120713). 1900.

S*-N. Type D2. SNC (dolk VA). NM A 6289-91. Ebbesen 1983 nr 43 (her henvises fejlagtigt til NM A 6389-91 og sb 17).

IIA.042: Store Ajstrup II, Store Ajstrup s, Sb 49, (120713). 1895.

$\mathrm{S}^{\star}-\mathrm{N}$. Type D2. Udat. NM A 13400-423. Undersøgt af Sarauw.

IIA.043: Blare, Blære s, Sb 53, (120801). 1981. Fredet.

SSV^-NNØ. Type B1b. SNA (dolke I). VMÅ 79, ÅHM 1341. Fabech 1986.

IIA.044: Onsildhøjgård/Ll. Rørbak, Ravnkilde s, Sb 38 (120810). 1943.

S*-N. Type A2c. EKO/SNA (keramik). Reg. Ped. 897-8. Ebbesen 1983 nr 44.

IIA.045: Lynnerup grav A1, Skivum s, Sb 41 (120811). 1982.

SSØ^-NNV. Type A2b. EKæB (økse G). ÅHM 1411. VMÅ 170. Undersøgt af E. Johansen, $\AA ̊ 丿$ og E. Hasselgren, VMÅ.

IIA.046: Lynnerup grav A3, Skivum s, Sb 41 (120811). 1982.

$S^{\star}-N$. Type E. Udat. ÅHM 1411. VMÅ 170. Undersøgt af E. Johansen, ÅHM og E. Hasselgren, VMA.

IIA.047: Pugholm, Aars s, Sb 86. (120814). 1890.

S*-N. Type A2b. SNA (dolk I). FSM 517-26. VMÅ 1498. Undersøgt af Pastor Brummer, Aars.

IIA.048: Vester Oustrup, Aars s, Sb 21. (120814) 1936.

S*-N. Type A2b. EKO (keramik). VMÅ325/A569. Ebbesen 1983 nr 46.

IIA.049: Kobberup, Kobberup s, (130107). 1966.

SØ^-NV. Type A2b. EKæB (økser G/H og I), C-14: Hassel fra bundlag 2560-2150 f.Kr. (K1284: $3900 \pm 120$ f. 1950, kal. 2450-2370 f.Kr.); Eg fra indgang 2880-2490 f.Kr.(K-1367: 4110£100 f.Kr. kal. 2840-2620). FHM 1502. Kjærum 1967; Malmros \& Tauber 1975. 
IIA.050: Mønsted, Mønsted s, Sb 3, (130110). 1897.

S*-N. Type D1. EKO (keramik). NM A 15904-05. Ebbesen 1983 nr 47.

IIA.051: Bøstrup, Ørslevkloster s, Sb 131a, (130117). 1898.

S*-N. Type A2b. EKO (keramik). NM A 17152-59. Ebbesen 1983 nr 48.

IIA.052: Helstrupgård, Helstrup s, (130704). 1915. Fredet.

SSØ^-NNV.Type A2a. EKO (økse K6). NM A 28431-46. Ebbesen 1983 nr 51, fig. 8,16,17.

IIA.053: Vestergård, Fiskbæk s, Sb 44, (130805). 1900.

$\mathrm{S}^{\star}-\mathrm{N}$. Type A2a. SNC (keramik). NM A 18833. Ebbesen 1982 note 14, fig. 1. (anlægget betragtes ikke som en gravkiste af Ebbesen).

IIA.054: Viborg Hedeplantage, Viborg s, Sb 1, (130815). 1939.

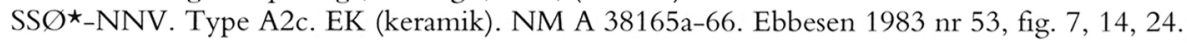

IIA.055: Højslev Mølle, Simested s, (130910). 1900.

S*-N. Type E. SNA (dolke I) NM A 18407-08. Lomborg 1973, 205.

IIA.056: Gjerrild, Gjerrild s, Sb 9, (140106). 1956.

$\mathrm{S}^{\star}$-N. Type A2a. EKO (keramik). NM A 44572-78. Kisten er noget forstyrret. Typen er bestemt ud fra gravbundens form, som dog er lidt usikker. Vebæk 1957, 75ff; Ebbesen 1983 nr 62, fig. 30 $\operatorname{og} 31$.

IIA.057: Bjørnsholm, Tirstrup s, Sb 32, (140212). 1935.

$\varnothing^{\star}-V$. Type D1. SNC (dolk IV D). NM A 37683-87. Lomborg 1973, 187 (SN). (Kammeret er dog atypisk, idet kammer og gang danner en vinkel på ca $45^{\circ}$ med hinanden, således at gangen vender mod $\mathrm{S} \varnothing)$.

IIA.058: Udbyovre, Udbynedre s, (140409). 1899.

S*-N. Type A2b. SNA (dolke IB,Ix). NM A 17557-60, A19848-49. Ebbesen 1983 nr 63.

IIA.059: Katbjerg, Mariager s, Sb 176, (140705). 1890.

SSØ^-NNV. Type D1. EKO (økse L3a). NM A 9731-42. Ebbesen 1983 nr 64.

IIA.060: Vittrup, Lindknud s, Sb 186, (190305). 1910.

V*_Ø. Type A3a. EKyB (økse I). NM A 26274-77.

IIA.061: Ábak, Løjt s, (220203). 1873.

$\varnothing^{\star}-\mathrm{V}$. Type A3a. EKyB (økse I3c). NM A 1536.

IIA.062: Bakkebjerg, Blidstrup s, Sb 46 (010112). 1921.

$\varnothing \varnothing^{\star}-V$. Type E. Udat. NM B 11468-74.

IIA.063: Udsholt, Blidstrup s, (010112). 1910.

Ø^-V. Type E. SNB (dolk IIB). NM A 26285-86. Kjær 1910, 176-78, 204; Lomborg 1973, 201.

IIA.064: Ramløse, Ramløse s, (010109). 1887.

Ø^-V. Type E. SNB (dolk IIA). NM A 6918-19. Kjær 1910, 204; Lomborg 1973, 201.

IIA.065: Hanebjerg grav BB, Vejlby s, Sb 42, (010113). 1945.

$\varnothing \varnothing^{\star}$ V. Type E. SNB (dolk IIB). NM A44029-48.

IIA.066: Hanebjerg grav T, Vejlby s, Sb 42, (010113). 1945.

$\varnothing \star-V$. Type A2b. Udat. NM A 44029-48.

IIA.067: Esromgård, Gerlev s, (010203). 1902.

Ø^-V. Type E. SNC (dolk IVC). NM A 19822, B 7698. Kjær 1910, 178-79; Lomborg 1973, 201.

IIA.068: Smidstrupgård, Hørsholm s, Sb 52 (010410). 1867.

VNV^_ØSØ. Type E. SN B (dolk IIA). NM A 282-84. Kjær 1910, 204; Lomborg 1973, 180, 201.

IIA.069: Skjeldhøj, Kongens Lyngby s, (Lyngby-Tårbæk), Sb 10 (020307). 1869.

Ø夫-V. Type E. Udat. NM beretning. Knudsen 1982, $69 f$. 
IIA.070: Kohaven, Søllerød s, (020310). 1908.

$\varnothing S \varnothing{ }^{\star}-V N V$. Type E. Udat. Fredet. NM j.nr 203/08.

IIA.071: St. Valbyvej høj I, Himmelev s, (020405). 1986-87.

$\mathrm{V}^{\star}$-Ø.. Type E. SNA. ROM 659/86. Schiellerup 1991, $22 \mathrm{f}$

IIA.072: St. Valbyvej høj II, Himmelev s, (020405). 1986-87.

$V^{\star}$-Ø. Type E. SN. ROM 659/86. Schiellerup 1991, 35ff.

IIA.073: Gerdrup, Kirkerup s, (020408). 1963.

S $\varnothing^{\star}$-NV. Type E. SNC (dolk IV/V). NM A 49230-37. Liversage 1964, 32; Lomborg 1973, 201 (SN).

IIA.074: Uggerløse Grasmark, Rørby s, Sb 52 (030104). 1928.

SO^-NV. Type E. SNB (dolk IIIB). NM A 33819-20. Liversage 1964 note 53; Lomborg 1973.

IIA.075: Frihedslund, Søby s, Sb 11a, (030214). 1893.

$\varnothing^{\star}-V$. Type E. SNB (dolk IIB). NM A 12316-19. Müller 1902, 147-47; Kjær 1910, 205; Lomborg 1973 .

IIA.076: Åstofte, Asnæs s, Sb 71, (030401). 1919.

$\varnothing^{\star}-\mathrm{V}$. Type E. Udat. NM A 30814.

IIA.077: Varsbakke grav B, Fårevejle s, Sb 49, (030403). 1938.

NØ`_SV. Type E. SN (skifferhænger). NM A 38377-86.

IIA.078: Varsbakke grav F, Fårevejle s, Sb 49, (030403). 1938.

SØ夫-NV. Type E. SN (lerkar). NM A 38377-86. Lomborg 1973, 166.

IIA.079: Grevinge, Grevinge s, Sb 28, (030404). 1933.

$\mathrm{V}^{\star}$-Ø. Type E. SN (lerkar). NM A 35810-12. Liversage 1964 note 36.

IIA.080: Paradishøj Lumsås, Højby s, Sb 7, (030405). 1918.

Ø夫-V. Type E. SNC (dolk IVD). NM A 30058; Lomborg 1973, 201.

IIA.081: Muldhøj/Eskebjerg, Bregninge s, Sb 90 (030603). 1911.

$\varnothing^{\star}-$ V. Type E. SNB (dolk IIIC). NM A 26658-59. Lomborg 1973, 201.

IIA.082: Olstrupgård, Bregninge (030603). 1919.

$\varnothing^{\star}$-V. Type A2a. SNB (dolk IIIA). NM A 30303-04. Lomborg 1973, 182,184; Becker 1974, 95 note 8. Andersen, H.A. 1986, 72 fig. 8.5.

IIA.083: Drusebjerg, Kundby s, Sb 10, (030707). 1929.

$\varnothing^{\star}$-V. Type E. SNC (dolk VA). Holbæk 3091. Lomborg 1973, 201; Liversage 1964 note 42 kalder fejlagtig sognet for Kyndby.

IIA.084: Tuse, Tuse s, Sb 20, (030713). 1954.

$\mathrm{V}^{\star}$-Ø. Type B1a. SNB (dolk IIB). NM A 45210-11. Indgangen danner en vinkel på 45 grader med kammeret. Lomborg 1973, 201 (SN); Liversage 1964 note 45.

IIA.085: Senderup, Sønderup s, (040318). 1895.

$\varnothing^{\star}$-V. Type E. SN (bennål). NM A 14722. Müller 1902, 146-47; Kjær 1910, 205.

IIA.086: Smidstrup Hovgård, Skibinge s, Sb 50 (050210). 1906, 1940.

SØ夫-NV. Type A2a. MNæB (keramik C2). NM A 26693, A 38590-91. Becker 1940, 33; Glob 1944, 193; Lomborg 1973, 204; Becker 1974, 93ff.

IIA.087: Snertinge, Sværdborg s, (050409). 1897.

$\varnothing^{\star}$-V. Type C1. SNC (dolk VA, IIA/VIA). NM A 16522-24. Müller 1902, 148-49; Liversage 1964 note 48; Lomborg 1973, 201 (SN).

IIA.088: Musse, Musse s,(070612).

$\varnothing^{\star}$-V. Type A2a. EKæB (økse H2b). NM A 25351-53. Becker 1936, 154; Glob 1944, 72; Glob 1952, 418, 428; Becker 1974; Becker 1974, 93. 
IIA.089: Orebygård, Tårs s (070620). 1877.

SV^-NØ. Type A2a. EKB (keramik C1, D7, E2). NM A 36585-600, Montelius 1900, 118; Becker 1936, 150, 152; Glob 1944, 74, 193; Becker 1950, 260.

IIA.090: Herslev, Lindelse s, Sb 65, (090301). 1924.

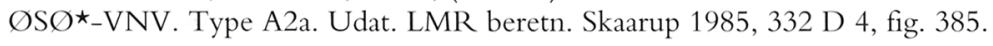

IIA.091: Bjerreby, Bjerreby s (090501). 1950.

S*-N. Type A2a. EKO (økse K1b). Becker 1974, 89-95; Skaarup 1985, 339, nr D33.

IIA.092: Lundby, Landet s, Sb 22 (090507). 1974.

SØ^-NV. Type E. SN. LMR 8435. Skaarup 1985, 339f. D34 fig. 394.

IIA.093: Bakkehave Klint, Landet s, Sb 23 (090507). 1975.

Ø夫-V. Type E. Udat. FSM 1407. Skaarup 1985, 340f. D38.

\section{Katalog IIB}

Katalog over gravkister, der ikke kan typebestemmes.

Når de ikke kan bestemmes, skyldes det ofte mangelfulde oplysninger eller dårlige bevarings forhold. Men der tale om kister, der med overvejende sandsynlighed har indgang og ofte kan dateres til EK eller SN.

IIB.01: Filholm I, Tise s, (100112).

SNA. VHM 3156-67. Lomborg 1973, 205 (X).

IIB.02: Sondergård grav II, Tolstrup s, Sb 117, (100113). 1960.

MNB. VHM 1960/182-260. Lomborg 1973, 189 (usikker gravtype); Ebbesen 1983 nr 1. Ebbesens typebestemmelse af dolken er fejlagtig.

IIB.03: Linderup, Tolstrup s, (100113). 1856.

S*-N. SNA. NM 15801-06. Lomborg 1973, 173 (usikker gravtype); Ebbesen 1983 nr 1.

IIB.04: Tommerby, Tolstrup s, (101113). 1878

ØSØ^_VNV. MNBB. NM A 3160-71. Glob 1944, 281; ej Ebbesen 1983.

IIB.05: Rishøj, Hallund s, (100204). 1929.

S*-N. MNB/SNA. NM A 34461-62. Lomborg 1973, 203 (M); Ebbesen 1983 nr 5.

IIB.06: Hallundbjerg, Hallund s, Sb 58, (100204). 1908.

S*-N. SNA. NM A 24267. Lomborg 1973, 204 (EK). Ebbesen 1983 nr 6.

IIB.07: Gundestruphus, Hørby s, Sb 187, (100207). 1907.

S*-N. SNA. NM A 23243-44. Lomborg 1973, 204 (EK); ej Ebbesen 1983.

IIB.08: Birket II, Hørmested s, Sb 64 (100307). 1890.

»Kiste omtrent som ..(IIA.07)«. VHM 44/1968 (2717-18).

IIB.09: Nørre Skjoldborg, Skjoldborg s, Sb 27, (110307). 1913.

$S^{\star}-$ N. Kilde: sognebeskrivelsen.

IIB. 10: Hingelbjerg, Kollerup s, (110706). 1897.

SSØ^_NNV. Udat. NMA 16641-51. Glob 1944, 281 (gravkiste).

IIB.11: En af »Trehøjene«, Aggersborg s, Sb 11 (100701). 1878.

$\mathrm{S}^{\star}-$ N. Udat. Ebbesen 1983 nr 8.

IIB. 12: Orslev, Kettrup s, Sb 45 (110704). 1943.

$\mathrm{S}^{\star}-\mathrm{N}$. Måske type A3. Ebbesen 1983 nr 9.

IIB. 13: Alstrup, Alstrup s, Sb 36/37 (120201). 1868.

S*-N. SNA. NM A555-58. Ebbbesen 1983 nr 14. 
IIB. 14: Ll. Binderup, Binderup s, Sb 12, (120202). SN, 1985.

SV*-NØ. Gravkistetomt. ÅHM 1720. Johansen AUD 1985/164.

IIB. 15: Nagelhøje, Hole, Lovns s, Sb 1, (120209).

S*-N. SN. Dreyers Samling. Ebbesen 1983 nr 16.

IIB. 16: Galgehøj, Blenstrup s, (120301). 1909

S*-N. SNA. NM A 25346-49. Lomborg 1973, 204 (EK); Ebbesen 1983 nr 18.

IIB. 17: Jagersborg Skov, Fræer s, Sb 37, (120303). 1886.

$\mathrm{S}^{\star}-\mathrm{N}$. Udat. Kilde: sognebeskr.

IIB. 18: Rebild, Skørping s, Sb 174, (120310). 1929.

S*-N. Udat. Ebbesen 1983 nr 19.

IIB.19: Solbjerg, Solbjerg s, Sb 61, (120311). 1886.

SO^-NV. SN Ebbesen 1983 nr 20.

IIB.20: Katrinaholm, Astrup s, (120402). 1938.

$\div$ orient. SNA. ÅHM 1173/A607-11. Marseen 1938 (Himm og kær). Lomborg 1973, 204 (EK).

IIB.21: Kovring høj, Rold s, (120407). 1960.

SSV*_NNØ. MNB/SN. Reg. Ped. 1472.

IIB.22: Vrå, Rostrup s, (120408). 1958.

$\mathrm{S}^{\star}-$ N. MNB. ÄHM 27/A751. Ebbesen 1983 nr 23.

IIB.23: Store Arden, St. Arden s, (120410). 1960.

S*-N. SNC. Reg. Ped. 1467. Ebbesen 1983 nr 24.

IIB. 24: Hermans Høj, Nedre Karls, Valsgård/Oue s, Sb 53 (120406/11). Fredet. 1887.

SO^-NV. MNBO. ÅHM 1966a-i. Genstandene er ikke gået tabt som Ebbesen hævder. Glob 1944, 281 (usik. gravkiste EK/SN); Lomborg 1973, 205 (EK); Ebbesen 1983 nr 25.

IIB.25: Vive I, Vive s, Sb 71 (120414). 1887.

S*-N. SNA. NM A 8100-06. Ebbesen 1983 nr 27.

IIB. 26: Vive II, Vive s, Sb 81 (120414). 1887.

$\mathrm{S}^{\star}$-N. Udat. Ebbesen 1983 nr 28.

IIB.27: Hjortsholm, Albæk, Suldrup s, Sb 4, (120509). 1887.

SSO^-NNV. SNA. NM A 387569a-d. Lomborg 1973, 204 (EK); Ebbesen 1983 nr 34.

IIB.28: Svenstrup Vestergård, Svenstrup s, (120510). 1894.

$\mathrm{S}^{\star}$-N. MNB. AHM 2366. Glob 1944,281 (gravkiste, bundgravstid); Ebbesen 1983 nr 35.

IIB.29: Sønderholm, Sønderholm s, Sb 75, (120511). Fredet 1953.

$\mathrm{S}^{\star}-\mathrm{N}$. Ebbesen 1983 nr 37.

IIB.30: Tostrup, Sønderholm s, Sb 100, (120511). 1967.

S ${ }^{\star}$-NV. MNBO. ÅHM 105/A942-44. Ebbesen 1983 nr 38.

IIB.31: Sønderup, Sønderup s, Sb 6, (120512). 1898.

SSØ^-NNV. MNBO. NM A 17109-25. Glob 1944,281 (gravkiste); Lomborg 1973, 205 (EK); Ebbesen 1983 nr 40.

IIB.32: Rodstrupgårde, Vokslev s, Sb 115 (120514). 1926.

S*-N. SNC. NM A 32859-61. Lomborg 1973, 205 (EK); Ebbesen 1983 nr 41.

IIB.33: Vokslev Mark, Vokslev s, (120514).

SNA. ÅHM 1743a-l. Lomborg 1973, 205(X).

IIB.33a: Korsdalsgård, Vindblæs s, (120715). 1981.

S-N. MNBB/O. ӒHM 1268.

IIB.34: Kongshøj, Onsildhøjgård, Ravnkilde s, Sb 38, (120810). 1943.

$\mathrm{S}^{\star}$-N. SNC. NM A 32859-61. Lomborg 1973, 205 (EK); Ebbesen 1983 nr 41. 
IIB.35: Tandrupgård I, Aars s, sb 32. (120814). 1986.

$\mathrm{S}^{\star}$-N. Ubestem. Type . Udat. VMÅ 281. Jørgensen AUD 1986/263

Tomten af en gravkiste.

IIB.36: Tandrupgaird II, Aars s, sb 31. (120814). 1986.

S*-N. Ubestem. SN. VMA 282. Jørgensen AUD 1986/264.

Tomten af en gravkiste.

IIB.37: Svenstrup Hede II, Aars s, Sb 2, (120814). 1990.

$\mathrm{SSV}^{\star}-\mathrm{NN} \oslash$. Udat. Tomten af en gravkiste. VMA 1342. Jørgensen og Klingenberg AUD 1990/202.

IIB.38: Daubjerg, Daubjerg s, Sb 5, (130101). 1899.

S*-N. MNBO. NM A 17715-20. Lomborg 1973, 205 (EK); ej Ebbesen 1983.

IIB.39: Hald, Ørslevkloster s, Sb 40, (130117). 1890.

NØ^_SV. MNBO. NM A 9794-95. Glob 1944, 281 (gravkiste-overgr); Ebbesen 1983 nr 49.

IIB. 40: Ø. Vandet, Sjørslev s, (130611). 1902.

$\oslash^{\star}-V$. MNBO. NM A 20129-32. Glob 1944, 282 (hellekiste); Lomborg 1973, 205 (EK); Sterum 1974, fundliste II nr 13 (kiste med indgang).

IIB. 41: Søhøj, Sjørslev s, (130611). 1903.

SS $\star^{\star}-N N V$. MNB. NM A 21156-157. Ebbesen 1983 nr 50.

IIB. 42: Bredsgårde, Ravnstrup s, Sb 84, (130810). 1886.

$\mathrm{S}^{\star}$-N. Udat. Ebbesen 1983 nr 52.

IIB. 43: Laeagergård, Vammen I, Vammen s, (130814). 1929.

VSM 6235, 6463-73. Glob 1944, 281, (gravk.-overgr)

IIB. 44: Troelstrup, Hersom s, Sb 58, (130903). 1939.

S*-N. Udat. NM B 13298-304. Ebbesen 1983 nr 54.

IIB. 45: Hersom, Hersom s, (130903).

Udat. VSM 6517.

IIB. 46: Hvilsom, Hvilsom s, Sb 69, (130905). 1953.

S*-N. Udat. Ebbesen 1983 nr 55.

IIB.47: Tågehøj, St. Torup Mark, Ulbjerg s, Sb 14 (130913).

SØ夫-NV. MNB/SN. Ebbesen 1983 nr 56.

IIB.48: Tostrup, Vester Tostrup s, Sb 88 (130916).

$\mathrm{S}^{\star}$-N. SN. Ebbesen 1983 nr 57.

IIB.49: Østerbølle, Østerbølle s, Sb 93 (130917).

$\mathrm{S}^{\star}-$ N. SN. Ebbesen 1983 nr 58.

IIB.50: Krejbjerg, Krejbjerg s, Sb 15, (131003). 1928.

SØ^_NV. SNA. SMS Ref.I 459-67. Ebbesen 1983 nr 59.

IIB.51: Sdr. Thiese, Thiese s, Sb 27, (131108). 1918.

SSV*-NNØ. MNBO. NM A 29878-80; Glob 1944, 281 (gravk.-overgr/dolkt); Lomborg 1973,205 (EK). Ebbesen 1983 nr 60.

IIB.52: Abildhøj, Viskum s, Sb 27, (131211). 1934.

VSM 6521.

IIB.53: Hviding, Vorning s, Sb 38, (131212). 1914.

$\mathrm{S}^{\star}$-N. Udat. NM j.nr 454/14. Ebbesen 1983 nr 61.

IIB.54: Holme, Dråby s, (140502). 1969.

SSØ*_NNV. MNB. KHM 42/69. 
IIB.55: Brigsted, Søvind s, Sb 18, (160508). 1894.

$\mathrm{S}^{\star}-\mathrm{N}$. SN. Oplysningerne er meget sparsomme. Kunne godt være et dyssekammer. Ebbesen 1983 nr 65.

IIB. 56: Kallerupgårde, Tåstrup s, (020207). 1937.

Med tærskelsten. Liversage 1964 note 49.

IIB.57: Bispebjerg Mølle/Galgehøj, København s, Sb 3, (020306). 1887.

SNC, NM a 6985-90. Liversage 1964, 45 note 34. Lomborg 1973, 201 (SN).

IIB.58: Marbjerg, Fløng s, (020401). 1912.

Udgravet af Kjær. Med gang/forrum, sidevægge $\mathrm{i}$ indgangsgrube. Kan ikke typebestemmes.

IIB. 59: Skedebjerggård, Himmelev s, (020405).

Med tærskelsten. Intet gravgods. Stürup i Skalk 1962/1, 10; Lomborg 1964 note 30.

IIB. 60: Ejby, Rye s, (020611). 1939.

Sjxllandsk gravkiste. Liversage 1964 note 14.

IIB. 61: Holbak Slots Ladegård, Holbæk s, Sb 14 (030303). 1896.

$\varnothing^{\star}$-V. SNB. NM A 15372-77. Müller 1902, 144-46; Lomborg 1973, 210 (SN).

IIB. 62: Tuse, Tuse s, (030713). 1954.

Sjællandsk gravkiste med smal indgang. Uvis type. Liversage 1964 note 45.

IIB. 63: Valsømagle, Haraldsted s, (040206). 1908.

SNC. Kiste med indgang. NM A 24496-97, B8937. Liversage 1964 note 53; Lomborg 1973, 201 $(\mathrm{SN})$.

IIB. 64: Ortved, Vigersted s, (040220). SNB. NM A 40000. Lomborg 1973, 204 (EK).

IIB. 65: Landsgrav, Sct. Pederlandsogn, (040313).

SS ${ }^{\star}{ }_{-N}$ NNV. Udat. NM A 20982. Glob 1944, 193, 195; Liversage 1964 note 43.

IIB. 66: Petersgård, Kallehave s, (050206). 1846.

$\div$ orient. SNB. Gravkiste. Lomborg 1973, 205 (X).

IIB. 67: Overvindinge, Sværdborg s, (050409). 1914.

$\div$ orient. Udat. Gravkiste. Liversage 1964 note 45 .

IIB. 68: Klose, Lindelse s, (090304). 1924.

$\div$ orient. Udat. Gravkiste. Langelands Museum? Liversage 1964 note 53 .

IIB.69: Slude, Frørup s, (090606). 1925.

Udgravet af Hatt. $\div$ orient. Udat. Gravkiste. Liversage 1964 note 49.

\section{Katalog IIC}

\section{Katalog over anlæg, som ikke er gravkister}

- eller ikke kan bestemmes som sådan på grund af bevaringsforholdene.

Anlæggene er tidligere angivet som gravkister eller beslægtede typer.

IIC.01: Boel, Gjerum s (100305). 1852.

SNB. NM 12342-43. Lomborg 1973, 204 (EK). Minder mest om en megalitgrav.

IIC.02: Horne Kirkegård, Horne s, (100606). 1939.

$S^{\star}$-N. SNC. NM A 38295-301. Lomborg 1973, 204 (EK). Meget forstyrret.

IIC.03: St. Tornby, Tornby s, (100615). 1885.

EK. NM 6474-85. Glob 1944, 281 (gravkiste-overgr/SN); Lomborg 1973, 205 (X).

IIC.04: Klammerihøj, Harring s, Sb 20, (110103). 1960.

NV-SØ. MNB/SN. NM A 49569-72. 
IIC.05: Volstedlund, Volsted s, (120115). 1869.

EK. NM A 767-72. Glob 1944, 198 (hellekiste-overgr/SN); Lomborg 1973, 205 (EK); Sterum 1974, 96, II nr 4.

IIC.06: Volsted Hede, Volsted s, (120115). 1887.

EKO. NM A 7093-7106. Glob 1944 (gravkiste-overgr); Lomborg 1973, 205 (EK).

IIC.07: Froer, Fræer s, (120303). 1878.

SN. NM A 3002-04. Lomborg 1973, 05 (X).

IIC.08: Grevelund Hede, Vive s, (120414).

SNA. NM A 8107-09. Lomborg 1973, 205 (X).

IIC.09: Nordligste Hestehøj, Vive s, (120414). 1933.

SNA. NM A 36459. Lomborg 1973, 204 (EK). Meget usikkert om, der har været indgang.

IIC.10: Viehøjene, Sønderholm s, (120511). 1893.

VSV^_ØNØ. SNB. NM A 11854-57. Ebbesen 1983 nr 39.

IIC.11: Ulveknold, Munkholm, Sønderup s, (120512). 1895.

EKO. VMA 1637/ FSM A760-2, 796-7. Glob 1944, 281 (gravkiste-overgr). I flg. skitse i udgraveren pastor Brummers katalog er der tale om en jættestue.

IIC.12: Astrup, Givers, Sb 36 (120805). 1890.

EKB. VMÅ 1481/ FSM A 468-85. Glob 1944, 281 (gravkiste-bundgr).

IIC.13: Toustrup, Durup s, (130201). 1878.

EKO/TRB. NM A 3178-83. Glob 1944, 281 (gravkiste). Da en af ravperlerne tydeligvis er økseformet, er det sandsynligt, at den dårligt oplyste stengrav er en megalit.

IIC.14: Tavl, Hjermind s, (130705). 1906.

SØ^-NV. NM A 22931. Lomborg 1973, 205 (EK). Antagelig en megalitgrav.

IIC.15: Asmild, Asmild s, (130801). 1834.

EKB. NM MCXXXII. Glob 1944, 281 (usikker gravkiste). Helt ubestemmelig.

IIC.16: Ejstrup, Rødding s, Sb 89, (131007). 1949.

EK/SN. NM A 44089-91. Lomborg 1973, 205 (EK). Sandsynligvis en lukket hellekiste.

IIC. 17: Hobro, Hobro s, (140703). 1858.

EK. NM 17125-29. Lomborg 1973, 205 (EK). Sterum 1974, II, 17 (ubestem).

IIC.18: Mariager, Mariager s, (140705). 1882.

SNA. NM 9245-53 og A5359-62. Lomborg 1973, 205 (EK). Lomborg 1973, 205 (EK).

IIC. 19: Gårslev, Gårslev s (170502). 1890.

NM A 9886-91. Glob 1944, 196 fig. 108. Senest Hvass 1988-89 note 14. Dette er et meget problematisk anlæg, hvortil der knytter sig stor usikkerhed. På trods af tegningens lighed med en gravkiste er der måske tale om et megalitanlæg fra tragtbægerkulturen. I graven lå stridsøksen (A9890), som er af Fredgårdetype. Det kan selvfølgelig ikke udelukkes at øksen er genfundet under enkeltgravskulturen og som en antikvitet er endt i en grav, bygget i denne periode.

IIC.20: Olshøj, Blidstrup s, (010101). 1960.

"Gravkiste« ellers ingen oplysninger i NM's arkiv.

IIC.21: Gadehøj Underup, Vejlby s, (010113).

SN B. Forssander 1936, 116; Lomborg 1973, 201 (SN). Der er tale om en lukket kiste.

IIC.22: Grase, Græese s, (010303). 1906

SN. NM A 22932-41. Lomborg 1973, 166 (SN). uvis type

IIC. 23: Sandbjerggård, Olsted s, (010511). 1886.

SNB. NM A 6873-74. Kjær 1910, 204; Lomborg 1973, 201 (SN).

IIC.24: Søsum, Stenløse s, (010605). 1905.

NM A 22361-62, B 8389. Lomborg 1973, 201 (SN). Uvist om kisten er åben eller lukket. 
IIC.25: Målov, Måløv s, (020210). 1896.

Liversage 1964 note 19 . Ubestemmelig type.

IIC.26: Hove Mark, Smørum s, (020212). 1843.

Ø-V. SN. NM 7732. Lomborg 1973, 166 (SN). Uvist om kisten er åben eller lukket.

IIC.27: Nybolle, Smørum s, (020212). 1907.

EK/SN. NM A 23320-22. Glob 1944, 282 (hellekiste-bundgr); Sterum 1974, II nr 1. Ubestemmelig gravtype.

IIC.28: Gladsaxe, Gladsakse s, (020303). 1959

Udgravet af Vebæk. Uvist om åben eller lukket. Liversage 1964 note 8, Kaul 1987, 54.

IIC.29: Kobenhavns Østerfalled, København s, (020306). 1910.

SNC. NM A 26282. Lomborg 1973, 201 (SN).

IIC.30: Skodborg, Søllerød s, (020310). 1934.

Uvis type. 3 kister under samme høj. Liversage 1964 note 12.

IIC.31: Flong, Fløng s, (020401). 1881.

SNB. NM A 5205-08. Lomborg 1973, 201 (SN). Uvist om åben eller lukket.

IIC.32: Herringslose/Hove Overdrev, Hvedstrup s, (020406). 1894.

SNC. NM A 12585-86; Kjær 1910, 204; Lomborg 1973, 201.

IIC.33: Heinstrupgård/Tågeruphøjene, Kirkerup s, (020408). 1890.

SNC. NM A 9779-81. Kjær 1910, 204; Lomborg 1973, 198 (højgrav); Liversage 1964, 41 note 9.

IIC.34: Roskilde, Roskilde landsogn s, (020410).

SNC. NM A 6376-80. Kjær 1910, 204; Lomborg 1973, 201 (SN)

IIC.35: Solrød, Solrød s, (020510). 1895.

SNB. NM B 6284-85. Lomborg 1973, 201 (SN). Uvist om åben eller lukket.

IIC.36: Roskilde, Roskilde s, (020410). 1885.

SNA. NM A 6376-80. Lomborg 1973, 201 (SN). Forssander 1936, 116 (lukket hellekiste); Liversage 1964 note 11; Lomborg 1973, 201 (SN). Uvis om åben eller lukket.

IIC.37: Aagerup, Aagerup s, (020415).

Pilespids SM 181. SN. NM A 3185. Kjær 1910, 205. Uvis type/hellekiste

IIC.38: Drøsselbjerg, Drøsselbjerg s, (030203). 1897.

SNB. NM A 16680-81. Forssander 1936, 116 (lukket); Lomborg 1973, 205 (X)

IIC.39: Grevinge, Grevinge s, (030404). 1899.

SNB. NM A 18182. Lomborg 1973, 201 (SN). Uvist om åben eller ej.

IIC. 40: Sonderup, Boeslunde s, (040301). 1895.

SNC. NM A 14726-28. Kjær 1910, 205; Lomborg 1973, 201 (SN).

IIC.41: Gamle Hestehauge, Svendborg s, (090513). 1933.

SNC. NM A 36185-86. Lomborg 1973, 204 (EK). 


\section{Noter}

1) Dronning Margrethe II's Arkæologiske Fond takkes for en økonomisk støtte, der har gjort det muligt at samle materialet samt at foretage sammenlignende studier af de stenbyggede gravkister.

Der er foretaget en primær gennemgang af både træbyggede og stenbyggede gravkister fra Jylland, hvor følgende museer og samlinger er besøgt: Nationalmuseets 1. afd. (NM); Ålborg Historiske Museum (ÅHM); Viborg Stiftsmuseum (VSM); Vendsyssel Historiske Museum, Hjørring (VHM); Morslands Historiske Museum, Nykøbing Mors (MHM); Forhistorisk Museum, Moesgård (FHM); Kulturhistorisk Museum, Randers (KHM); Regnar Pedersen, Nysum (Reg. Ped.); Vesthimmerlands Museum, Aars (VMÅ).

Indsamlingen er principielt afsluttet i 1984. Senere tilkomne fund er medtaget i det omfang, de er publiceret i AUD 1985-90.

Materialet fra de danske øer stammer kun fra litteraturen herunder AUD samt beretninger, der er indsendt til Nationalmuseet. Der er således ikke foretaget nogen systematisk gennemgang af materiale på lokalmuseerne.

Følgende Museumsinspektører og udgravningsledere takkes for tilladelse til at publicere de her fremlagte fund, samt for deres imødekommenhed og hjælpsomhed ved mine besøg: Aase Vrang og Per Noe, Morslands Historiske Museum; Jannie L. Nielsen, Erik Johansen og Peter Birkedahl, Ålborg Historiske Museum; Agner Jensen og John Simonsen, Skive Museum; Niels Sterum, Ole Scmidt, Ernst Stidsing, Martin Olesen, Randers Kulturhistoriske Museum; Niels Andersen, Forhistorisk Museum Moesgård; Jens Åge Pedersen, Gilleleje Museum; Jørgen Jacobsen og Henrik Mikkelsen, Fyns Stiftsmuseum; Per Lysdahl, Vendsyssel Historiske Museum.

En særlig tak skal rettes til forh. gårdejer Regnar Pedersen, Nysum. Han henvendte sig til forfatteren, umiddelbart efter det første fund fra Keldgården var omtalt i pressen og gjorde opmærksom på, at han havde undersøgt lignende anlæg. Tak for stor gæstfrihed og hjælpsomhed under mine gentagne besøg. Regnar Pedersen har siden skænket sin samling til Sydhimmerlands Museum i Hobro.

Mus.insp. Chr. Fischer, Silkeborg Museum og Mus.insp. Michael Lauenborg, Esbjerg Museum takkes for henvisninger til ringgrøftanlæg, udgravet af deres respektive museer.

En række personer, der har arbejdet med beslægtede emner, takkes for tilladelse til at se upublicerede arbejder samt for henvisninger og kommentarer. Det drejer sig om Mus.insp. Poul Kjærum, Forhistorisk Museum, Moesgård, Mus.insp. Mette Iversen, Viborg Stiftsmuseum, Lektor Klaus Ebbesen, Københavns Universitet, Mus.Insp. Claus Malmros, Nationalmuseets 8. afd., Mus.insp. Niels Sterum, Kulturhistorisk Museum, Randers, Mus.insp. Arne H. Andersen, Odsherreds Museum.

Tak til Tove Borre og Ørslev Kloster for enestående arbejdsperioder, der har gjort det muligt at skrive denne artikel.

2) Edderup, Sem s, Sb 43 (140709). 1974. KHM 1973/74.

3) Tvillinghøjgård, grav oh, Fausing s, Sb 2 (141002). 1972. KHM 432/72. Undersøgt af Elmer Christensen, KHM.

4) Denne afgørende iagttagelse anvendes i øvrigt som ét blandt flere af hans argumenter for at hævde, at udviklingen ved overgangen fra mellemneolitikum til senneolitikum bestemmes af enkeltgravskulturen og ikke tragtbægerkulturen. Et synspunkt, der først vandt almindelig tilslutning flere årtier senere.

5) Der henvises til Glob 1944 og Lomborg 1973, 12ff. Ingen af disse referencer dækker dog synspunkter om gravkisternes fortsatte opførelse i senneolitikum!

6) Ebbesen overtager, som ovenfor nævnt, stort set Müllers definition. Tilsyneladende på grund af orienteringen medtages følgende 7 anlæg ikke (Nærværende katalog IIA): Nr 1, 6, 9, 10, 12, 14, 57. Med kravet om, at Bøstrup-kisterne skal have »en pæreformet eller lignende grundplan" (Ebbesen 1983, 7) bortfalder følgende anlæg (katalog IIA): Nr. 4, 7, 9, 11, 12, 13, 14, 15, 16, 27, 24, 28, 38, 42, 52, 55, 56, 57, 60, 61. Lidt uforståeligt er det dog, at følgende ikke medtages:7, 8, 11, 25, 40, 47, 53 (den sidstnævnte făr dog en særlig behandling (Ebbesen 1983 note 14), uden at argumentationen er overbevisende).

Siden Ebbesen afsluttede sin materialeindsamling i 1970, er der fremkommet 8 nye fund: (Kat.IIA, 15, 24, $30,40,43,45,46$ og 49).

7) Disse udrømninger er sjældent dokumenterede. En af undtagelserne er gravkisten fra Blære (IIA.40), hvor der i modsætning til de fleste andre undersøgelser også er frilagt et større område uden for indgangen. Her fandtes resterne af gravgodset fra den primære begravelse i en vifte foran indgangen (Fabech 1988, 64).

8) Højen havde to primære grave A4 og A6 (det opgravede undergrundsmateriale fra gravene var lagt direkte på det gamle muldlag og senere dækket af højen). Begge er fyldskiftegrave og orienteret $\varnothing-\mathrm{V}$. A6 er uden sten og oldsager. A4 havde i bunden en række støttesten i hver side. Disse sten har antagelig støttet en bulkiste. I graven fandtes 18 ravperler.

Perifert i højen fandtes en lille stensat, lukket hellekiste uden dæksten (A5) med 2 ravperler. Denne grav er antagelig dækket af en sekundær højudvidelse, der ikke kan være tidligere end det træbyggede kammer. Senere end højudvidelsen er anlagt en grav (A2) med 3 ravperler, dækket af et trækulslag. Øverst i højfylden, uden påviselig grav, fandtes et svajet lerkar med bølgebåndsornamentik. Endelig fandtes øverst i højens centrum en urnebrandgrube med brændte knogler og keramik fra førromersk jernalder per I (A7). 
9) K-3627 og 3628. Venligst meddelt af museumsinspektør C. Malmros i brev af 25/5 1981.

10) Stridsøksen er $18,0 \mathrm{~cm}$ lang og $0,6 \mathrm{~cm}$ bred. Skafthullet har en diameter på $2,8 \mathrm{~cm}$. (Glob 1944, 36). I det følgende benævnes stridsøkserne efter Globs typologi.

Flintøksen er fremstillet af sort flint. Den er 12,9 cm lang, ægbredden er 4,2 cm, nakkebredden er $2,8 \mathrm{~cm}$, og nakke-tykkelsen er $1,7 \mathrm{~cm}$.

Den lille ravring har en indre og ydre diameter på 1,4-1,7 cm og 2,4-2,6 cm. Tværsnittet er nærmest rektangulært.

Den store ring er mere plump og har henholdsvis en indre og ydre diameter på 1,7 cm og 4,3-4,7 cm. Tværsnittet er uregelmæssigt cirkulært.

11) Prøven fra væggen K-3627: $4010 \pm 85$ f. 1950. (kal.: 2550-2490). Den bestod af eg og lind. Prøven fra gulvlaget K-3628: $4030 \pm 85$ f. 1950. Den bestod af eg, lind og el. Dateringsresultaterne er venligst meddelt af H. Tauber i brev af 19/11 1981. Kalibreringerne er beregnet efter Radiocarbon 1993 (Stuiver \& Pearson 1993; Pearson \& Stuiver 1993) og meddelt af Uffe Rahbek i brev af 18/3 1994.

12) K-4269: $4100 \pm 85$ f. 1950 (kal.: 2620) og K-4270: $3990 \pm 60$ f. 1950 (kal.: 2470). Venligst meddelt af museumsinspektør H. Tauber i brev af 17/11-1984. Kalibreringerne er beregnet efter Radiocarbon 1993 (Stuiver \& Pearson 1993; Pearson \& Stuiver 1993) og meddelt af Uffe Rahbek i brev af 18/3 1994.

13) Ravringen har en ydre diameter på $1,8 \mathrm{~cm}$ og en indre på $0,8 \mathrm{~cm}$. Den har rundt tværsnit.

14) Ca. $30 \mathrm{~cm}$ over kammergulvet fandtes en $2,5 \mathrm{~cm}$ lang, fliget pilespids. Den er antagelig kommet ned i højen efter, at kammeret er styrtet sammen. Den er af en slank form, som hører hjemme i den senere del af senneolitikum eller i ældre bronzealder.

15) Karret er et svajet bæger med en randdiameter på $15 \mathrm{~cm}$. Højden kan bestemmes til at være mindst 11,5 $\mathrm{cm}$. Karret har en let fortykket udfaldende rand, en næsten lodret overdel og smal skulder lige over bugknækket. Overdelen er ornamenteret med et enkelt vinkelbånd, udført med en kam med 4 tænder. Over og under dette bånd fandtes en række af lodrette indstik. Ved bugknækket er anbragt små lodrette lister med ca. 10 centimeters mellemrum. Karrets underdel er ornamenteret med tætliggende vinkelbånd, fremstillet med en lignende, evt. den samme kam som overdelens vinkelbånd.

16) Karret er et $11,6 \mathrm{~cm}$ højt svajet bæger, ornamenteret med tosnoet snor og bundter af modstillede skrålinier.

17) Karret er et $8,5 \mathrm{~cm}$ højt svajet bæger. Det er ornamenteret med 3 bælter af skråstreger, der danner et sildebensmønster. Skønt formen må svare til type C1, er der dog træk, der peger på type I.

18) K 4022: $3910 \pm 85$ f. 1950 (kal.: 2450-2410). Resultatet er meddelt af H. Tauber i brev af 5/7 1983. Kalibreringerne er beregnet efter Radiocarbon 1993 (Stuiver \& Pearson 1993; Pearson \& Stuiver 1993) og meddelt af Uffe Rahbek i brev af 18/3 1994.

19) K-4023: $3920 \pm 85$ f. 1950 (kal.: 2460-2410). Resultatet er venligst meddelt af $H$. Tauber $i$ brev af 5/7 1983. Kalibreringerne er beregnet efter Radiocarbon 1993 (Stuiver \& Pearson 1993; Pearson \& Stuiver 1993) og meddelt af Uffe Rahbek i brev af 18/3 1994.

20) K 3472: $3980 \pm 85$ f. 1950 (kal.: 2470). Resultatet er meddelt af H. Tauber i brev af 12/11 1980. Kalibreringerne er beregnet efter Radiocarbon 1993 (Stuiver \& Pearson 1993; Pearson \& Stuiver 1993) og meddelt af Uffe Rahbek i brev af 18/3 1994.

21) Højen er udover gravkisten anlagt over 2 paralleltliggende fyldskiftegrave, vest for gravkisten. Den ene af gravene indeholdt et ravstykke. Omkring alle 3 grave er der dokumenteret opgravet undergrundsmateriale liggende på den oprindelige muldoverflade.

22) Lerkarret er 5,3 cm højt og har en randdiameter på 8,2-8,5 cm. Mag.art. L. Winzentz har bestemt karret, som hørende til hendes gruppe III,4 (Winzentz 1977) og gør opmærksom på, at kun 2 kar inden for denne gruppe kan dateres nærmere. Det drejer sig om et ornamenteret kar fra Jættestuen Jordhøj (Kjærum 1970, fig. 14:5) og et uornamenteret kar fra gravkisten i Blære (kat IIA.43) (Fabech 1988,63 fig. 14). Begge dateres til senneolitikum A. Det første på grundlag af ornamentikken. Det andet på grund af stratigrafien.

23) Keramikken i grøften dateres derimod til tidlig mellemneolitisk tragtbægerkultur. Den må opfattes som et tilfældig indblandet ældre materiale, måske er den samtidig med den stenfrie grube.

24) En undtagelse blandt de stenbyggede gravkister er Kobberup (IIA.48), hvor gravens gang og højfoden synes at være forbundet med en træbygget forgård (mundtlig oplysning fra overinsp. P. Kjærum).

25) Type A defineres som gravkister, med cirkulære, ovale eller pære- eller trapezformede gravrum. Det vil sige, at kammerets største bredde findes ud for kammerets bageste tredjedel. Forskellen mellem største og mindste bredde er mindst $10 \%$ af gravkammerets længde.

26) Gravkister af type B defineres som gravkister med gravrum, hvor den bageste del (mindst halvdelen af gravrummets samlede længde) er rektangulær. Det vil sige, at forskellen mellem den mindste og største bredde er mindre end $0,1 \mathrm{~m}$ pr. meter i den bageste del af kammeret. Den forreste del af kammeret kan bestå af en væg, der ligger i forlængelse af den ene af den bageste dels vægge, mens den anden danner en stump vinkel med den bageste dels væg. Herved bliver det samlede gravrum femkantet. I det sekskantede kammer danner begge vægge i den forreste del stumpe vinkler med vægge i den bageste del. 
Ved et trapezformet forrum forstås et forrum, hvor forskellen mellem største og mindste bredde er mindst $0,1 \mathrm{~m}$ pr. meter af forrummets længde.

27) Type C: Defineres som gravkister med rektangulært eller tøndeformet gravrum og rektangulært forrum.

28) Type D: Defineres som gravkister med rektangulært gravrum og ingen forrum.

29) Type E: Defineres som gravkister med rektangulært eller tøndeformet gravrum uden gang.

30) Det kan i enkelte tilfælde være vanskeligt at skelne mellem type A2a og B1a. Disse typer har dog samme datering, så konsekvenserne er overskuelige. Det kan også være problematisk at placere anlæg med en gang, der danner en stump vinkel med kammerets længderetning, f. eks IIA.84.

31) Kombinationen af træ og sten som byggemateriale kendes i Danmark fra Kobberup (Kat IIA.48), hvor der foran et stenbygget kammer med gang fandtes en træbygget "forgård», der forbandt gangen med højperiferien.

32) Indgangen skiller sig ud fra de øvrige gravkister. Adskillelsen mellem gravrum og forrum er en stenpladevæg forsynet med et hul. Skogsbokisterne er desuden væsentligt længere end andre gravkister

33) Der må dog tages forbehold over for regionale forskelle. Således er de bornholmske og skånske hustomter fra senneolitikum af en særlig type. Men fra disse områder kendes heller ikke gravkister for i senneolitikum.

\section{LITTERATUR}

Aaby, B. 1985: Norddjurslands landskabsudvikling gennem 7000 år. Belyst ved pollenanalyse og bestemmelse af støvindhold i højmosetørv. Fortidsminder 1985. Antikvariske Studier 7.

Adamsen, C. \& K. Ebbesen. 1986: Stridsoksetid i Sydskandinavien. Beretning fra et symposium 28-30.X.1985i Vejle. Arkæologiske Skrifter 1. København.

Albrethsen, S.E. \& J. Street-Jensen. 1964: En højgruppe ved Vojens. Aarbøger for Nordisk Oldkyndighed 1964.

Albrethsen, S.E (red.): Antikvariske studier tilegnet Knud Thorvildsen på 70-årsdagen 18. december 1977.

Andersen, H.H. 1979: To grave fra tidlig enkeltgravskultur i Sarup. Fynske Minder 1978.

Andersen, S.H. 1983: Kalvø - a coastal Site of the Single Grave Culture. Journal of Danish Archaeology 2.

Asingh, P. 1988: Diverhøj - A Complex Burial Mound and a Neolithic Settlement. Journal of Danish Archaeo$\log \gamma 6,1987$.

AUD = Arkaologiske Udgravninger i Danmark 1984-1992

Becker, C.J. 1936: Enkeltgravskulturen på de danske øer. Aarbøger for nordisk oldkyndighed. 1936.

Becker, C.J. 1950: Den grubekeramiske kultur i Danmark. Aarbøger for nordisk oldkyndighed. 1950, s. $153 \mathrm{ff}$.

Becker, C.J. 1953: Stenaldergrav fra Gabøl med stridsøkser af jysk og svensk type. Kuml 1953.

Becker, C.J. 1957: Nogle keramikfund fra det jyske enkeltgravsområde. SMYA 58, s. 4-22.

Becker, C.J. 1973: En neolitisk gravkiste fra Bjerreby på Tåsinge. Fynske Minder 1974, s. 89-95.

Behrens, H. \& E. Schröter. 1980: Siedlungen und Gräber der Trichterbecherkultur und Schnurkeramik bei Halle (Saale). Berlin.

Boas, N. A. 1983: Egehøj. A Settlement from the Early Bronze Age in East Jutland. Journal of Danish Archaeo$\log \gamma$ 2, s. 90-101.

Brøndsted, J. 1939: Danmarks Oldtid I. 1. udgave.

Brøndsted, J. 1957: Danmarks Oldtid I. 2. udgave.

Buckvaldek, M. \& C. Strahm. 1992: Die kontinentaleuropäischen Gruppen der Kultur mit Schnurkeramik. Schnurkeramik-symposium 1990. Praha 1992.

Damm, C. 1993: The Single Grave Culture - Ethnic Migration or social Construction? Journal of Danish Archaeology 10, 1991, s. $199 \mathrm{ff}$.

Danmarks langste udgravning. Arkcoologi på naturgassens vej 1979-86. Rigsantikvarens Arkæologiske Sekretariat (red.). København 1987.

Ebbesen, K. 1980: Statussymboler fra stenalderen. Museer $i$ Viborg amt, s. 114-119.

Ebbesen, K. 1980: Romdrup. En stenaldergrav genanvendt i jernalderen. Kuml, s. 159-168.

Ebbesen, K. 1983: Flintcelts from Single-Grave Burials and Hoards on the Jutlandic Peninsula. Acta Archaologica 53.1982.

Ebbesen, K. 1985: Nordjyske gravkister med indgang. Bøstrupkisterne. Aarbøger for Nordisk Oldkyndighed. 1983.

Fabech, C. 1988: Storstenskisten fra Blære. Kuml. 1986.

Fischer 1956: Die Gräber der Steinzeit im Saalegebiet.

Forssander, J.E. 1936: Der Ostskandinavische Norden wärend der ältesten Metalzeit Europas.

van Giffen, A.E. 1930: Die Bauart der Einzelgräber.

van Giffen A.E., M. Addink-Samplonius \& W. Glasbergen. 1971: Een Grafheuvel te Putten (GLD). Helinium 11, s. 105-123.

Glob, P.V. 1945: Studier over den jyske Enkeltgravskultur. Aarbøger for nordisk oldkyndighed 1944.

Hansen, M. 1980: En enkeltgravshøj fra Kjeldgården, Aars. Fra Himmerland og Kjar herred 1980, s. 91-100.

Hansen, M. 1982: Vesthimmerlands Flyveplads. Single-Grave Mounds. Journal of Danish Archaeology 1, s. $169 f$. 
Hansen, M. 1986a: Enkeltgravskulturens gravmateriale fra Sydvestjylland. I: Adamsen \& Ebbesen (red.) 1986.

Hansen, M. 1986b: Enkeltgravskulturens Bopladsfund fra Vesthimmerland og Ribe-området. I: Adamsen \& Ebbesen (red.) 1986.

Hansen, M \& H: Rostholm. 1993 : Grave fra enkeltgravstid og senneolitikum. I: Hvass, S \& B. Storgaard. (red.) 1993.

Hvass, L. 1992: Die Einzelgrabkultur in Jütland, Dänemark. I: Buchvaldek, M. \& C. Strahm, (red.) 1992.

Hvass, L \& S. 1990: Et gravkammer fra enkeltgravskulturen. Kuml 1988-89.

Hvass, S. 1978: A House of the Single-Grave Culture excavated at Vorbasse in Central Jutland. Acta Archaeologica. 48. 1977, s. 219-32.

Hvass, S. \& B. Storgaard. 1993: Da Klinger i Muld ... 25 års arkaologi i Danmark.

Jensen, J. Aa. 1973: Bopladsen Myrhøj. 3 hustomter med klokkebægerkeramik. Kuml 1972.

Johansen, E. 1977: Alstrup-højen. Enkeltgrave med skeletter. I: Albrethsen (red.) 1977.

Johansen, E. \& E. Hasselgren. 1984: Sandflugtens velsignelser. Skalk 1984, 1, s. 8- 11.

Johansson, B.O.H. 1961: Stenåldershällkistor från svensk-norska gränslandskab. Tor VII.

Jørgensen, E. 1977: Hagebrogård - Vroue - Koldkur. Arkæologiske Studier 4.

Jørgensen, E. 1985: Brydningstid. Skalk 1985/2.

Jørgensen, E. 1985: To gravhøje ved Hjordkær i Sønderjylland. Om særprægede senneolitiske gravanlæg. Kuml 1984.

Jørgensen, L. 1984: Et gravanlæg fra enkeltgravskulturen. Museerne i Viborg amt 12.

Kjær, H. 1910: Gravkister fra Stenalderens Slutningstid. Aarboger for Nordisk Oldkyndighed 1910.

Kjærum, P. 1967: Trækisten i Stenkisten. Skalk 1967/1, s. 3-7.

Kjærum, P. 1970: Jættestuen Jordhøj. Kuml 1969.

Kretzsch. 1955: Drei Schnurkeramische Grabanlagen auf den »Grossen Stein« Bei Seifartsdorf, Landkreis Eisenberg. Thüringen. Alt-Thüringen. Erster Band 1953/54, s. 182-209.

Langballe, H. 1985: Foulum huset - tempel eller bolig. Museerne $i$ Viborg amt 13.

Lauenborg, M. 1980: Kjærsing II. En højgruppe fra enkeltgravstid. Mark og Montre 1980, s. 7-17.

Liversage, D. 1964: En hellekiste ved Gerdrup, Københavns amt. Aarbøger for Nordisk Oldkyndighed. 1964.

Lomborg, E. 1973: Die Flintdolche Dänemarks. Nordiske Fortidsminder B1.

Madsen, B. \& A. Berg Nielsen. 1987: Arkæologiske fund. Kulturhistorisk Museum, Randers. Virksomhed og resultater 1986 .

Madsen, O. 1990a: Gantrup. En enkeltgravshøj med ringgrøft og grav med dødehus. Kuml 1988-89.

Madsen, O. 1990b: Grønlund. En høj med kammergrav og andre grave fra bronzealderen. Kuml 1988-89, 97-116.

Malmer, M.P. 1962: Jungneolitische Studien.

Malmros, C. \& H. Tauber. 1977: Kulstof-14 dateringer af dansk enkeltgravskultur. Aarboger for Nordisk Oldkyndighed. 1975.

Mathias, W. 1974: Kataloge zur Mitteldeutschen Schnurkeramik IV. Südhartz-Unstrut-Gebiet.

Müller, S. 1897: Vor oldtid.

Müller, S. 1898: De jyske Enkeltgrave fra Stenalderen. Aarboger for nordisk Oldkyndighed. 1898.

Müller, S. 1902: Flintdolkene i den nordiske stenalder. Nordiske Fortidsminder 1,4.

Müller, S. 1911: Vendsysselstudier II. Sten- og Bronzealderens mindesmærker og fund. Aarbeger for nordisk Oldkyndighed, s. 276-320

Müller, S. 1913: Sønderjyllands Stenalder. Aarbøger for nordisk Oldkyndighed, s. 169-322.

Noe, P. 1971: Frigivet. En enkeltgravshøjs storhed og forfald. Museerne i Viborg amt 1, s. 44-47.

Noe, P. 1973: Endnu en dobbeltgrav. Museerne $i$ Viborg amt 3.

Nordman, C.A. 1917: Jættestuer i Danmark. Nordiske Fortidsminder II,2.

Nordmann, C.A. 1935: The Megalithic Culture of Northern Europe.

Pedersen, H. 1881: Om Stenalderens Gravformer i Danmark og deres indbyrdes Tidsforhold. Aarboger for Nordisk Oldkyndighed 1881, s. 299-368.

Pedersen, J.-Aa. 1993: Egedal. En senneolitisk gravplads ved Arresø. Arkacologi i Frederiksborg Amt 1983-1993. Frederiksborg Amts Museumsråd.

Rosenberg, G. 1929: Nye Jættestuefund. Aarboger for Nordisk Oldkyndighed 1929, s. $245 \mathrm{ff}$.

Rostholm, H. 1982: Oldtiden på Herningegnen.

Rostholm, H. 1982: A Grave Complex of the Early Single Grave Culture at Skarrild Overby, Central Jutland. Journal of Danish Archaeology 1.

Schiellerup, P.S. 1992: St.Valbyvej - et senneolitisk højkompleks ved Himmelev, nord for Roskilde. Aarbeger for Nordisk Oldkyndighed 1991.

Schwantes, G. 1939: Geschichte Schleswig-Holstein I. Vorgeschichte. 1. udgave 1939.

Siemen, P. 1980: Enkeltgravshøje i Redsted sogn på Mors. Museerne i Viborg amt 10, s. 102-113.

Simonsen, J. 1981: Bolig eller dødehus. Museerne $i$ Viborg amt 11.

Simonsen, J. 1983: A Late Neolithic House Site at Tastum, Northwestern Jutland. Journal of Danish Archaeo$\log \gamma 2$ s. 81-89. 
Simonsen, J. 1986: Nogle nordvestjyske bopladsfund fra enkeltgravskulturen. I: Adamsen \& Ebbesen (red.) 1986.

Simonsen, J. 1987: Settlements from the Single Grave Culture in NW-Jutland. Journal of Danish Archaeology $5,1986$.

Sterum, N. 1974: Hellekister i sen jysk enkeltgravskultur. Aarbøger for Nordisk Oldkyndighed 1974, s. 61-103.

Struwe, K. 1955: Die Einzelgrabkultur in Schleswig-Holstein.

Strömberg, M. 1952: Die Bestattungsformen in Schonen während des Spätneolithikums. Meddelanden från Lunds Universitets Historiska Museum.

Strømberg, M. 1975: Studien zu einem Gräberfeld in Löderup. Acta Arch. Lund ser.in. $8^{\circ}$ No 10, s. 66.

Thrane, H. 1967: Stenalders fladmarksgrave under en bronzealderhøj ved Gadbjerg. Aarbøger for Nordisk Oldkyndighed 1967, s. 27-90.

Vebæk, C. L. 1957: Gjerrild. Nationalmuseets Arbejdsmark 1957, 75ff.

Vellev, J. \& B. Jensen.: Erobrerfolkets børn. Skalk 1971/1.

Vellev, J. 1975: Skringstrup-pladsen. Nye betragtninger. Hikuin 2, s. 67-74.

Wincentz, L. 1977: Upubliceret hovedfagsspeciale. Institut for Forhistorisk Arkæologi, Moesgård. Aarhus Universitet. 


\section{Wooden burial cists from the Single Grave Culture and the Late Neolithic}

The wooden burial cists that have turned up mostly in recent years are here given their first collective treatment. In the introduction are given the views of various authors, especially Müller, Forssander, Glob, Lomborg, and Ebbesen (notes 1-7).

The term burial cist is understood here as referring to any funerary cist with opening at one end dating from the Single Crave Culture or the Late Neolithic. They could have the components, burial chamber, antechamber, and passage.

The burial chamber is the innermost part of the cist, separated from the rest by a sillstone, a row of stones, or some similar construction. It is frequently indicated by a footing trench in which the wooden constructional elements originally stood.

The passage is the name applied to the outermost part of the structure if this is narrower than the burial chamber.

The antechamber is the part of the cist intervening between the passage and the burial chamber. If there is no passage, then the antechamber is the part of the cist in front of the burial chamber.

The following 11 wooden burial cists are described: Vesthimmerlands landing field barrou, 3, type A2a, cat.IA.12. (figs. 2-6; notes 8-11).

Drenghoj, type A2a cat. IA.()1. (fig. 7; note 12). Kragehej, type B2, cat. IA.()8. (figs. 13-15, notes 15-18). Volstrup, type 132, cat. IA.()7. (fig. 16, note 19). Keldgård barrou 2, type B2, cat. IA.13. (fig. 1). Sonder Tranders, type C2, cat. IA.()2. (figs. 17-18; note 2()). Vesthimmerlands landing ficld barrow 2, type 1)2, cat. IA.11. (figs. 19-22; notes 21.22). Toftclund $I$, type I)1, cat. IA.21 (Fig. 1.15). Rold, type I)2, cat. IA.()4. (Fig. 1.12). Kovhej, type E, cat. IA.(05. (Fig. 1.11; note 23).

The cists fall into four categories according to their principles of construction:

1: Burial cists sunk into the original ground surface, having four corner posts but no footing trench (IA.2, 29).

2: Burial cists whose walling stood against the outer side of the footing trench and was packed by stones in the middle of the trench.
The reason for this construction is certainly that the cists were inserted secondarily into earlier barrows and the walling was placed against the sides of the excavation (IA.12). IA.19 may be related, but the field observations lack detail.

3: In four cases there were definite postholes in the trench (IA.()6, 21, 22, 27 and I13.05 and ()6, and also in a cist that could not be typedetermined (I13.()(6)). In none of these cases were traces of planks found along the sides of the trench. The posts were in one case supported by stones (IA.21).

4: However the commonest wall construction was a plank wall standing along the inner side of the trench, which was observed in eight cases (IA.()1, ()3, ()7, ()8, ()9, 10, 11, 13, 14, 17) and an uncertain case (IA.()5). In some of these the construction was supported by stones (IA.()1, ()5, 14).

There was evidence of roofing in two cases (IA.1() and 12), and it appears to have been flat. A flat roof would result in a structure somewhat resembling a stone burial cist.

There is evidence of mode of access in some of the cases where the cist was surrounded in its time of use by the earth of the mound, The cases were Vesthimmerlands landing field barrows 1 and 3 (IA.1() and 12) and Keldgården barrow 3 (IA.14). In all cases access had been from the surface of the mound downwards to the cist, and not inwards from the edge of the barrow (note 2.5).

The wooden burial cists fall from their plan and structure into six main types (note 31 ):

Type A: Cists with round, pear-shaped, or trapeziform burial chamber. The type can have antechamber or passage. Six variants can be distinguished (note 2.5).

Type B: Cists with a pentagonal or hexagonal burial chamber, or cists with a rectangular to barrel-shaped burial chamber and a trapeziform antechamber. This type can have a passage. Three variants can be distinguished (note 26).

Type C: Burial cists with rectangular or barrelshaped burial chamber and rectangular ante- 
chamber. The type may have passage. Two variants can be distinguished (note 27).

Ty'pe D: Burial cists with rectangular or barrelshaped burial chamber. The entrance is narrower than the chamber and there can be a passage. Two variants can be distinguished (note 28).

Type E: Burial cists with rectangular or barrelshaped burial chamber with neither passage nor antechamber (notes 29-3()).

The dating of the types is based on grave goods and on radiometric age determinations.

Type A can be dated to the younger Undergrave and older (iround-grave period; but variant $A 1$ is dated to the younger Undergrave period while A2-3 are dated to early in the Ground-grave period (battle axe types $F$ and (i).

Type $\mathrm{B}$ can be dated to the later part of the older (iround-grave period (battle axe type $\mathrm{H}$ ).

Type C can be dated to the younger Groundgrave period.

Type 1)1 can be dated to the Uppergrave period.

Type I)2 can be dated to the Uppergrave period and Late Neolithic A.

Type E can be dated to Late Neolithic A.

The datings have been compared with the stone cists given in the table, fig. 21, which shows that none of the type-determinate stone cists with grave goods had equipment older than the period to which they would be assigned in the above typological dating system. The C.-14 datings are shown in fig. 22.

The orientations of the different types as defined above vary considerably. The entrances of the oldest type (A1) face west, The entrances of types A2-3, B, C, and 1) face predominantly SE or $S$, while the entrance of type E mainly face $E$. The eastern orientation of this type is most marked on the Danish islands.
Many burial cists contemporary with the above have been found in other parts of northern and western Europe, but they are often poorly described and are therefore difficult to distinguish from earlier graves. All types excepting $\mathrm{B}$ are represented.

Type A1 is known from central Jutland and Funen. A2-A3 have their main concentration in and near Himmerland and on the Danish islands. They are also known from Holland and north and central (iermany. Type $\mathrm{B}$ is known almost exclusively from Himmerland. Types $C$ and E1 are known from the eastern Limfjord area and close to it, and from central Germany. Variant E2 is numerous on Zealand, and in the western Limfjord area, Sweden, and Germany.

From this it would seem that variant A1 originated in south l)emmark, perhaps as a development of the small ring-ditch structures called "beehive graves". Variants A2-A3 were constructed over a large part of northern Europe. Types A2 to E2 were constructed in a continuous series in the eastern Limfjord area, especially in Himmerland. At times they were known here almost exclusively, but in Late Neolithic A the eastern Limfjord area became marginal in the distribution of the cists.

From this new examination of burial cists it seems to me that Forssander's suggestion that development of the cists was inspired by the passage graves is correct (Forssander 1936, 115). This would mean that type A2a originated in Himmerland. 1)wellings from the early Single (irave Culture appear to be round, while those from the upper grave period and the Late Neolithic were rectangular. This agrees with the development of the cists and implies a parallel evolution. Only new discoveries of house remains from the ground grave period can confirm this however.

Mogens Hansen

Grindsted-Vorbasse Museum

Oversattelse: David Liversage 